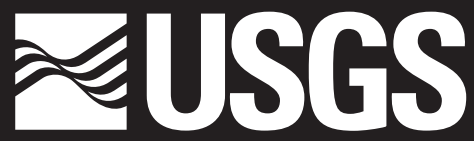

science for a changing world

Prepared in cooperation with the Upper Arkansas Water Conservancy District;

Colorado Water Conservation Board; Chaffee, Custer, and Fremont Counties; Buena Vista, Cañon City, Poncha Springs, and Salida; and Round Mountain Water and Sanitation District

\title{
Groundwater and Surface-Water Interaction and Potential for Underground Water Storage in the Buena Vista-Salida Basin, Chaffee County, Colorado, 2011
}
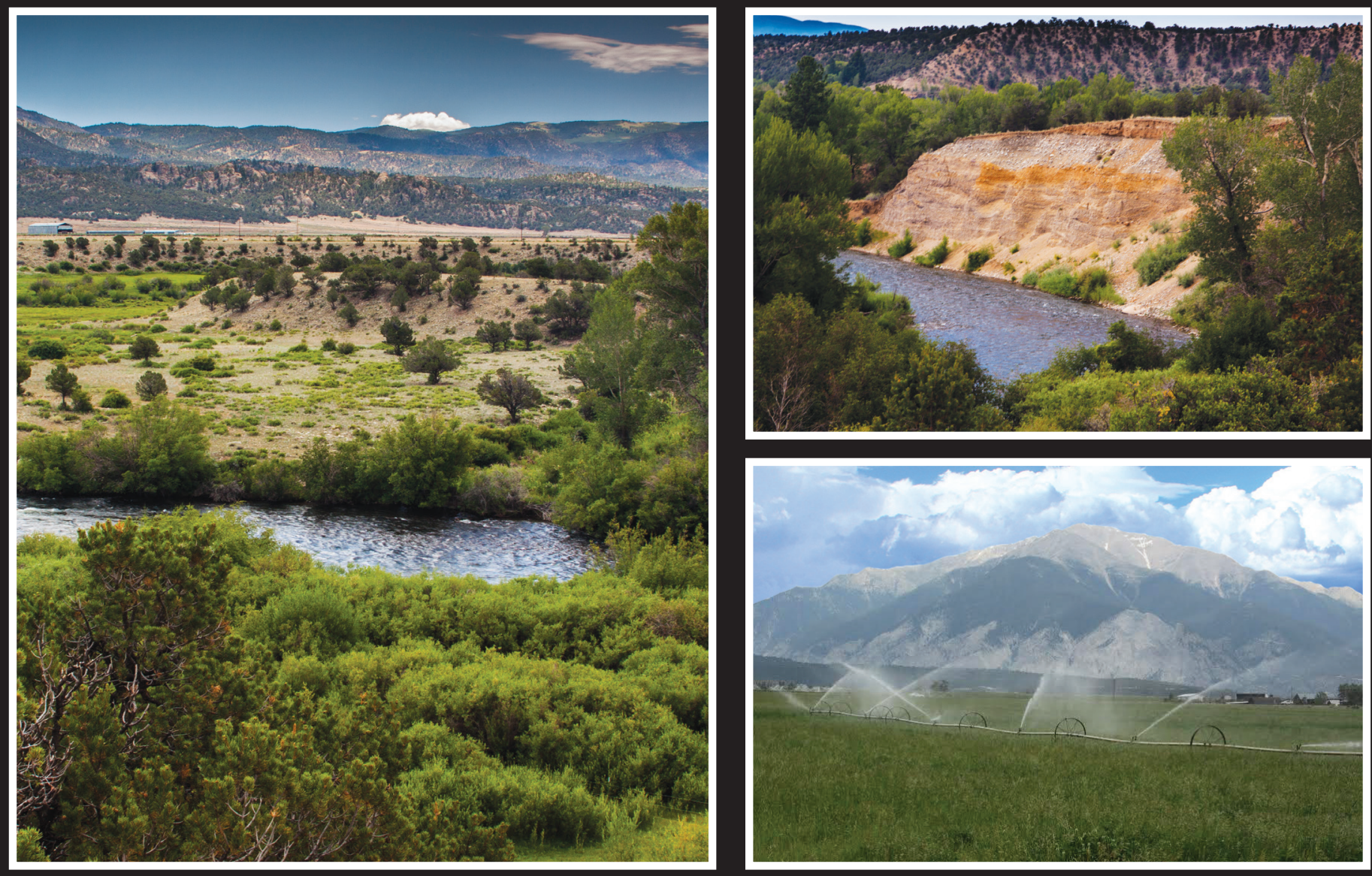

Scientific Investigations Report 2014-5095

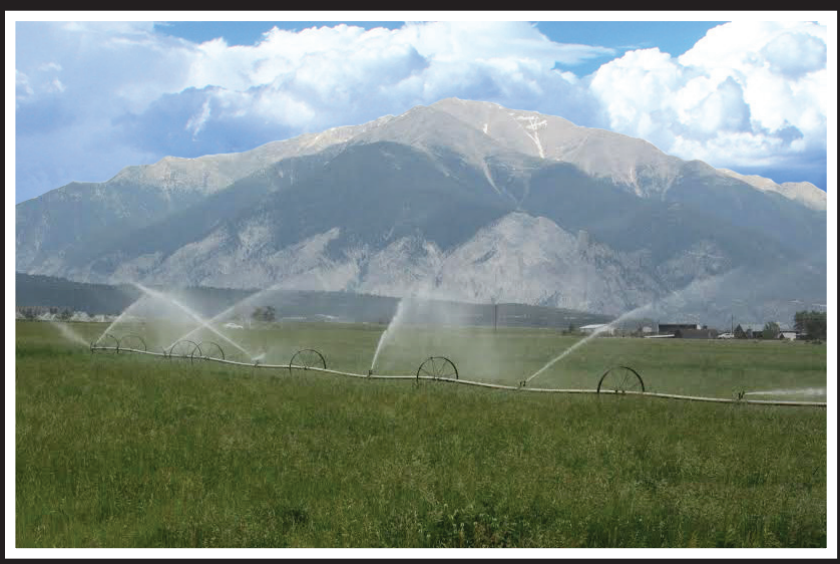


Cover. Left, Terrace deposits and Arkansas River near Johnson Village, Colorado. Photograph by Robert Stogner. Upper right, Terrace deposits and Arkansas River near Johnson Village, Colorado. Photograph by Robert Stogner. Lower right, Irrigation on terrace deposits near Johnson Village, Colorado. Photograph by Christopher Brown. 


\section{Groundwater and Surface-Water Interaction and Potential for Underground Water Storage in the Buena Vista-Salida Basin, Chaffee County, Colorado, 2011}

By Kenneth R. Watts, Tamara Ivahnenko, Robert W. Stogner, and James F. Bruce

Prepared in cooperation with the Upper Arkansas Water Conservancy District; Colorado Water Conservation Board; Chaffee, Custer, and Fremont Counties; Buena Vista, Cañon City, Poncha Springs, and Salida; and Round Mountain Water and Sanitation District

Scientific Investigations Report 2014-5095 


\title{
U.S. Department of the Interior SALLY JEWELL, Secretary
}

\section{U.S. Geological Survey Suzette M. Kimball, Acting Director}

\author{
U.S. Geological Survey, Reston, Virginia: 2014
}

For more information on the USGS - the Federal source for science about the Earth, its natural and living resources, natural hazards, and the environment, visit http://www.usgs.gov or call 1-888-ASK-USGS.

For an overview of USGS information products, including maps, imagery, and publications, visit http://www.usgs.gov/pubprod

To order this and other USGS information products, visit http://store.usgs.gov

Any use of trade, firm, or product names is for descriptive purposes only and does not imply endorsement by the U.S. Government.

Although this information product, for the most part, is in the public domain, it also may contain copyrighted materials as noted in the text. Permission to reproduce copyrighted items must be secured from the copyright owner.

Suggested citation:

Watts, K.R., Ivahnenko, Tamara, Stogner, R.W., and Bruce, J.F., 2014, Groundwater and surface-water interaction and potential for underground water storage in the Buena Vista-Salida Basin, Chaffee County, Colorado, 2011: U.S. Geological Survey Scientific Investigations Report 2014-5095, 63 p., http://dx.doi.org/10.3133/sir20145095.

ISSN 2328-0328 (online) 


\section{Contents}

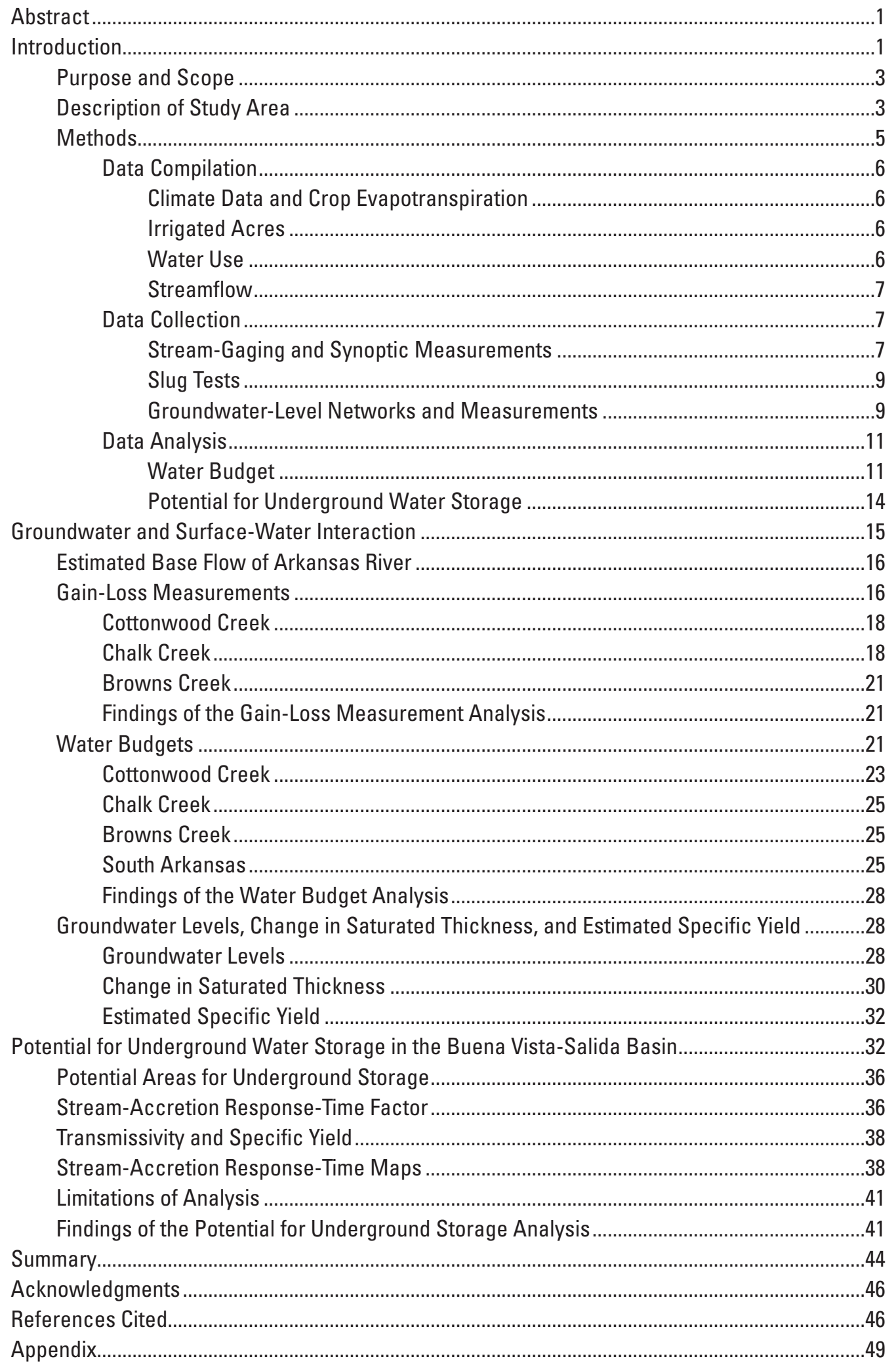




\section{Figures}

1. Map showing location of the Arkansas Headwaters Region and study area. .2

2. Map showing generalized surface geology and structure of the Buena VistaSalida Basin and vicinity, Colorado ..

3. Map showing locations of selected climate and stream-gaging stations in the Buena Vista-Salida Basin, Colorado, 2011

4. Map showing irrigated parcels in selected water-budget areas of the Buena Vista-Salida Basin, Chaffee County, Colorado, 2011. 10

5. Diagram of the hydrologic cycle for part of a watershed... 14

6. Graph showing gaged and base-flow components of streamflow of the Arkansas River near Wellsville, Colorado, 1999-2011........................................................................17

7. Map showing Cottonwood Creek synoptic, diversion, and stream-gaging sites ...............19

8. Map showing Chalk Creek synoptic, diversion, and stream-gaging sites .......................20

9. Map showing Browns Creek synoptic, diversion, and stream-gaging sites ...................22

10. Map showing groundwater monitoring wells and aquifer- and slug-test sites in the Buena Vista-Salida Basin

11. Map showing generalized altitude and configuration of potentiometric surfaces in the Buena Vista-Salida Basin during $A$, March 2011 and B, June 2011; and $C$, estimated change in saturated thickness during March through June 2011

12. Map showing selected areas within the Buena Vista-Salida Basin that may be suitable for artificial-storage-recovery projects

13. Map showing composite stream-accretion response-time factors in the Buena Vista-Salida Basin...

14. Map showing stream-accretion response-time factors for the Arkansas River in the Buena Vista-Salida Basin .

15. Map showing stream-accretion response-time factors for Browns, Chalk, and Cottonwood Creeks, and the South Arkansas River in the Buena VistaSalida Basin

1-1. Graph showing depth to and temperature of groundwater in Colorado State University Department of Civil and Environmental Engineering monitoring well 127927_01 (U.S. Geological Survey 385820106122501), 2010 through June 2011

1-2. Graph showing depth to and temperature of groundwater in Colorado State University Department of Civil and Environmental Engineering monitoring well 137911_01 (U.S. Geological Survey 385605106105701), 2010 through April 28, 2011

1-3. Graph showing depth to and temperature of groundwater in Colorado State University Department of Civil and Environmental Engineering monitoring well 137925_01 (U.S. Geological Survey 385307106095101), 2010 through June 2011

1-4. Graph showing depth to and temperature of groundwater in Colorado State University Department of Civil and Environmental Engineering monitoring well 147924_01 (U.S. Geological Survey 384911106095701), 2010 through June 2011 
1-5. Graph showing depth to and temperature of groundwater in Colorado State University Department of Civil and Environmental Engineering monitoring well 147925_01 (U.S. Geological Survey 384828106095801), 2010 through June 2011

1-6. Graph showing depth to and temperature of groundwater in Colorado State University Department of Civil and Environmental Engineering monitoring well 147832_01 (U.S. Geological Survey 384736106082501), 2010 through June 2011

1-7. Graph showing depth to and temperature of groundwater in Colorado State University Department of Civil and Environmental Engineering monitoring well 157815_01 (U.S. Geological Survey 384429106061601), 2010 through June 2011

1-8. Graph showing depth to and temperature of groundwater in Colorado State University Department of Civil and Environmental Engineering monitoring well 157823_01 (U.S. Geological Survey 384403106050801), 2010 through June 2011

1-9. Graph showing depth to and temperature of groundwater in Colorado State University Department of Civil and Environmental Engineering monitoring well 157824_01 (U.S. Geological Survey 384340106041201), 2010 through June 2011

1-10. Graph showing depth to and temperature of groundwater in Colorado State University Department of Civil and Environmental Engineering monitoring well 157826_01 (U.S. Geological Survey 384238106045001), 2010 through June 2011

1-11. Graph showing depth to and temperature of groundwater in Colorado State University Department of Civil and Environmental Engineering monitoring well 510810_01 (U.S. Geological Survey 384134106042601), 2010 through June 2011

1-12. Graph showing depth to and temperature of groundwater in Colorado State University Department of Civil and Environmental Engineering monitoring well 510808_01 (U.S. Geological Survey 384126106062901), 2010 through June 2011

1-13. Graph showing depth to and temperature of groundwater in Colorado State University Department of Civil and Environmental Engineering monitoring well 500811_01 (U.S. Geological Survey 383541106033901), 2010 through June 2011

1-14. Graph showing depth to and temperature of groundwater in Colorado State University Department of Civil and Environmental Engineering monitoring well 500813_01 (U.S. Geological Survey 383446106021701), 2010 through June 2011

1-15. Graph showing depth to and temperature of groundwater in Colorado State University Department of Civil and Environmental Engineering monitoring well 500822_02 (U.S. Geological Survey 383443106041601), March 20, 2010 through June 2011 
1-16. Graph showing depth to and temperature of groundwater in Colorado State University Department of Civil and Environmental Engineering monitoring well 500822_01 (U.S. Geological Survey 383438106043901), 2010 through June 2011

1-17. Graph showing depth to and temperature of groundwater in Colorado State University Department of Civil and Environmental Engineering monitoring well 490804_01 (U.S. Geological Survey 383117106051901), 2010 through April 28, 2011 .

\section{Tables}

1. Coefficients used for estimating groundwater pumpage by water-use type in Cottonwood, North Cottonwood, Chalk, and Browns Creeks and South Arkansas River Basins

2. Climate, stream-gaging and augmentation stations, diversion structures, and infiltration gallery in the Buena Vista-Salida Basin, 2011

3. Summary of synoptic measurements of Cottonwood, Chalk, and Browns Creeks, and average groundwater gains and losses, August 9-11, 2010, September 8-10, 2010, April 27-29, 2011, and August 23-25, 2011

4. Surface-water budgets and groundwater recharge for Cottonwood Creek Basin between Cottonwood Creek below Hot Springs and Cottonwood Creek near Buena Vista, Colorado, and North Cottonwood Creek Basin between North Cottonwood Creek at Silver Creek Trailhead and North Cottonwood Creek above CR 361, 2011

5. Surface-water budget and groundwater recharge for Chalk Creek Basin between Chalk Creek above fish hatchery and Chalk Creek near Nathrop, Colorado, 2011 .26

6. Surface-water budget and groundwater recharge for Browns Creek Basin between Browns Creek above CR 261D and Browns Creek at the mouth, 2011.

7. Surface-water budget and groundwater recharge for South Arkansas River Basin between South Arkansas below Garfield and South Arkansas below Tenassee ditch near Salida, Colorado, 2011.

8. Estimated changes in saturated thickness, water-budget estimates of groundwater recharge, and estimated specific yield in selected areas of the Buena Vista-Salida Basin, March through June 2011

9. Reported results from aquifer tests of the alluvial-outwash aquifer in the Buena Vista-Salida Basin, Chaffee County, Colorado, 1992-2008.

10. Results from instantaneous-change-in-head (slug tests) of the alluvialoutwash and basin-fill aquifers in the Buena Vista-Salida Basin, Chaffee County Colorado, 2009

1-1. Summary of synoptic measurements of Cottonwood, Chalk, and Browns Creeks and calculated gains and losses, August 9-11 and September 8-10, 2010, and April 27-29 and August 23-25, 2011

1-2. Construction details for selected wells monitored or measured during 2010 and 2011 and selected wells with slug-test results. 


\section{Conversion Factors}

Inch/Pound to SI

\begin{tabular}{|c|c|c|}
\hline Multiply & By & To obtain \\
\hline \multicolumn{3}{|c|}{ Length } \\
\hline inch (in.) & 2.54 & centimeter $(\mathrm{cm})$ \\
\hline inch (in.) & 25.4 & millimeter (mm) \\
\hline foot $(\mathrm{ft})$ & 0.3048 & meter $(\mathrm{m})$ \\
\hline mile (mi) & 1.609 & kilometer $(\mathrm{km})$ \\
\hline \multicolumn{3}{|c|}{ Area } \\
\hline acre & 0.4047 & hectare (ha) \\
\hline acre & 0.004047 & square kilometer $\left(\mathrm{km}^{2}\right)$ \\
\hline square mile $\left(\mathrm{mi}^{2}\right)$ & 259.0 & hectare (ha) \\
\hline square mile $\left(\mathrm{mi}^{2}\right)$ & 2.590 & square kilometer $\left(\mathrm{km}^{2}\right)$ \\
\hline \multicolumn{3}{|c|}{ Volume } \\
\hline acre-foot (acre-ft) & 1,233 & cubic meter $\left(\mathrm{m}^{3}\right)$ \\
\hline acre-foot (acre-ft) & 0.001233 & cubic hectometer $\left(\mathrm{hm}^{3}\right)$ \\
\hline \multicolumn{3}{|c|}{ Flow rate } \\
\hline acre-foot per year (acre-ft/yr) & 1,233 & cubic meter per year $\left(\mathrm{m}^{3} / \mathrm{yr}\right)$ \\
\hline cubic foot per second $\left(\mathrm{ft}^{3} / \mathrm{s}\right)$ & 0.02832 & cubic meter per second $\left(\mathrm{m}^{3} / \mathrm{s}\right)$ \\
\hline million gallons per day (Mgal/d) & 0.04381 & cubic meter per second $\left(\mathrm{m}^{3} / \mathrm{s}\right)$ \\
\hline inch per year (in/yr) & 25.4 & millimeter per year $(\mathrm{mm} / \mathrm{yr})$ \\
\hline \multicolumn{3}{|c|}{ Hydraulic conductivity* } \\
\hline foot per day (ft/d) & 0.3048 & meter per day $(\mathrm{m} / \mathrm{d})$ \\
\hline \multicolumn{3}{|c|}{ Gradient } \\
\hline foot per mile (ft/mi) & 0.1894 & meter per kilometer $(\mathrm{m} / \mathrm{km})$ \\
\hline \multicolumn{3}{|c|}{ Transmissivity** } \\
\hline foot squared per day $\left(\mathrm{ft}^{2} / \mathrm{d}\right)$ & 0.09290 & meter squared per day $\left(\mathrm{m}^{2} / \mathrm{d}\right)$ \\
\hline \multicolumn{3}{|c|}{ Stream-accretion response-time factor *** } \\
\hline day per square foot $\left(\mathrm{d} / \mathrm{ft}^{2}\right)$ & 10.764 & Day per square meter $\left(\mathrm{d} / \mathrm{m}^{2}\right)$ \\
\hline
\end{tabular}

Temperature in degrees Celsius $\left({ }^{\circ} \mathrm{C}\right)$ may be converted to degrees Fahrenheit $\left({ }^{\circ} \mathrm{F}\right)$ as follows:

${ }^{\circ} \mathrm{F}=\left(1.8 x^{\circ} \mathrm{C}\right)+32$

Temperature in degrees Fahrenheit $\left({ }^{\circ} \mathrm{F}\right)$ may be converted to degrees Celsius $\left({ }^{\circ} \mathrm{C}\right)$ as follows: ${ }^{\circ} \mathrm{C}=\left({ }^{\circ} \mathrm{F}-32\right) / 1.8$

Vertical coordinate information is referenced to the North American Vertical Datum of 1988 (NAVD 88).

Horizontal coordinate information is referenced to the North American Datum of 1983 (NAD 83).

Altitude, as used in this report, refers to distance above the vertical datum.

*Hydraulic conductivity: The standard unit for hydraulic conductivity is cubic foot per day per square foot $\left[\left(\mathrm{ft}^{3} / \mathrm{d}\right) / \mathrm{ft}^{2}\right]$. In this report, the mathematically reduced form, foot per day $(\mathrm{ft} / \mathrm{d})$, is used for convenience.

**Transmissivity: The standard unit for transmissivity is cubic foot per day per square foot times feet of aquifer thickness $\left[\left(\mathrm{ft}^{3} / \mathrm{d}\right) / \mathrm{ft}^{2}\right] \mathrm{ft}$. In this report, the mathematically reduced form, foot squared per day $\left(\mathrm{ft}^{2} / \mathrm{d}\right)$, is used for convenience.

*** Stream-accretion response-time factor: The stream-accretion response-time factor (saf) is equivalent to but opposite in sign to the stream depletion factor of Jenkins (1968a). It is defined as the time at which 28 percent of the volume of constant recharge at a point will have accreted to the nearest stream. 


\section{Abbreviations}

\begin{tabular}{|c|c|}
\hline ASCE & American Society of Civil Engineers \\
\hline$\Delta \mathrm{b}$ & change in saturated volume \\
\hline CDL & Cropland Data Layer \\
\hline $\operatorname{cocC}$ & Colorado Climate Center \\
\hline CoAgMet & Colorado Agricultural Meteorological Network \\
\hline CODWR & Colorado Division of Water Resources \\
\hline COPW & Colorado Parks and Wildlife \\
\hline CR & county road \\
\hline CSUDCEE & Colorado State University Department of Civil and Environmental Engineering \\
\hline CWCB & Colorado Water Conservation Board \\
\hline DEM & digital elevation model \\
\hline ET & evapotranspiration \\
\hline $\mathrm{CU}_{\mathrm{ir}}$ & irrigation requirement \\
\hline GIS & geographic information system \\
\hline ICIS-NPDES & $\begin{array}{l}\text { Integrated Compliance Information System—National Pollution Discharge } \\
\text { Elimination System }\end{array}$ \\
\hline ISDS & individual sanitary disposal systems \\
\hline NWIS & National Water Information System \\
\hline PBWW & Pueblo Board of Water Works \\
\hline PVC & polyvinyl chloride \\
\hline $0_{\mathrm{ds}}$ & downstream flow measurement \\
\hline $0_{g w}$ & groundwater gain or loss \\
\hline $0_{\text {gwp }}$ & groundwater pumpage \\
\hline $0_{\text {gwrf }}$ & return flows to groundwater \\
\hline$\Delta 0_{\text {gwr }}$ & change in groundwater recharge \\
\hline $0_{r}$ & recharge rate \\
\hline $0_{\text {rf }}$ & return flow \\
\hline $0_{\text {sa }}$ & streamflow accretion \\
\hline$\Delta 0_{\text {sf }}$ & change (gain or loss) in streamflow \\
\hline $0_{\text {swd }}$ & surface-water diversions \\
\hline$\Delta 0_{s w}$ & change in surface-water rate \\
\hline $0_{\text {us }}$ & upstream flow measurement \\
\hline Sy & specific yield \\
\hline$\Delta S_{g w}$ & change in groundwater storage \\
\hline saf & stream-accretion response-time factor \\
\hline SECWCD & Southeastern Colorado Water Conservancy District \\
\hline UAWCD & Upper Arkansas Water Conservancy District \\
\hline USDA & U.S. Department of Agriculture \\
\hline USEPA & U.S. Environmental Protection Agency \\
\hline USGS & U.S. Geological Survey \\
\hline
\end{tabular}




\title{
Groundwater and Surface-Water Interaction and Potential for Underground Water Storage in the Buena Vista-Salida Basin, Chaffee County, Colorado, 2011
}

\author{
By Kenneth R. Watts, Tamara Ivahnenko, Robert W. Stogner, and James F. Bruce
}

\begin{abstract}
By 2030, the population of the Arkansas Headwaters Region, which includes all of Chaffee and Lake Counties and parts of Custer, Fremont, and Park Counties, Colorado, is forecast to increase about 73 percent. As the region's population increases, it is anticipated that groundwater will be used to meet much of the increased demand. In September 2009, the U.S. Geological Survey, in cooperation with the Upper Arkansas Water Conservancy District and with support from the Colorado Water Conservation Board; Chaffee, Custer, and Fremont Counties; Buena Vista, Cañon City, Poncha Springs, and Salida; and Round Mountain Water and Sanitation District, began a 3-year study of groundwater and surfacewater conditions in the Buena Vista-Salida Basin. This report presents results from the study of the Buena Vista-Salida Basin including synoptic gain-loss measurements and water budgets of Cottonwood, Chalk, and Browns Creeks, changes in groundwater storage, estimates of specific yield, transmissivity and hydraulic conductivity from aquifer tests and slug tests, an evaluation of areas with potential for underground water storage, and estimates of stream-accretion response-time factors for hypothetical recharge and selected streams in the basin.
\end{abstract}

The four synoptic measurements of flow of Cottonwood, Chalk, and Browns Creeks, suggest quantifiable groundwater gains and losses in selected segments in all three perennial streams. The synoptic measurements of flow of Cottonwood and Browns Creeks suggest a seasonal variability, where positive later-irrigation season values in these creeks suggest groundwater discharge, possibly as infiltrated irrigation water The overall sum of gains and losses on Chalk Creek does not indicate a seasonal variability but indicates a gaining stream in April and August/September. Gains and losses in the measured upper segments of Chalk Creek likely are affected by the Chalk Cliffs Rearing Unit (fish hatchery).

Monthly water budgets were estimated for selected segments of five perennial streams (Cottonwood, North Cottonwood, Chalk, and Browns Creeks, and South Arkansas River) in the Buena Vista-Salida Basin for calendar year 2011. Differences between reported diversions and estimated crop irrigation requirements were used to estimate groundwater recharge in the areas irrigated by water supplied from the diversions. The amount of groundwater recharge in all the basins varied monthly; however, the greatest amount of recharge was during June and July for Cottonwood, North Cottonwood, and Chalk Creeks and South Arkansas River. The greatest amount of recharge in 2011 in Browns Creek occurred in July and August. The large seasonal fluctuations of groundwater near irrigated areas in the Buena Vista-Salida Basin indicate that the increased groundwater storage resulting from infiltration of surface-water diversions has dissipated by the following spring.

Areas within the Buena Vista-Salida Basin with the potential for underground storage were identified using geographic information system data, including topographic, geologic, and hydrologic data, excluding the mountainous areas that border the Buena Vista-Salida Basin and igneous and metamorphic rock outcrop areas. The areas that met the selection criteria for underground water storage are located on terrace deposits near the Arkansas River and adjacent to its major tributaries. The selected areas also contain much of the irrigated land within the basin; consequently, irrigation ditches and canals could provide a means of conveying water to potential recharge sites.

\section{Introduction}

Demand for water resources in the Arkansas Headwaters Region (fig. 1), which includes Chaffee and Lake Counties and parts of Custer (not shown on fig. 1; located south of Fremont County), Fremont, and Saguache Counties, Colorado, is projected to increase substantially by 2030 . The combined population of Chaffee, Lake, Custer, Fremont, Park, and Saguache Counties, is forecast to increase about 73 percent between 2000 and 2030 (Colorado Water Conservation Board, 2004). A gap (deficit) of 5,950 acre-feet (acre-ft) between supply of and demand for municipal and industrial water is projected for these counties by 2030. Because much of the population growth in these counties likely will occur outside of service areas of municipal suppliers and because surfacewater resources in the Arkansas River Basin are fully appropriated, groundwater likely will be used to meet increased demands for domestic supplies. 

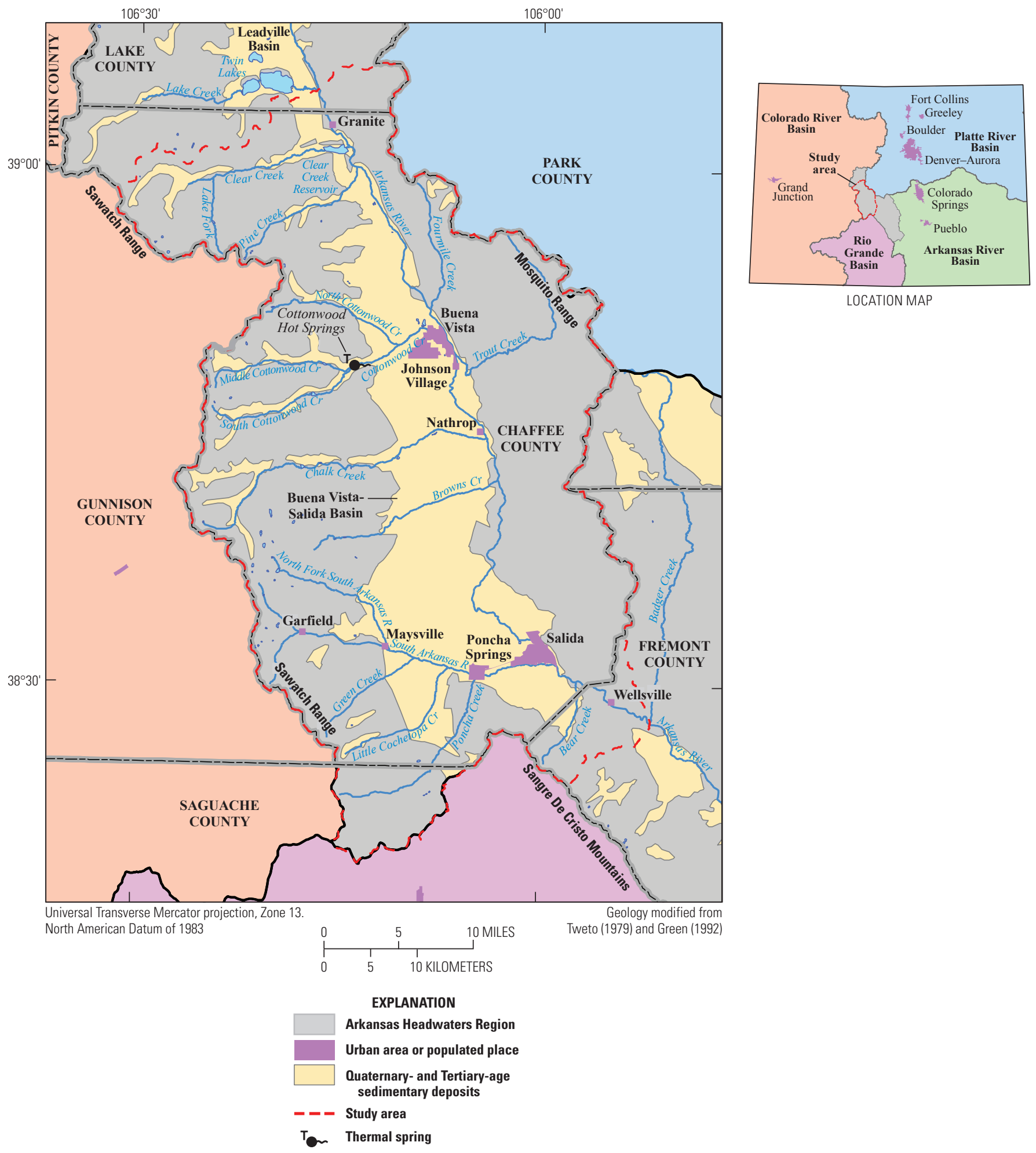

Figure 1. Location of the Arkansas Headwaters Region and study area. 
There also is a need to increase water storage within the Arkansas River Basin and a growing interest in storing water underground. A regional study of the Arkansas River and Platte River Basins ranked the alluvial deposits between Buena Vista and Salida as one of the top five areas in the Arkansas River Basin with potential for development of underground storage (Colorado Water Conservation Board, 2007). Where unsaturated, the alluvial deposits between Buena Vista and Salida have an estimated storage capacity of more than 2.2 million acre-ft (Colorado Water Conservation Board, 2007).

In September 2009, the U.S. Geological Survey (USGS), in cooperation with the Upper Arkansas Water Conservancy District (UAWCD), began a 3-year study of groundwater and surface-water conditions in the Buena Vista-Salida Basin. The study also was supported by the Colorado Water Conservation Board (CWCB); Chaffee, Custer, and Fremont Counties; Buena Vista, Cañon City, Poncha Springs, and Salida; and Round Mountain Water and Sanitation District. The objectives of this study were to characterize stream-aquifer interactions and evaluate the potential for underground water storage in the Buena Vista-Salida Basin.

\section{Purpose and Scope}

The purpose of this report is to present results from this study of groundwater and surface-water interaction and potential for underground water storage including identification of gaining and losing segments of selected tributaries, water budgets for selected areas for 2011, results from hydraulic testing of the alluvial-outwash and basin-fill aquifers, identification of areas with hydrologic characteristics suitable for development of underground water-storage projects, and estimates of streamaccretion response-time factors for the alluvial-outwash aquifer.

In addition to existing streamgages in the study area, nine temporary streamgages were installed on tributaries of the Arkansas River and operated seasonally during mid-April through mid-October of 2010 and 2011. During 2010 and 2011, synoptic discharge measurements were used to identify gaining and losing segments of selected tributary streams. Water budgets for selected tributary stream basins during 2011 were estimated using streamflow, climate, diversion, and geospatial data. Maps of groundwater-level surfaces were prepared from measurements from two monitoring networks, one measured by Colorado State University and the other measured for this study. Seasonal changes in groundwater storage during 2011 were estimated from differences between groundwater-level surfaces. Analysis of slug tests and reported results from aquifer tests were used to define hydraulic properties of the alluvial-outwash and basin-fill aquifers. Specific yield of the alluvial-outwash aquifer was estimated by comparing seasonal changes in groundwater-level surfaces with water-budget estimates of groundwater recharge in selected areas. Areas with available underground storage capacity in the Buena Vista-Salida Basin were identified using a geographic information system (GIS) and selection criteria. Stream-accretion response-time factors of the alluvial-outwash aquifer to hypothetical recharge for underground storage were estimated for the Arkansas River and selected perennial tributaries.

\section{Description of Study Area}

The study area is the watershed that drains to the Arkansas River between Granite and Wellsville, Colo. (fig. 1). The watershed is about 1,172 square miles $\left(\mathrm{mi}^{2}\right)$ in extent and primarily is in Chaffee County but also includes small parts of Fremont, Lake, and Saguache Counties (fig. 1). The primary focus of the study is the Buena Vista-Salida Basin, a 250- $\mathrm{mi}^{2}$ area in the valley between the Mosquito and Sawatch Ranges that is underlain by Quaternary-age alluvial and glacial deposits and Tertiary-age basin-fill deposits.

The Buena Vista-Salida Basin is one of three structural basins in the Arkansas Headwaters Region (fig. 1) with substantial groundwater in storage and potential for additional groundwater storage. The Leadville Basin in Lake County, to the north of the Buena Vista-Salida Basin (fig. 1), and the Wet Mountain Valley, 20 to 60 miles (mi) to the southeast of the southern end of the Buena Vista-Salida Basin (not shown in fig. 1) in Custer and Fremont Counties (Crouch and others, 1984), are the other structural basins in the Headwaters Region. Uplift of the Sawatch and Mosquito Ranges formed a down-faulted structural basin, referred to by Tweto and Case (1972) as the "upper Arkansas Valley graben." Differences in movement along the bounding faults of the graben resulted in a down-faulted structural basin that is deepest on its western side. There are two distinct structural basins in the upper Arkansas Valley graben, the Buena Vista-Salida and Leadville Basins. The upper Arkansas Valley graben narrows to the north of the study area and bedrock separates the Quaternaryand Tertiary-age deposits in the Buena Vista-Salida Basin from similar deposits in the Leadville Basin. The Quaternaryand Tertiary-age deposits are connected hydraulically with the Arkansas River and its tributaries (Watts, 2005).

Rocks in the Buena Vista-Salida structural basin range in geologic age from Precambrian to Quaternary. Bedrock is exposed on the up-thrown sides of the faults that bound the structural basin (fig. 2). The bedrock includes intrusive igneous, volcanic, and sedimentary rocks of Precambrian, Paleozoic, and Cenozoic ages. The basin-fill deposits, the Tertiary-age Dry Union Formation (Tweto, 1961), overlie bedrock in the Buena Vista-Salida Basin (Crouch and others, 1984). Quaternary-age alluvial and glacial deposits overlie the basin-fill deposits or bedrock on about two-thirds of the valley floor in the study area (fig. 2). The undifferentiated glacial deposits, as mapped by Tweto (1979), consist of outwash deposits and till. The outwash deposits, which were deposited by melt water in front of glaciers, are relatively permeable bouldery sand and gravel deposits with lenses of silts and clays. Glacial till, which is a nonstratified heterogeneous mixture of sediment sizes (clay through boulders) deposited 


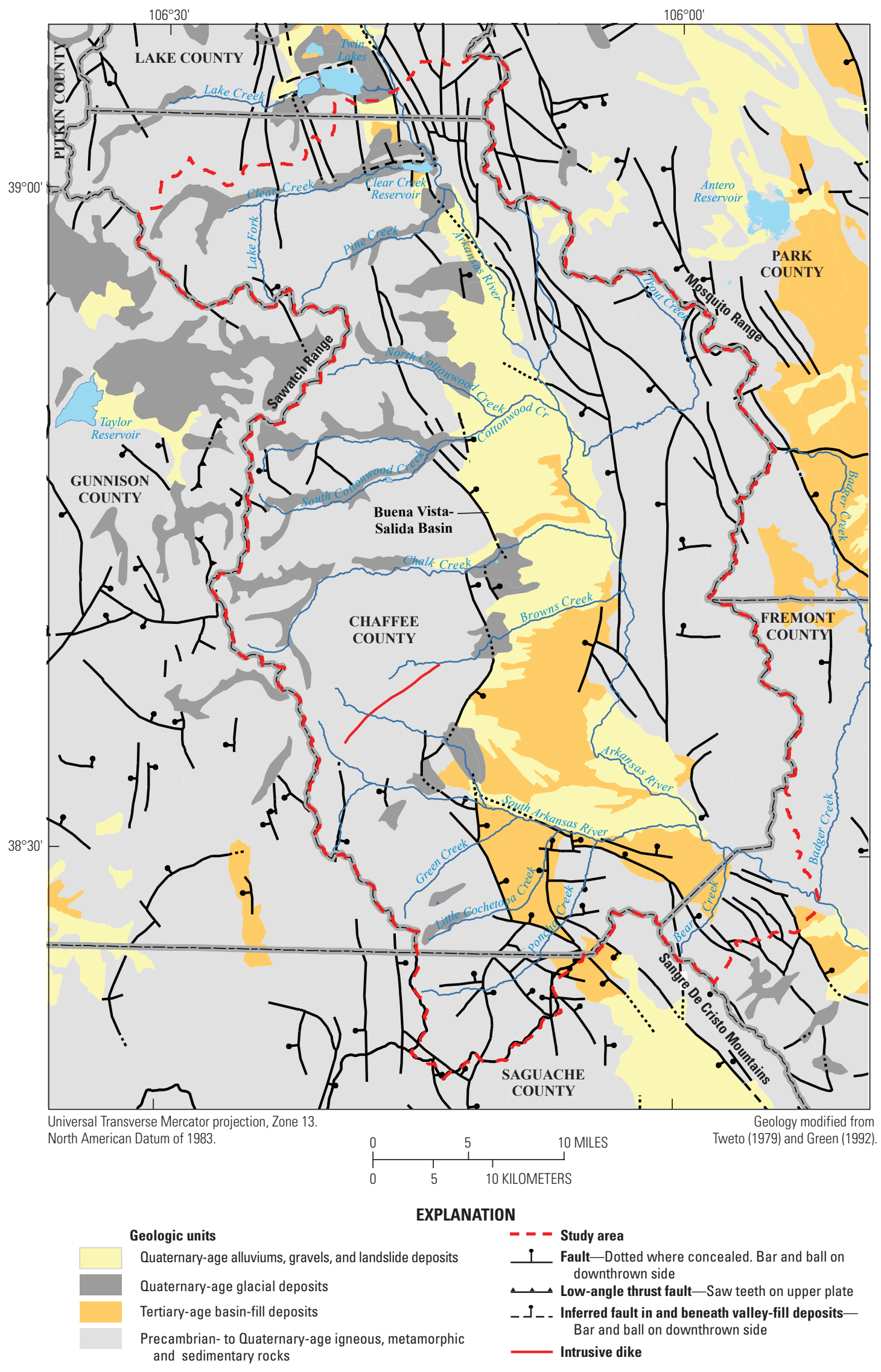

Figure 2. Generalized surface geology and structure of the Buena Vista-Salida Basin and vicinity, Colorado. 
directly by glaciers, generally is less permeable than the glacial outwash and occurs primarily in the mountain valleys west of the basin and to a limited extent along the mountain front on the western side of the Buena Vista-Salida Basin.

The principal aquifers in the Buena Vista-Salida Basin consist of alluvial-outwash and basin-fill deposits, which are referred to as the alluvial-outwash and basin-fill aquifers (Watts, 2005). The water table in the Buena Vista-Salida Basin responds to seasonal and long-term changes in streamflow and surface-water diversions, which are the primary sources of groundwater recharge. The depth to water table commonly is less than 25 feet (ft) below land surface in the floodplains of the Arkansas River and its perennial tributaries. The estimated depth to the water table may be greater than $300 \mathrm{ft}$ below land surface near some stream divides and beneath alluvial-fan deposits along the mountain front on the western side of the basin (Watts, 2005). The alluvial-outwash and basin-fill deposits in the Arkansas Headwaters Region (fig. 1) supply groundwater to more than 7,700 water-supply wells, including 4,352 domestic wells, 2,802 household-use-only wells, 352 commercial wells, 159 stock wells, 80 irrigation wells, 47 municipal wells, and 7 industrial wells, and a few wells for other uses (Colorado Division of Water Resources, 2012).

The main source of surface water into the Buena VistaSalida Basin is snowmelt runoff from the mountainous areas surrounding the basin and the Arkansas River Basin upstream from the study area. The climate of the Buena Vista-Salida Basin is semiarid with annual afternoon humidity generally less than 50 percent (Buena Vista City Data, 2011). Average monthly maximum temperature during the summer in Buena Vista (1899-2010) ranged from about 76 to 81 degrees Fahrenheit $\left({ }^{\circ} \mathrm{F}\right)$ and average monthly minimum temperatures during the winter ranged from about 10 to $20^{\circ} \mathrm{F}$ (Western Regional Climate Center, 2011). The mountains surrounding the Buena Vista-Salida Basin affect the local climate and water supply, primarily through differences in precipitation. During 1961-2011 precipitation at Buena Vista averaged about 10 inches per year (in/yr), whereas the Sawatch Range west of the Buena Vista-Salida Basin received as much as 30 to $40 \mathrm{in} / \mathrm{yr}$, primarily as snow (Western Regional Climate Center, 2011).

Runoff of snowmelt from the Sawatch Range into the Buena Vista-Salida Basin is the primary source of groundwater recharge in the study area. Most groundwater recharge occurs in areas in which surface water is diverted for irrigation of crops and pasture (Watts, 2005). Infiltration of surface water, where streams flow across alluvial and outwash deposits, also is a source of groundwater recharge. Groundwater is recharged by infiltration of streamflow where streams flow across the alluvial, glacial, and basin-fill deposits near the mountain front, but generally groundwater discharges to streams in areas farther downstream. Precipitation on areas between streams may provide a small amount of recharge but generally is insufficient to meet evapotranspiration (evaporation and transpiration) demand. During drought years, when runoff is below normal and surface water is limited or not available for diversion, groundwater recharge likely is minimal. Groundwater discharges to the Arkansas and South Arkansas Rivers, on the eastern side and near the southern end of the study basin, respectively, and along parts of tributary streams (Watts, 2005).

A large part of the total land area within the Buena Vista-Salida Basin is managed by Federal, State, and local agencies. Land in about 79 percent of the 649,508 acres in Chaffee County is managed by the Forest Service and Bureau of Land Management; an additional 3 percent of the area is managed by the Colorado State Land Board, Colorado Parks and Wildlife (COPW), and the Department of Corrections; and 18 percent of the land is privately owned (Seidl, 2007). Of the nonmunicipal privately owned land, about 10,700 acres are irrigated cropland and 97,400 acres are farm and ranchland (National Agricultural Statistics Service, 2010).

Based on estimates for Chaffee County, combined groundwater withdrawals and surface-water diversions for irrigation (crop and golf course), municipal (public) supply, self-supplied domestic, livestock, and mining during 2005 in the Buena Vista-Salida Basin totaled about 106 million gallons per day (Mgal/d) or about 119,000 acre-ft/yr (Ivahnenko and Flynn, 2010). Diversions for irrigation accounted for 97.8 percent of the water withdrawn within Chaffee County, and only an estimated 0.02 percent of the water for crop irrigation was from groundwater withdrawals. Withdrawals for public supply were an estimated $1.69 \mathrm{Mgal} / \mathrm{d}$ or about $1,890 \mathrm{acre}-\mathrm{ft} / \mathrm{yr}$, which is equivalent to about 1.6 percent of estimated withdrawals in Chaffee County. Self-supplied withdrawals for domestic use are considered to be from groundwater sources and are estimated to equal about 0.3 percent of the total withdrawals in the county (Ivahnenko and Flynn, 2010). The population in Chaffee County was estimated to be 16,970 in 2005 and is projected to increase to 27,589 by 2030 (Colorado Division of Local Government, 2011). The increase in population likely will be supplied by groundwater. Groundwater from alluvial-outwash and basin-fill aquifers in the study area (fig. 1) supply groundwater to more than 4,600 watersupply wells, including an estimated 2,831 domestic wells, 1,457 household-use-only wells, 226 commercial wells, 41 stock wells, 37 irrigation wells, 31 municipal wells, 4 industrial wells, and 2 wells for other uses (Colorado Division of Water Resources, 2012).

\section{Methods}

Data used in this study were compiled from several sources: the Colorado Agricultural Meteorological Network (CoAgMet) (Colorado State University, 2011), Colorado State University Department of Civil and Environmental Engineering (CSUDCEE), the Colorado Division of Water Resources (CODWR), the UAWCD, the U.S. Department of Agriculture (USDA), and the USGS. Data collected during this study included streamflow, hydraulic properties of aquifers, and groundwater levels. 
Groundwater and Surface-Water Interaction and Potential for Underground Water Storage, Buena Vista-Salida Basin, Colo.

\section{Data Compilation}

A number of sources, Federal, State, local, and academic, were contacted either directly or through agency Web sites for the data required for water budget and groundwater analyses. This section presents descriptions of data and data sources for climate, Chaffee County irrigated acres, water use, and streamflow.

\section{Climate Data and Crop Evapotranspiration}

During this study, two CoAgMet stations, one in Buena Vista (BNV01) and the other near Salida (SLD01) (fig. 3), were installed to provide daily crop-water use or evapotranspiration (ET) reports that can be used by local irrigators and water-resource agencies (Colorado State University, 2011). Station BNV01 is sponsored by the UAWCD, COPW, the Southeastern Colorado Water Conservancy District (SECWCD), and the Pueblo Board of Water Works (PBWW); and station SLD01 is sponsored by UAWCD, Glen Evert (landowner), the SECWCD, and the PBWW (Colorado State University, 2011). Station BNV01 is located in an area managed by the COPW and the Fremont Conservation District, and station SLD01 is located on private property. Station descriptions are available at the CoAgMet Web site http://ccc.atmos.colostate.edu/ coagmet/station_index.php. Station BNV01 began collecting data during October 2010 and station SLD01during July 2010. Both stations were operational during the latter part of the 2010 and all of the 2011 growing seasons (April through October). Monthly potential ET values were calculated from a daily reference ET using the American Society of Civil Engineers (ASCE) daily ET equation (American Society of Civil Engineers, 2005) and applying a coefficient to estimate alfalfa ET. The alfalfa ET coefficient (Allen and Wright, 2002) varies during the growth cycle of alfalfa and hay from a low of 0.5 at "green up" to 1.0 as a plant matures. A second coefficient (ranging from 0.3 to 1.0 ) is applied to the crop after the first harvest ("cutting") and a third coefficient (ranging from 0.3 to 0.58 ) is applied after the second harvest, as alfalfa enters dormancy in the fall. A green-up date of April 1, 2011, for hay and alfalfa, and number (generally two) and timing (June 20 and August 8) of cuttings during the growing season were provided by growers in the Buena Vista-Salida area (Chaffee County hay growers: Terry Scanga, Chris Nachtriabe, John Scanga, Andrew Richardson, and Albert Egleston, oral commun., 2012). Monthly crop irrigation requirements $\left(\mathrm{CU}_{\mathrm{ir}}\right)$ were calculated from the crop potential ET from the Buena Vista and Salida stations by subtracting the monthly effective precipitation amounts collected at each CoAgMet station. The ASCE daily ET equation does not include precipitation in the calculation; therefore, to correctly calculate the $\mathrm{CU}_{\mathrm{ir}}$, additional water provided to the crops as precipitation must be subtracted. Precipitation totals for March through October 2011 for Buena Vista and Salida were 5.52 and 2.82 inches, respectively.

\section{Irrigated Acres}

The irrigated acreage in the study area for the year 2011 was determined using the GIS dataset, based on areas digitized from Chaffee County 2011 orthoimagery quadrangles (U.S. Department of Agriculture, 2011). Digitized irrigated acres were reviewed and compared to a draft version of digitized and field-checked irrigated acres by the CODWR (Chris Brown, GIS Program Manager, Colorado Water Resources Division, written commun., 2011) and determined to be comparable with a few corrections. Seventy-seven acres digitized for this study were removed from the dataset after the CODWR review, because these acres likely are either subirrigated, meaning that the zone of saturation is within the root zone of crops, or may not have a surface-water diversion associated with them. Digitized irrigated areas in the Cottonwood, Chalk, and Browns Creeks, and South Arkansas River Basins total about 8,832 acres (fig. 4). These irrigated acres also include the farm and ranchland areas managed by the Colorado Department of Corrections and the greens of the two golf courses in the study area, but do not include ET from riparian phreatophytes.

Irrigated acres by crop type were determined by analysis of the 2011 USDA's Cropland Data Layer (CDL) (National Agricultural Statistics Service, 2012). The CDL dataset not only includes crop types such as alfalfa, other hay, oats, corn, and wheat, but also contains information on urban, barren, and open water areas, grass and shrub lands, and riparian and forested land covers. This dataset, however, is not a GIS coverage, and crop acres from the CDL for each Arkansas River tributary had to be converted from 30 by 30 meter pixels (Saeid Tadayon, U.S. Geological Survey, written commun., 2011) to a GIS coverage. The CDL was used only to identify crop type (alfalfa or other hay) in irrigated parcels in the study area. Irrigated acreage identified from the CDL, as converted pixels, was not used in this study because the CDL estimates of total acreage by crop type were considered too high (Kurt Jones, Chaffee County Colorado State University Extension Agent, oral commun., 2012).

\section{Water Use}

Water withdrawal and diversion data for Chaffee County for 2011 were compiled for groundwater and surface-water diversions for all major water-withdrawal categories (irrigation, municipal, industrial, commercial, aquaculture, and mining). Reported diversions by wells and from streams in the study area were downloaded from the CODWR database (Colorado Division of Water Resources, 2011). Municipal water-withdrawal data were provided by the towns of Buena Vista (Roy Gertson, Buena Vista Water, written commun., 2011) and Salida (Lonnie Oversole, Salida Water Department, written commun., 2011). Return-flow data from municipal wastewater treatment plants, commercial, industrial, and aquiculture facilities were downloaded from the U.S. Environmental Protection Agency (USEPA) Integrated Compliance Information System-National 
Pollution Discharge Elimination System (ICIS-NPDES) (U.S. Environmental Protection Agency, 2011). Coefficients of domestic self-supplied groundwater withdrawals were calculated from municipal domestic deliveries for the towns of Buena Vista (Roy Gertson, Buena Vista Water, written commun., 2011) and Salida (Lonnie Oversole, Salida Water Department, written commun., 2011).

Groundwater withdrawals and return flows were estimated based on the number of permitted wells located in the parts of the Cottonwood, North Cottonwood, Chalk, and Browns Creeks, and South Arkansas River Basins where Quaternary-age alluvial and glacial deposits and Tertiary-age basin-fill deposits are at the surface (fig. 2). Latitude and longitude coordinates of permitted wells, as listed in the CODWR HydroBase database (available at http://water.state.co.us/ DataMaps/DataSearch/Pages/DataSearch.aspx\#bulkdata), were used to assign wells to each basin. Withdrawal coefficients by use (commercial, domestic, household use only, industrial, irrigation, municipal, and stock) for Cottonwood, North Cottonwood, Chalk, and Browns (combined) Creeks and South Arkansas River Basins were based on metered withdrawals of wells of each water-use type in each basin. The withdrawal coefficients and the number of wells in each study basin are listed in table 1. Withdrawals by stock wells in all basins were estimated using an annual coefficient of 1.35 acre-ft per well (Colorado Division of Water Resources, 2013a). Pumpage data for 2011 from the CODWR HydroBase database for municipal, commercial, irrigation, or industrial wells were used where available. It was assumed that all permitted domestic and household-use-only wells withdrew water in 2011 for the full year, regardless if the well was for a partial year residence. Return flow to groundwater for indoor domestic use was assumed to equal 90 percent of withdrawals. Van Slyke and Simpson (1974) estimated that consumptive use of groundwater withdrawn for indoor domestic use in Colorado was about 10 percent of withdrawals with 90 percent returning to the water table as infiltration from nonevaporative individual sanitary disposal systems (ISDS). The 90-percent return flow was calculated directly for household use only wells, where water from these wells, as per the permit, should have no outdoor water use. A return flow rate coefficient for domestic wells, where outdoor garden and lawn application up to 1 acre is included in the well permit, required a separate calculation for flows through the ISDS. A coefficient was calculated based on per capita water use of 101 gallons per day per person calculated from municipal domestic deliveries for the towns of Buena Vista (Roy Gertson, Buena Vista Water, written commun., 2011) and Salida (Lonnie Oversole, Salida Water Department, written commun., 2011). Converting the 101 gallons per capita to acre-ft resulted in a coefficient of 0.00031 acre-ft per day, and multiplying this coefficient by 2.5 people per household (and well) is 0.00078 acre-ft per day. Average indoor water use estimated for the 2.5-person household for a month is 0.0236 acre-ft, and the estimated average monthly 90 -percent return flow is 0.021 acre-ft; this return flow coefficient is used for all domestic wells, which include partial year residences, to account for return flow from the ISDS (table 1). A 90-percent return flow rate also was assumed for groundwater withdrawals by commercial and industrial wells. Return flows of groundwater withdrawn for municipal use by the Cities of Buena Vista and Salida were included in wastewater return flows to the main-stem Arkansas River.

\section{Streamflow}

Data from streamgages operated by the CODWR, UAWCD, and USGS were used in this study (fig. 3, table 2). Daily discharge data were retrieved for study-area streamgages from the CODWR (http://cdss.state.co.us/onlineTools/Pages/ StreamflowStations.aspx), UAWCD (http://uawcd.com/ water_resources.php), and USGS (http://waterdata.usgs.gov/ co/nwis/) for January 1 through December 31, 2011. In addition, monthly summaries of streamflow were retrieved from the CODWR Web site for study-area streamgages for 1999 through 2011.

\section{Data Collection}

Data collection for this study included measurement of streamflow, installation and operation of seasonal streamgages, conducting slug tests of monitoring and selected domestic wells, and measurement of groundwater levels in selected wells. Synoptic (gain-loss) measurements were made for three tributaries of the Arkansas River. The following section describes methods of data collection used for this study.

\section{Stream-Gaging and Synoptic Measurements}

Measurements of streamflow and computation of mean daily discharge (streamflow) were done in accordance with standard USGS procedures (Rantz and others, 1982). Measurements of instantaneous streamflow were made throughout the study period at stream cross sections in the vicinity of streamgages and synoptic measurement sites that had the most even cross-sectional distribution of streamflow. Measurements of streamflow at streamgages were used to develop stage-discharge relations (rating curves) and used to compute continuous streamflow, based on the stream stage recorded by submersible transducers at the seasonal streamgage sites. Mean daily discharge values for the seasonal streamgage sites are available from the USGS Southeast Colorado Water Science Center at Pueblo, Colo. The stream-gaging network for this study includes seven gages operated by the CODWR, four gages operated by the UAWCD, and nine seasonal gages operated by the USGS during 2010-11 (fig. 3, table 2).

Synoptic streamflow measurements (gain-loss measurements) can be used to estimate the net rate of flow between a stream and a hydraulically connected aquifer and was used to identify gaining or losing stream segments. Streamflow into and out of a segment are assumed to be steady before and during the measurements and for a period greater than or equal to the travel time between the upstream and 


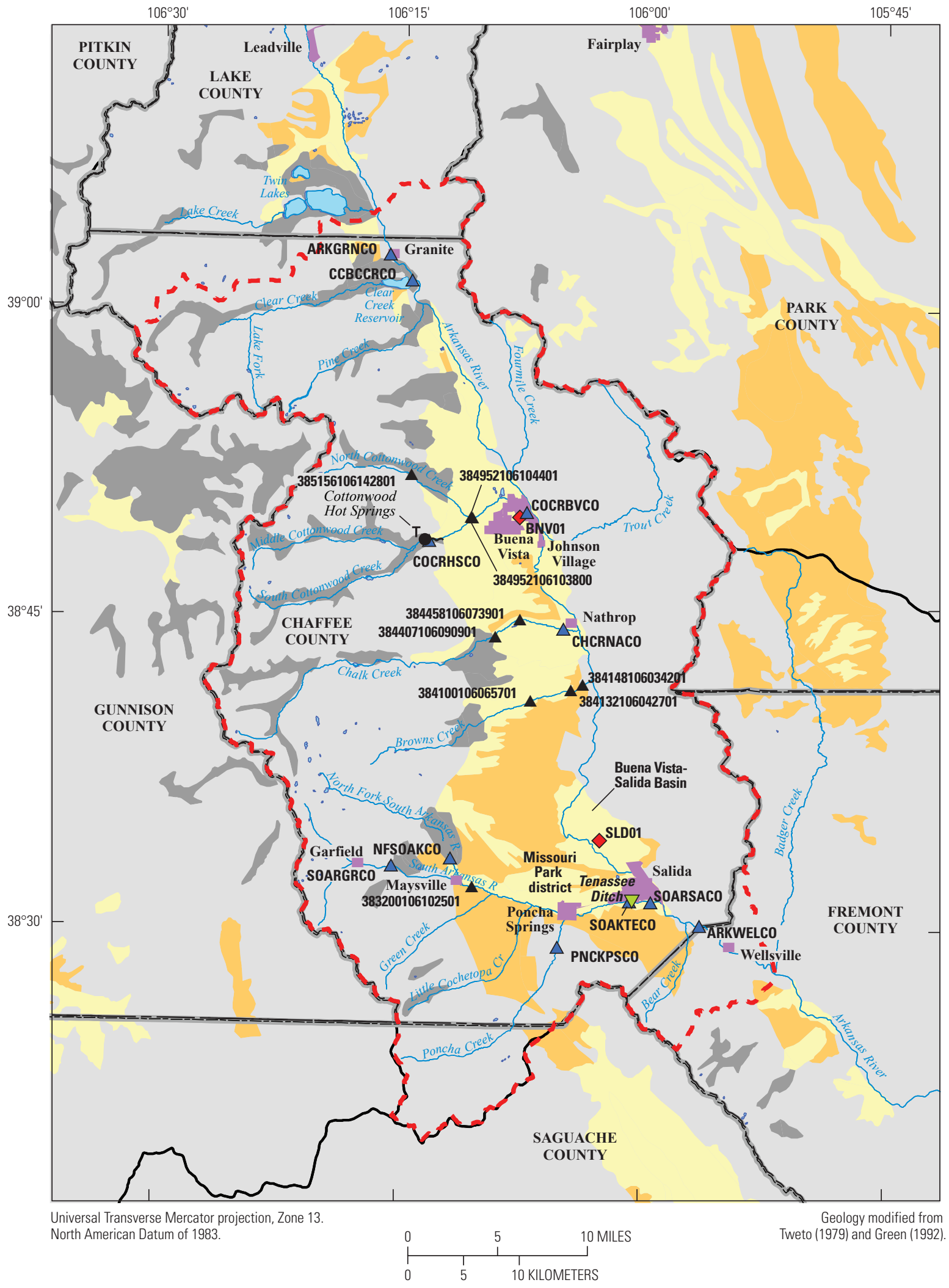

Figure 3. Locations of selected climate and stream-gaging stations in the Buena Vista-Salida Basin, Colorado, 2011. 


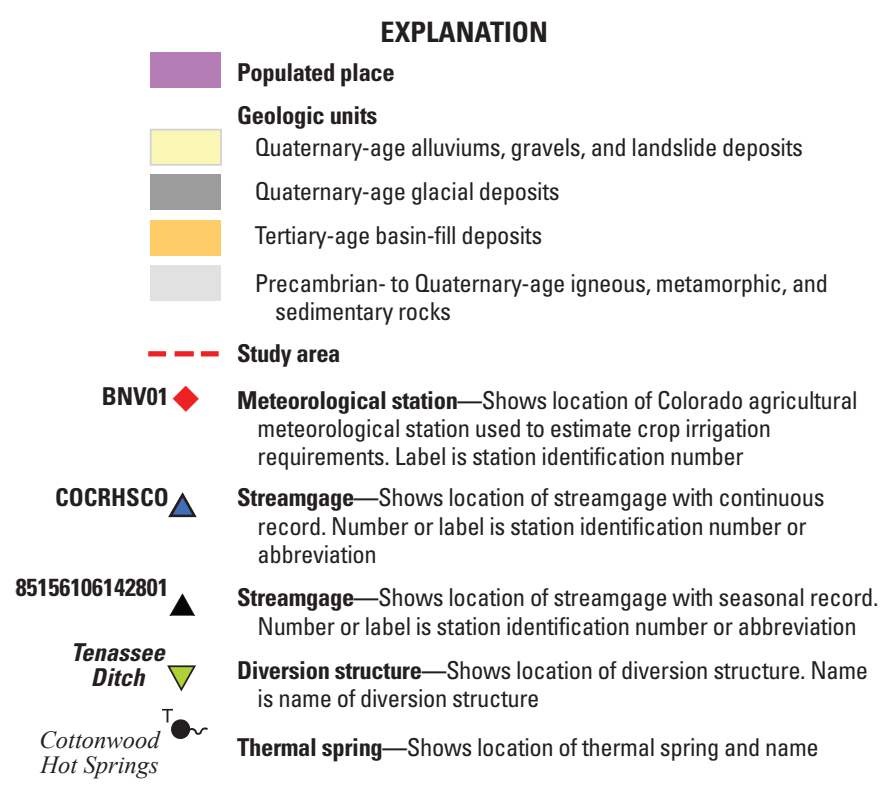

downstream measurement sites. Additionally, all diversions from and return flows to the stream are assumed to be steady and known. When possible, surface-water diversions and return flows within a stream segment were measured. Because diversion structures are private property, when permission to measure a diversion structure was not granted, reported daily diversions from the CODWR were used in gain-loss calculations. To reduce measurement bias, streamflow, diversions, and return flow measurements were made consecutively at different times of the day by different field parties, using different equipment.

The net difference in streamflow between an upstream site and a downstream site, or the net gain from or loss to groundwater, within a segment is calculated through equation 1, which includes net inflow (the parenthetical term on the right-hand side of equation 1):

$$
Q_{g w}+\text { errors }=Q_{d s}-\left(Q_{u s}-Q_{s w d}\right)
$$

where

$Q_{g w} \quad$ is the net gain from or loss to groundwater,

$Q_{d s}$ is the measured outflow at the downstream site,

$Q_{u s} \quad$ is the upstream flow measurement, and

$Q_{\text {swd }}$ is the surface-water diversions.

The net gain from or loss to groundwater $\left(Q_{g w}\right)$ also includes the sum of the errors in the other budget components. Standard errors for discharge measurements of streamflow, diversions, and return flows range from about 3 to 6 percent for measurements with generally normal measuring conditions (Turnipseed and Sauer, 2010), but standard errors for discharge measurements may be greater than 6 percent, if measuring conditions are not normal. Computed net gains or losses of streamflow are not definitive when they are less than or equal to measurement errors.
Synoptic streamflow (gain-loss) measurements were conducted four times on Cottonwood, Chalk, and Browns Creeks. The objective of the synoptic measurements was to determine the net accretion (gain) to or depletion (loss) of streamflow between measurement sites. In addition to multiple streamflow measurements at several sites on each stream, diversions from and return flows to streams were measured where site access to the diversion was granted. The net difference in streamflow between an upstream site and a downstream site, after adjustment for diversions and return flows, is assumed to equal net flow between the aquifer and stream within a segment and indicates stream segments that are gaining or losing streamflow. Instantaneous stream discharge was measured in accordance with standard USGS procedures described by Rantz and others (1982). Measurements of instantaneous stream discharge were made throughout the study period at cross sections that had the most even and steady distribution of streamflow in the vicinity of diversions and USGS and CODWR streamgages. An 8-percent error generally was assigned to the instantaneous discharge measurements because of antecedent flow conditions at the cross sections.

\section{Slug Tests}

Instantaneous change-of-head tests (Theis, 1935), which commonly are referred to as "slug tests," were done in 29 wells in the study area during August and September 2009 to determine hydraulic properties of the alluvial-outwash and basin-fill aquifers. Tests were conducted using procedures described in USGS Groundwater Procedure 17 (Cunningham and Schalk, 2011). Water levels during the tests were measured and recorded using a submersible pressure transducer (Onset Computer Corporation's HOBO ${ }^{\circledR}$ U20 water-level data logger). The unvented (absolute) pressure transducer, which can record temperature and pressure at 1-second intervals, was suspended in the well 10 to $15 \mathrm{ft}$ below the static water level. Solid slugs alternately were submerged and extracted from the water column to cause "instantaneous" changes in water levels in the well. The slugs were constructed of 1-inch (nominal) diameter PVC pipe of various lengths, filled with sand, and sealed on both ends. The temperature of the transducer was allowed to equilibrate to in-situ water temperature for 10 to 15 minutes before conducting the slug tests. Slug-test data were analyzed using commercial aquifer-test software (AQTESOLV ${ }^{\circledR}$ for Windows, version 4.5; Duffield, 2004-07).

\section{Groundwater-Level Networks and Measurements}

Selection of wells for inclusion in the groundwater-level monitoring network for this study used a hexagonal grid and a ranking system to select wells within the grid cells. The portion of the study area underlain by the alluvial-outwash and basin-fill deposits (fig. 3) was divided into a grid of equalarea hexagonal cells, with each cell encompassing an area of about 1,926 acres (about $3 \mathrm{mi}^{2}$ ). Olea (1984) determined that a hexagonal sampling network minimizes the standard error of prediction for a network of spatially correlated values, such as 


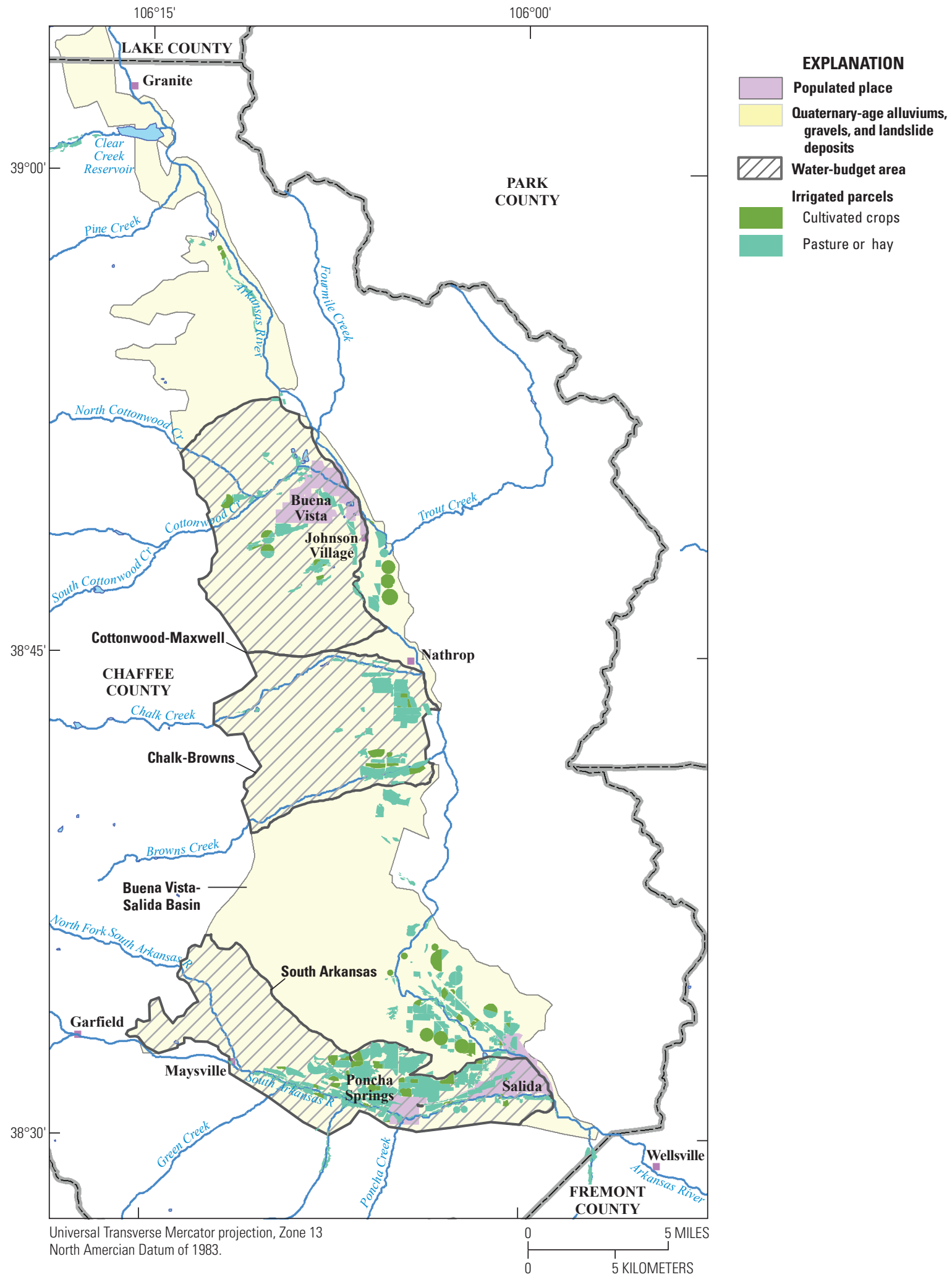

Figure 4. Irrigated parcels in selected water-budget areas of the Buena Vista-Salida Basin, Chaffee County, Colorado, 2011. 
groundwater levels, and that a random sampling pattern could require about 4.5 times as many sampling elements to achieve the same standard error.

A three-tiered ranking system was developed to select candidate wells within each cell for inclusion in the monitoring network. The first tier of the ranking system was based on well location. Approximate locations of existing wells within the study area were plotted based on location data obtained from the CODWR available at (https://data.colorado.gov/InformationSharing/DWR-Well-Application-Permit/wumm-7awb) using GIS. Potential candidate wells were ranked based on distance from the center of the respective hexagonal grid cell, with a higher (more desirable) rank given to those wells nearer the center of the cell. The second tier of the ranking system was based on availability and detail of well construction logs of the potential candidate wells (available at http://www.dwr.state.co.us/WellPermitSearch/default.aspx). Because detailed screened interval and well depth data for each candidate well were desired, a higher (more desirable) rank was given to those wells with detailed construction logs that defined at a minimum the screened interval and well depth. The third tier of the ranking system was based on availability and detail of lithology (drillers') logs for potential candidate wells (available at http://www.dwr.state.co.us/WellPermitSearch/default.aspx). Drillers' logs provide the primary documentation of subsurface materials in the study area and, though subjective, provide a qualitative basis for interpreting hydraulic and water-storage properties of the aquifers. Therefore, a higher (more desirable) rank was given to those wells with detailed drillers' logs. Based on the three-tiered ranking system, candidate wells within each cell were ranked and sorted.

Table 1. Coefficients used for estimating groundwater pumpage by water-use type in Cottonwood, North Cottonwood, Chalk, and Browns Creeks and South Arkansas River Basins.

\begin{tabular}{|c|c|c|c|}
\hline Water use & $\begin{array}{c}\text { Pumpage } \\
\text { coefficient } \\
\text { (acre-foot per } \\
\text { month per well) }\end{array}$ & $\begin{array}{l}\text { Number } \\
\text { of wells }\end{array}$ & $\begin{array}{c}\text { Return-flow } \\
\text { coefficient } \\
\text { (acre-foot per } \\
\text { month per well) }\end{array}$ \\
\hline \multicolumn{4}{|c|}{ Cottonwood Creek } \\
\hline Domestic $^{1}$ & 0.15 & 551 & 0.021 \\
\hline Household use only & 0.21 & 432 & 0.19 \\
\hline Commercial & 1.26 & 27 & 1.13 \\
\hline \multicolumn{4}{|c|}{ North Cottonwood Creek } \\
\hline Domestic $^{1}$ & 0.11 & 17 & 0.021 \\
\hline Commercial & 3.61 & 3 & 3.25 \\
\hline \multicolumn{4}{|c|}{ Chalk Creek } \\
\hline Domestic $^{1}$ & 0.12 & 240 & 0.021 \\
\hline Household use only & 0.11 & 127 & 0.10 \\
\hline Commercial & 0.2 & 17 & 0.18 \\
\hline \multicolumn{4}{|c|}{ Browns Creek } \\
\hline Domestic $^{1}$ & 0.10 & 41 & 0.021 \\
\hline Household use only & 0.11 & 55 & 0.10 \\
\hline Commercial & 0.013 & 1 & 0.01 \\
\hline \multicolumn{4}{|c|}{ South Arkansas River } \\
\hline Domestic $^{1}$ & 0.13 & 748 & 0.021 \\
\hline Household use only & 0.18 & 193 & 0.16 \\
\hline Commercial & 0.26 & 64 & 0.24 \\
\hline
\end{tabular}

${ }^{1}$ Includes wells supplying residences that are not occupied continuously.
Well owners were contacted and provided details of the study and were asked to participate. Wells were inspected to ensure that groundwater-level measurements were feasible and to determine geographic coordinates and establish measuring points. Geographic coordinates of wells were determined in the field with global positioning system equipment (Garmin GPS III Plus ${ }^{\mathrm{TM}}$ ). Land-surface altitudes were interpolated from a 10-meter (32.81 ft) digital elevation model (DEM) from the National Elevation Dataset (U.S. Geological Survey, 2008), based on the latitude and longitude coordinates of the well. The measuring point, defined as a fixed point on the well from which recurring water-level measurements were referenced, was defined during the initial well inspection. When a well met all selection criteria based on the three-tiered ranking system, owner participation, and field-inspection criteria, that well was selected as a project network well.

Electrical water-level-sensing tapes (either a $500-\mathrm{ft}$ Solinst Water Level Meter Model 102, or a 300-ft Slope Indicator Water Level Indicator) were used to measure groundwater levels periodically in the network wells, using procedures described in USGS Groundwater Procedure 4 (Cunningham and Schalk, 2011). Care was taken to determine if a well was being pumped, to avoid measurement when groundwater levels were fluctuating. Wells selected for the project network are domestic or household use water-supply wells that are pumped intermittently; therefore, groundwater levels could have been affected by recent pumping before the groundwater-level measurement.

\section{Data Analysis}

Simple spreadsheet analyses were used to compute gain/ loss from synoptic measurements and to compute water budgets of selected tributary basins in the study area. Database queries were developed to compute groundwater level altitudes and changes in groundwater levels between measurement periods. Maps showing generalized altitude of groundwater-level surfaces and changes in groundwater levels were prepared using GIS software, ArcGIS ${ }^{\circledR}$ and $\operatorname{ArcMap}^{\mathrm{TM}}$ (Environmental Systems Research Institute, Inc., variously dated).

\section{Water Budget}

The hydrologic cycle (fig. 5) describes the continuous movement of water on, above, and below the surface of the Earth. A water budget is a quantification of the components in that cycle for an area and time and simply states that change in water stored in an area is balanced by the rate at which water flows into and out of the area. The following is the basic water-budget equation:

$$
\text { Change in Storage }=\text { Inflow }- \text { Outflow }
$$

Although the basic water-budget equation (eq. 2) is simple, its implementation often is complicated because inflow and outflow may include several components, some of which are difficult to measure. Water-budget equations can be written in 
Table 2. Climate, stream-gaging and augmentation stations, diversion structures, and infiltration gallery in the Buena Vista-Salida Basin, 2011.

[COCC, Colorado Climate Center; CODWR, Colorado Division of Water Resources; COAgMet, Colorado Agricultural Meteorological Network; UAWCD, Upper Arkansas Water Conservancy District; USGS, U.S. Geological Survey; NAD83, North American Datum of 1983]

\begin{tabular}{|c|c|c|c|c|c|}
\hline $\begin{array}{c}\text { Station or structure } \\
\text { identification number } \\
\text { or abbreviation } \\
\end{array}$ & Station name & Site type & Agency & $\begin{array}{c}\text { Latitude NAD83 } \\
\text { (decimal } \\
\text { degrees) }\end{array}$ & $\begin{array}{c}\text { Longitude NAD83 } \\
\text { (decimal } \\
\text { degrees) }\end{array}$ \\
\hline \multicolumn{6}{|c|}{ Climate stations } \\
\hline BNV01 & Buena Vista & COAgMet & COCC & 38.8315 & -106.129 \\
\hline SLD01 & Salida & COAgMet & $\mathrm{COCC}$ & 38.5715 & -106.043 \\
\hline \multicolumn{6}{|c|}{ Stream-gaging stations } \\
\hline ARKGRNCO & Arkansas River at Granite & continuous & CODWR & 39.042778 & -106.265278 \\
\hline CCBCCRCO & Clear Creek below Clear Creek Reservoir & continuous & CODWR & 39.022222 & -106.235278 \\
\hline COCRHSCO & Cottonwood Creek below Hot Springs & continuous & UAWCD & 38.812486 & -106.222159 \\
\hline 385156106142801 & North Cottonwood Creek at Silver Creek Trailhead & seasonal & USGS & 38.865583 & -106.241194 \\
\hline 384952106104401 & North Cottonwood Creek above CR 361 & seasonal & USGS & 38.831361 & -106.178972 \\
\hline 384952106103800 & Cottonwood Creek below road CR 361 near Buena Vista, Colorado & seasonal & USGS & 38.830833 & -106.177778 \\
\hline COCRBVCO & Cottonwood Creek near Buena Vista & continuous & CODWR & 38.834444 & -106.122222 \\
\hline 384407106090901 & Chalk Creek above Chalk Creek Fish Hatchery ${ }^{1}$ headgates near Nathrop, Colorado & seasonal & USGS & 38.735333 & -106.152667 \\
\hline 384458106073901 & Chalk Creek below Chalk Creek Fish Hatchery ${ }^{1}$ near Nathrop, Colorado & seasonal & USGS & 38.749306 & -106.127389 \\
\hline CHCRNACO & Chalk Creek at Nathrop & continuous & CODWR & 38.741667 & -106.0825 \\
\hline 384100106065701 & Browns Creek above CR 261D near Nathrop, Colorado & seasonal & USGS & 38.683472 & -106.115833 \\
\hline 384132106042701 & Browns Creek on Wilson Ranch near Nathrop, Colorado & seasonal & USGS & 38.692278 & -106.074194 \\
\hline 384148106034201 & Browns Creek at mouth near Nathrop, Colorado & seasonal & USGS & 38.692278 & -106.074194 \\
\hline SOARGRCO & South Arkansas River below Garfield & continuous & UAWCD & 38.549414 & -106.256854 \\
\hline 383200106102501 & South Arkansas River near Maysville, Colorado & seasonal & USGS & 38.533306 & -106.173722 \\
\hline NFSOAKCO & North Fork South Arkansas River & continuous & UAWCD & 38.555874 & -106.19642 \\
\hline PNCKPSCO & Poncha Creek at Poncha Springs & continuous & UAWCD & 38.484859 & -106.085298 \\
\hline SOAKTECO & South Arkansas below Tenassee ditch ${ }^{2}$ & continuous & CODWR & 38.522274 & -106.011704 \\
\hline SOARSACO & South Arkansas River near Salida & continuous & CODWR & 38.521389 & -105.989167 \\
\hline ARKWELCO & Arkansas River near Wellsville & continuous & CODWR & 38.502778 & -106.939167 \\
\hline
\end{tabular}


Table 2. Climate, stream-gaging and augmentation stations, diversion structures, and infiltration gallery in the Buena Vista-Salida Basin, 2011.—Continued

[COCC, Colorado Climate Center; CODWR, Colorado Division of Water Resources; COAgMet, Colorado Agricultural Meteorological Network; UAWCD, Upper Arkansas Water Conservancy District; USGS, U.S. Geological Survey; NAD83, North American Datum of 1983]

\begin{tabular}{|c|c|c|c|c|c|}
\hline $\begin{array}{c}\text { Station or structure } \\
\text { identification number } \\
\text { or abbreviation }\end{array}$ & Station name & Site type & Agency & $\begin{array}{c}\text { Latitude NAD83 } \\
\text { (decimal } \\
\text { degrees) }\end{array}$ & $\begin{array}{c}\text { Longitude NAD83 } \\
\text { (decimal } \\
\text { degrees) }\end{array}$ \\
\hline \multicolumn{6}{|c|}{ Diversion Structures, Infiltration Gallery, and Augmentation Station } \\
\hline 650 & Cottonwood and Maxwell ditch & ditch & CODWR & 38.812167 & -106.214362 \\
\hline 1022 & Cottonwood and Maxwell augmentation station & augmentation station & CODWR & 38.812167 & -106.214362 \\
\hline 651 & Wolf and Neerland ditch & ditch & CODWR & 38.81221 & -106.209709 \\
\hline 670 & Gorrel Alternate ditch & ditch & CODWR & 38.830572 & -106.195566 \\
\hline 660 & Fehling ditch & ditch & CODWR & 38.830491 & -106.172397 \\
\hline 647 & Mahan ditch & ditch & CODWR & 38.834159 & -106.172379 \\
\hline 935 & Buena Vista Infiltration gallery & infiltration gallery & CODWR & 38.831398 & -106.171242 \\
\hline 648 & Cottonwood Irrigating 1 ditch & ditch & CODWR & 38.834159 & -106.172379 \\
\hline 653 & Bray and Mahon ditch & ditch & CODWR & 38.834159 & -106.172379 \\
\hline 644 & Leesmeagh ditch & ditch & CODWR & 38.837762 & -106.163132 \\
\hline 658 & Shamrock ditch & ditch & CODWR & 38.841421 & -106.163084 \\
\hline 645 & Thompson ditch & ditch & CODWR & 38.845039 & -106.153517 \\
\hline 652 & Flinchpaugh ditch & ditch & CODWR & 38.848637 & -106.14404 \\
\hline 646 & Prior Right ditch & ditch & CODWR & 38.834133 & -106.167783 \\
\hline 795 & Supply ditch & ditch & CODWR & 38.846868 & -106.13703 \\
\hline 719 & Trout Creek ditch & ditch & CODWR & 38.802694 & -106.081001 \\
\hline 2071 & Hatchery Headgate No. 1 & ditch & CODWR & 38.739501 & -106.153607 \\
\hline 684 & Willowdale ditch & ditch & CODWR & 38.73947 & -106.148997 \\
\hline 695 & Upper Mill ditch & ditch & CODWR & 38.746757 & -106.116321 \\
\hline 686 & Frantz ditch & ditch & CODWR & 38.748576 & -106.114004 \\
\hline 688 & Link and Irving ditch & ditch & CODWR & 38.74399 & -106.098721 \\
\hline 634 & Erhart and Bertschey ditch & ditch & CODWR & 38.684261 & -106.11022 \\
\hline 632 & Pioneer (Browns) ditch & ditch & CODWR & 38.687441 & -106.105661 \\
\hline 631 & Evans No. 2 ditch & ditch & CODWR & 38.682717 & -106.117146 \\
\hline 789 & Smith No. 2 (Browns) ditch & ditch & CODWR & 38.685708 & -106.098692 \\
\hline 629 & Smith No. 1 (Browns) ditch & ditch & CODWR & 38.68744 & -106.10566 \\
\hline 1138 & Gilliland No. 2 ditch & ditch & CODWR & 38.687253 & -106.087188 \\
\hline 628 & Gilliland No. 1 ditch & ditch & CODWR & 38.687253 & -106.087188 \\
\hline 825 & Gilliland No. 3 ditch & ditch & CODWR & 38.692173 & -106.070908 \\
\hline
\end{tabular}

${ }^{1}$ The official fish hatchery name as listed on the Colorado Parks and Wildlife website (http://cpw.state.co.us/learn/Pages/Hatcheries.aspx) is the "Chalk Cliffs Rearing Unit."

${ }^{2}$ The station name, as listed on the CODWR Web site (http://www.dwr.state.co.us/Surfacewater/data/stationdescription.aspx?ID=SOAKTECO\&MTYPE=DISCHRG), is "South Arkansas below Tennassee ditch"; however, the correct spelling of the diversion structure (ditch) as listed in the water rights decree is "Tenassee ditch." 


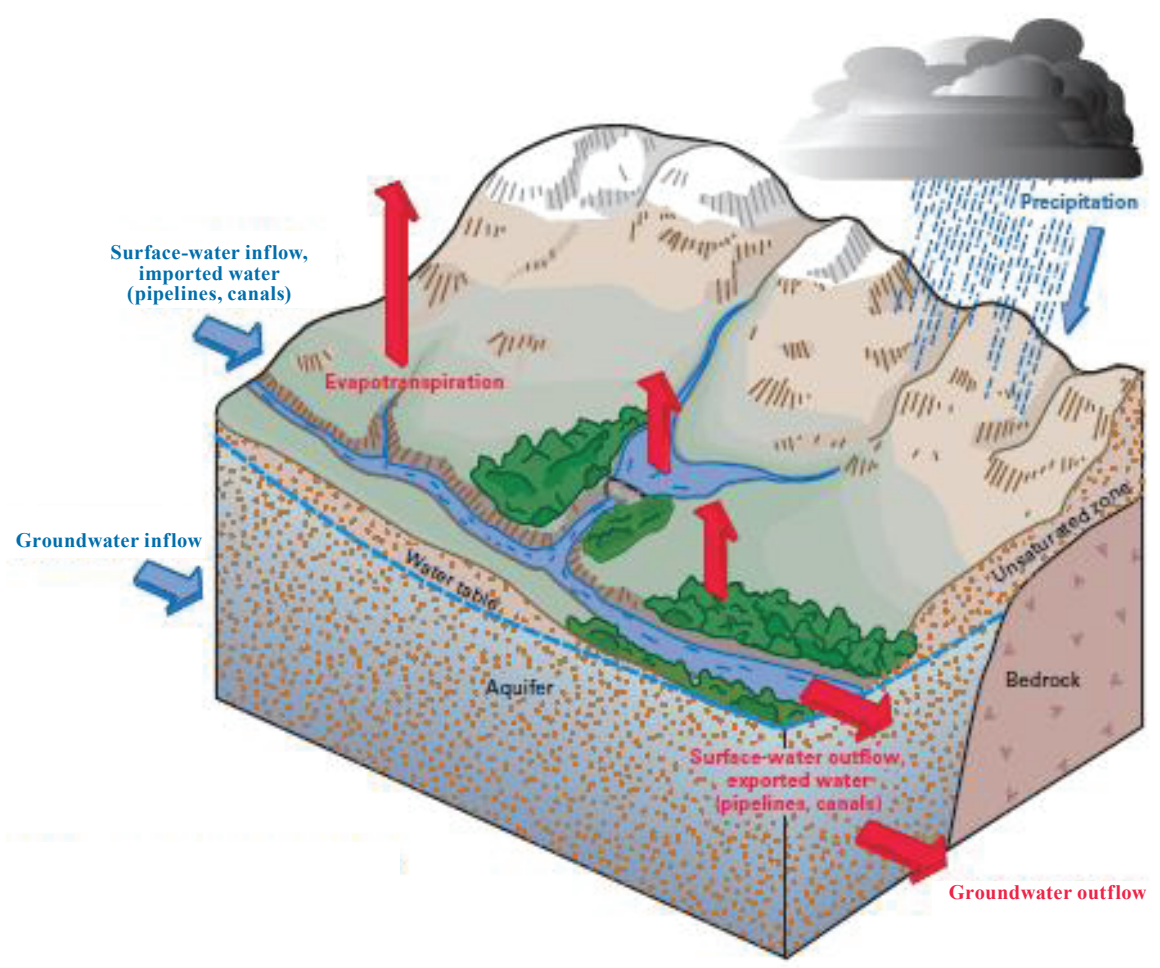

Figure 5. The hydrologic cycle for part of a watershed (Healy and others, 2007).

terms of volumes (for a fixed time interval), fluxes (volume per time, such as cubic meters per day or acre-feet per year), or flux densities (volume per unit area of land surface per time, such as millimeters per day) (Healy and others, 2007). In this report, water budgets are reported in terms of volume per time.

Components of the water budget of the Buena VistaSalida Basin include $Q_{u s} ; Q_{d s} ; Q_{s w d}$; irrigation requirement, as consumptive use (which includes precipitation) by irrigated crops and pasture $\left(C U_{i r}\right)$; groundwater pumpage $\left(Q_{\text {gwp }}\right)$; return flows to groundwater $\left(Q_{\text {gwr }}\right)$; and changes in groundwater storage $\left(\Delta S_{g w}\right)$. Other components of the water budget in irrigated areas that are not explicitly quantified include bank storage, return flows of diversions, conveyance losses from canals and ditches, and evapotranspiration from the water table. Generally, the alluvial deposits along stream channels in the Buena Vista-Salida Basin consist of sand, gravel, cobbles, and boulders, which are permeable, thus bank storage along streams drains rapidly back to the streams and is not a substantial component of the water budget for monthly or longer time periods. The change in groundwater storage for selected areas was computed by solving two components of the water budget separately. Equation 3 was used to calculate the net change (gain or loss) in streamflow $\left(\Delta Q_{s f}\right)$ within a stream segment (between gages) by month:

$$
\Delta Q_{s f}=Q_{d s}-Q_{u s}-Q_{s w d}-Q_{g w p}+Q_{g w r f}
$$

Surface return flows of diversions within the Buena Vista-Salida Basin, with few exceptions, are assumed to be minimal. Surface return flows of diversions for aquaculture (fish hatcheries) and at augmentation stations are exceptions and are accounted for in the budgets. Equation 4 was used to compute the groundwater recharge $\left(Q_{g w r}\right)$ :

$$
Q_{g w r}=Q_{s w d}-C U_{i r}-Q_{g w p}+Q_{g w r f}
$$

Though not explicitly calculated, conveyance losses from canal leakage are included in the calculation of $Q_{g w r}$. The net effect of not explicitly defining conveyance losses is that groundwater recharge is underestimated in nonirrigated parts of the basin that are crossed by canals and ditches and overestimated in irrigated areas, but it is assumed that net effect is small at a basin level of detail. Evapotranspiration directly from the water table likely occurs only in narrow corridors along streams, where the water table is near land surface, and is assumed to be minimal. The change in the saturated volume of the aquifer $(\Delta \mathrm{b})$, as estimated from groundwater-level measurements, is compared to the $Q_{g w r}$ to estimate specific yield $(S y)$ of the alluvial-outwash aquifer in each study basin, with the following equation:

$$
S y=Q_{g w r} / \Delta b
$$

\section{Potential for Underground Water Storage}

Areas in the Buena Vista-Salida Basin with potential for underground water storage were identified using GIS analysis of geologic, hydrologic, topographic, and soils data. An analytical equation was implemented in GIS to calculate stream-accretion response-time factors (saf) for locations within about $6.2 \mathrm{mi}(10,000$ meters [m]) of the Arkansas 
River and selected perennial tributary streams in that part of the Buena Vista-Salida Basin that is underlain by alluvial, glacial, and basin-fill deposits (fig. 2). Criteria used for selection of areas with potential for underground water storage were (1) the underlying unsaturated zone and uppermost aquifer consist of alluvium or glacial outwash (based on geology from Tweto [1979] and Green [1992]); (2) depth to groundwater was greater than about $20 \mathrm{ft}(6.1 \mathrm{~m})$ below land surface during part of the year (see Groundwater-Level Networks and Measurements section); (3) the slope of the land surface is less than 3 percent, which is about 15.6 feet per mile ( $\mathrm{ft} / \mathrm{mi}$ ) (82.37 meters per kilometer) (derived from a 10 -meter $[32.81 \mathrm{ft}$ ] digital elevation model [DEM] from the National Elevation Dataset [U.S. Geological Survey, 2008]); and (4) the soil is classified as sand, sandy loam, or loam (Soil Survey Staff, Natural Resources Conservation Service, U.S. Department of Agriculture, 2013; available from http://datagateway.nrcs.usda.gov/).

The saf is equivalent to the stream-depletion factor (SDF) of Jenkins (1968a, 1968b, 1968c). The saf is based on an analytical equation (commonly known as the Glover solution) that expresses the rate of streamflow depletion or accretion resulting from discharge from or recharge to the aquifer at a well (at a point) as a function of time (Glover and Balmer, 1954). Jenkins (1968c) noted that "Virtually all the literature that discusses the effects of pumping on streamflow fails to mention that the effects of recharge are identical, except for direction of flow." In this report, the Glover solution is defined to express the total rate of streamflow accretion resulting from recharge at a point, as a function of time. The volume streamflow accretion $\left(Q_{s a}\right)$ is equal to the product of the recharge rate, $Q_{r}$, and a mathematical function, referred to as the complementary error function, $\operatorname{erfc}(\mathrm{z})$ :

$$
Q_{s a}=Q_{r} \operatorname{erfc}(z)
$$

where the variable $z$ equals $\left[\left(d^{2} \mathrm{~S}\right) /(4 \mathrm{~T} t)\right]^{0.5}$, where $d$ is the shortest distance from the point of recharge to the stream; $S$ is the storage coefficient of the aquifer, which is equal to Sy for unconfined conditions; $T$ is the transmissivity of the aquifer; and $t$ is time. Jenkins (1968a, 1968b, 1968c) defined the stream depletion factor as $d^{2} \mathrm{~S} / \mathrm{T}$, which in this report is referred to as the saf. [Note that the complementary error function is a special S-shaped function that is used in the solutions of diffusion problems in heat, mass and momentum transfer, probability theory, the theory of errors, and various branches of mathematical physics. The error function can be used for solutions when the boundary conditions are in flux.] The saf has units of time, such as seconds or days, depending on the units of time used to express $T$. The saf is arbitrarily defined as the time $(t)$ at which the volume of streamflow accretion $\left(Q_{s a}\right)$ equals 28 percent of the volume of recharge $\left(Q_{r}\right)$ and occurs when $t \mathrm{~T} / d^{2} \mathrm{~S}=1.0$ (Jenkins, 1968a). Jenkins (1968c) summarized the assumptions on which the Glover solution is based, which have been modified herein to account for differences between discharge and recharge by a well:
1. The aquifer is homogeneous, isotropic, and extends to infinity away from the stream.

2. The aquifer is confined, and its transmissivity and saturated thickness do not change with time. When the solution also is applied to an aquifer with unconfined conditions (a water table), it is assumed that drawdown caused by mounding caused by injection or infiltration is small compared to the initial saturated thickness of the aquifer.

3. Water is added to storage instantaneously.

4. The stream that forms a boundary with the aquifer is straight, fully penetrates the aquifer, is infinite in length, remains flowing at all times, and is in perfect hydraulic connection with the aquifer (that is, the streambed and streambed sediments do not impede flow between the stream and aquifer).

5. The temperature of the stream and aquifer are the same and do not change with time. This assumption is necessary because variations in temperature affect the hydraulic conductivity of streambed and aquifer sediments.

6. Wells are open to the full saturated thickness of the aquifer.

7. The injection (accretion) rate is constant during periods of recharge.

Conditions required for application of the stream accretion or depletion factor approach often are not fully met, such as where aquifers are bounded laterally by low-permeability rocks or sediments (Barlow and Leake, 2012). Differences between field conditions and the method's assumptions are discussed later in the report, in the "Potential for Underground Storage in the Buena Vista-Salida Basin" section.

The area underlain by the alluvial-outwash and basinfill aquifers in the study area (fig. 2) was divided into 100-m square grid cells. Distances from the center of the grid cells to selected streams were calculated using GIS. The selected streams include the Arkansas and South Arkansas Rivers, Browns, Chalk, Cottonwood, and North Cottonwood Creeks, and the North Fork South Arkansas River. Multiple stream accretion factors were calculated for the points at the centers of the grid cells using the distances to adjacent streams and transmissivity and specific-yield values, which are described later in the "Potential for Underground Water Storage in the Buena Vista-Salida Basin" section of the report. Maps were prepared using GIS that show contours of equal saf values for each of the selected streams.

\section{Groundwater and Surface-Water Interaction}

Groundwater and surface water are interconnected in the Buena Vista-Salida Basin, where permeable unconsolidated alluvial, glacial outwash, and basin-fill deposits are in direct contact with streams (fig. 2). The climate in this intermountain basin is strongly affected by topography, with semiarid 
Groundwater and Surface-Water Interaction and Potential for Underground Water Storage, Buena Vista-Salida Basin, Colo.

conditions in the valley between the Sawatch and Mosquito Ranges. Groundwater recharge in the valley primarily occurs during the late spring and early summer from infiltration of snowmelt runoff in stream channels and from surface water diverted for irrigation. In wet years, infiltration of surfacewater diversions recharges the alluvial-outwash and basin-fill aquifers raising groundwater levels, but in dry years, when there is little snowmelt runoff and irrigation diversions are limited, groundwater levels decline substantially (Watts, 2005); however, even in dry years, groundwater continues to drain to the streams, sustaining base flow of the Arkansas River and its tributaries.

Estimates of groundwater contributions to base flow of the Arkansas River; synoptic (gain-loss) measurements of selected segments of Cottonwood, Chalk, and Browns Creeks; water budgets for each of the tributary streams, Cottonwood, Chalk, and Browns Creeks and the South Arkansas River Basins; groundwater-level hydrographs; and potentiometricsurface and groundwater-level change maps are used to demonstrate the dynamic nature of groundwater-surface-water interaction in the Buena Vista-Salida Basin.

\section{Estimated Base Flow of Arkansas River}

During 1999-2011, increases in annual streamflow of the Arkansas River in the Buena Vista-Salida Basin between the upstream gage at Granite and the downstream gage near Wellsville (fig. 3) generally were larger than the measured tributary inflow. Although flows of all tributaries to the Arkansas River in this segment were not measured, flows from ungaged tributaries are assumed to be relatively small. The net increase in streamflow of the Arkansas River adjusted for inflow of its gaged tributaries (Chalk, Clear, and Cottonwood Creeks, and the South Arkansas River) and reported diversions from the Arkansas River was assumed to result primarily from inflow of groundwater.

The increase in streamflow of the Arkansas River between Granite and Wellsville is, hereinafter, referred to as base flow and was estimated using mean monthly streamflow and reported diversions. Locations of streamgages used in the following discussion are shown in figure 3 and are listed in table 2. Monthly base flow $\left(Q_{\text {basefow }}\right)$ to the Arkansas River between Granite and Wellsville for 1999 through 2011 was estimated by subtracting gaged inflow of the Arkansas River at Granite $\left(Q_{\text {inffow }}\right)$ plus gaged inflow from Chalk, Clear, and Cottonwood Creeks, and the South Arkansas River $\left(Q_{\text {tributaries }}\right)$ minus reported diversions from the Arkansas $\operatorname{River}\left(Q_{\text {diversions }}\right)$ from the gaged outflow at Wellsville $\left(Q_{\text {outfow }}\right)$, using the following equation:

$$
Q_{\text {baseffow }}=Q_{\text {oufflow }}-\left[Q_{\text {inflow }}+Q_{\text {tributaries }}\right]-Q_{\text {diversions }}
$$

The annual sums of monthly diversions from the Arkansas River between Granite and Wellsville averaged about 22,000 acre-ft per year during 1999-2011 and ranged from about 7,000 acre-ft in 2002 to about 25,000 acre-ft in 1999, 2006 , and 2007 . The estimated monthly base flow values include all unmeasured inflows (groundwater, surface return flows of diversions, and inflow from ungaged tributaries) and errors in gaged streamflow and reported diversions.

Although the contribution to base flow from ungaged tributaries is unknown, it likely was relatively small. Diversions for irrigation capture much of the flow of the ungaged tributaries and infiltration of those diversions recharges the aquifers. For example, gaged outflow from Browns Creek to the Arkansas River during May through September 2011 was equivalent to only about 0.2 percent of the flow of the Arkansas River at Wellsville. Combined outflow of other ungaged tributaries in the Buena Vista-Salida Basin to the Arkansas River is estimated to be less than about 1 percent of the annual flow at Wellsville.

The annual volumes of estimated base flow (ungaged inflow) to the Arkansas River between Granite (ARKGRNCO) and Wellsville (ARKWELCO) during 1999-2011 averaged about 107,000 acre-ft and ranged from a low of about 68,000 acre-ft during the drought of 2002 to 143,000 acre-ft during 1999 (fig. 6). During 2010 and 2011, estimated annual base flow values were about 114,000 and 104,000 acre-ft, respectively. Estimated annual base flow during 1999-2011 ranged from about 16 to 33 percent of the gaged flow of the Arkansas River near Wellsville. In addition to year-to-year variations in base flow, the base flow estimates vary seasonally with minimum and maximum values generally occurring during February and June, respectively.

\section{Gain-Loss Measurements}

Gain-loss (synoptic) measurements of selected segments of Cottonwood, Chalk, and Browns Creeks were made August 9-11 and September 8-10, 2010, and April 27-29 and August 23-25, 2011. The synoptic measurements were used to identify gaining and losing segments of these perennial streams and to attempt to quantify those losses and gains and to identify temporal or seasonal patterns in gain-loss of the stream segments. Detailed diversion outflow data and tributary or seep inflow or return flow data used in the calculations of net gain and loss for the stream segments are shown in table 1-1. The average of the duplicate measurements was used for the net gain and loss calculations for the individual stream segments, and the net gain and loss calculations are summarized in table 3 . Based on the synoptic streamflow measurements, errors in 93 percent of the discharge measurements were 8 percent, thus the calculated net gain or loss of a segment is only reliable when it exceeds 8 percent of the largest of the duplicate measurements. Reported daily diversions from HydroBase rather than discharge measurements were used in calculations when landowner permission to access the measuring sites was not available. Because reported diversions in HydroBase are daily values, reported values used in 


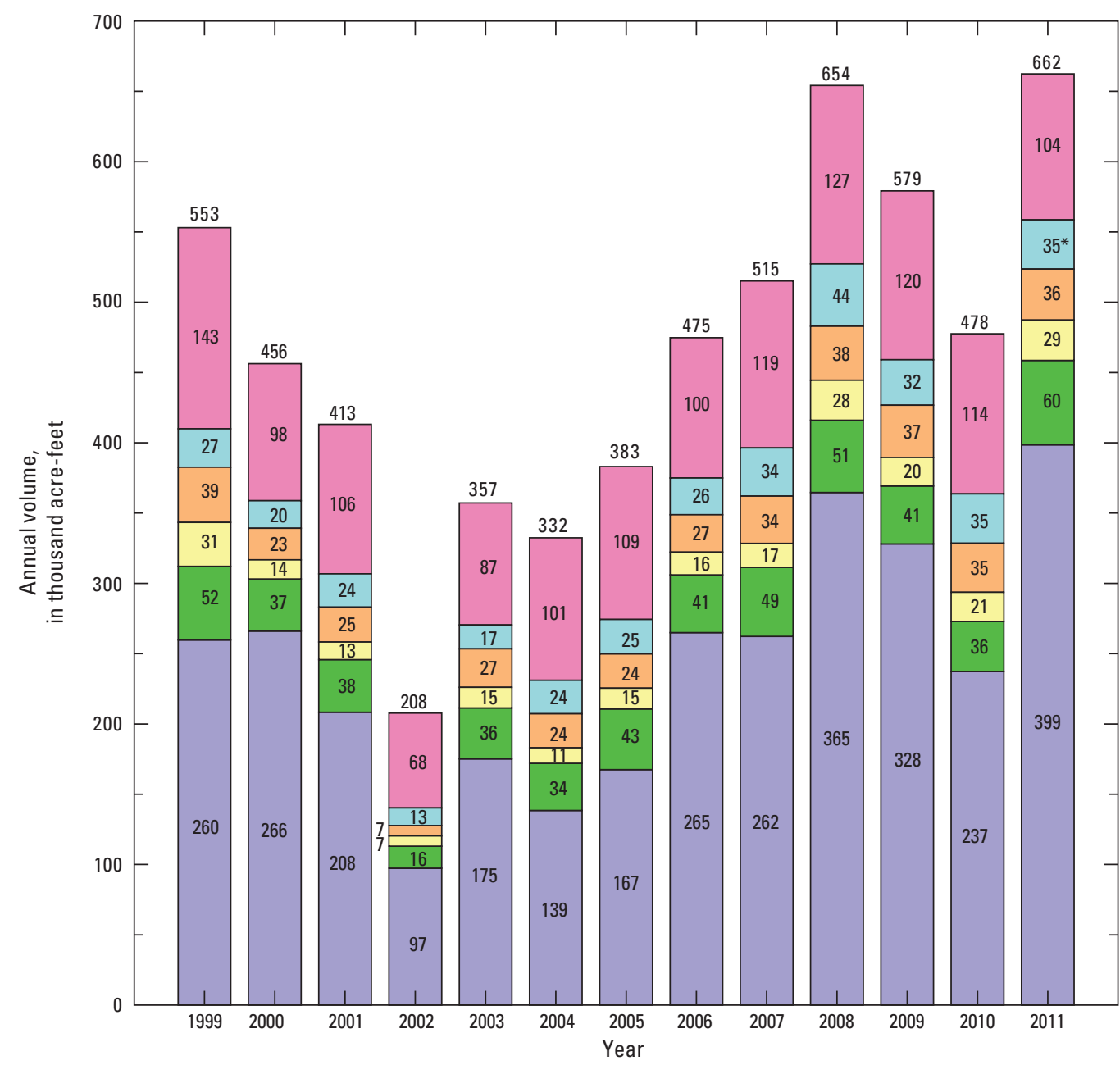

EXPLANATION

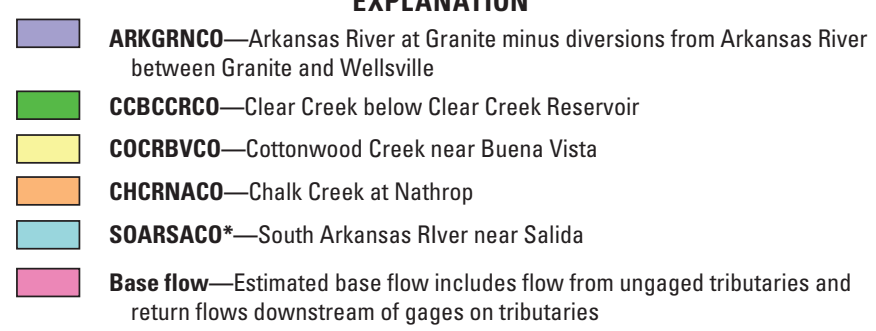

Figure 6. Gaged and base-flow components of streamflow of the Arkansas River near Wellsville, Colorado, 1999-2011. [Note: Number above bar is streamflow of Arkansas River near Wellsville (ARKWELCO). *Streamflow of South Arkansas River near Salida (SOARSACO) during July through December 2011 was estimated from streamflow of South Arkansas River below Tenassee Ditch (SOAKTECO).]

the gain-loss calculations have identical values and a relative percent difference of zero (table 1-1). The relative percent difference of measured values was calculated by dividing the difference of the two measurements by the mean of the two measurements [relative percent difference $=2 \times($ measurement 1 -measurement 2$) \div$ (measurement $1+$ measurement 2 )]. Errors in reported diversion values are unknown but comparison of discharge measurements through diversion structures with reported daily values for diversion rates through the same structures indicate that the error in reported values may be relatively large (greater than 20 percent) for some structures. Because the error in reported surface-water diversions cannot be quantified, the known discharge-measurement error of 8 percent was used as a quality control check in calculating gain or loss. In table 3, the calculated gains and losses were averaged for the duplicate measurements, and inconsistent averages are noted for values in which one set of measurements indicated a gain and the other a loss. 
Table 3. Summary of synoptic measurements of Cottonwood, Chalk, and Browns Creeks, and average groundwater gains and losses, August 9-11, 2010, September 8-10, 2010, April 27-29, 2011 and August 23-25, 2011.

[Values in red are losses from stream to groundwater, values in blue are gains to stream from groundwater, values in black are inconsistent with individual measurements indicating one gain and one loss; values in shaded cells are within the 8 percent error for discharge measurements; NA, not available]

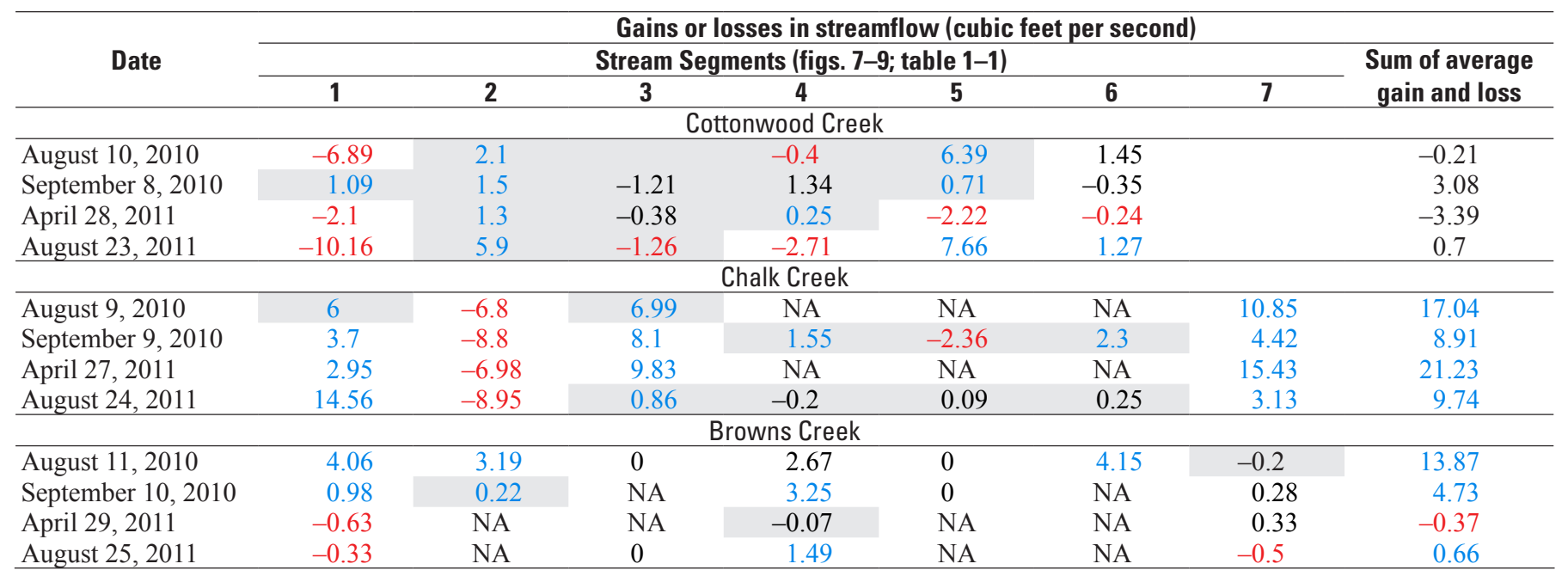

\section{Cottonwood Creek}

Averaged duplicate gain-loss measurements (table 3) of the six segments (fig. 7, table 1-1) on Cottonwood Creek suggest for each of the synoptics, segment 2 is a gaining stream; however, all of the measurements for this segment are in question. The calculated gains and losses for segment 2 as well as segment 3 and three of the four synoptics on segment 4 were within the 8 percent measurement error, making quantitative estimates for these segments questionable. Segment 1 (Cottonwood Creek at Cottonwood Hot Springs [COCRHSCO] to Cottonwood Creek below CR 361 [384952106103800]) of Cottonwood Creek for three of the four synoptics suggest that the stream is losing water to groundwater ranging from 2.10 to 10.16 cubic feet per second $\left(\mathrm{ft}^{3} / \mathrm{s}\right)($ table 3$)$.

Seasonal variations in stream characteristics may be suggested in Cottonwood Creek segments 5 and 6 where in the synoptic on April 28, 2011, the stream was losing water to groundwater, whereas in the synoptic on August 23, 2011, the segments were gaining water, most likely as groundwater discharge. Seasonal gains and losses in the lower stream segments 5 and 6 may suggest the losing segments are affected by preirrigation (irrigation prior to the crop growing season) as in the April synoptic but are gaining later in the season because irrigation water has infiltrated the shallow alluvial-outwash aquifer, resulting in groundwater discharges (streams gain water) in these lower stream segments. The synoptic on April 28, 2011, also has a negative sum of the average gains and losses for all the segments measured, suggesting groundwater gains, whereas the synoptics in August and September have positive sums suggesting groundwater discharge to Cottonwood Creek.

\section{Chalk Creek}

Average calculated gains and losses (table 3 ) for segment 1 (fig. 8, table 1-1) indicate Chalk Creek is gaining 2.95 to $14.56 \mathrm{ft}^{3} / \mathrm{s}$ in all four synoptics, potentially from groundwater, whereas segment 2 is losing 6.8 to $8.95 \mathrm{ft}^{3} / \mathrm{s}$ in all four synoptics. Chalk Creek in segment 3 is also calculated to be gaining, with groundwater potentially discharging 0.86 to $9.83 \mathrm{ft}^{3} / \mathrm{s}$ to the stream. Segments 1 through 3, from Chalk Creek above Chalk Creek Fish Hatchery headgates (384407106090901) to Chalk Creek below Chalk Creek Fish Hatchery (384458106073901), are located around the Chalk Cliffs Rearing Unit (fish hatchery) (fig. 8), with diversions in segments 1 and 3 , and the hatchery outflow pond (possibly contributing leakage to groundwater) also in segment 3 . For all four synoptics, segment 7 is a gaining stream, groundwater potentially discharging 3.13 to $15.43 \mathrm{ft}^{3} / \mathrm{s}$. Using reported headgate flow ratings as a substitute for measured April diversions (no landowner permission for access) in segment 7 may be the reason for the highest stream gains for the synoptics. The "NA" in segments 4, 5, and 6 for August 9, 2010, and April 27, 2011, are where there are no measurements because of the lack of landowner permission for access. Seasonal variability in the sum of all reach gain and loss is not evident in Chalk Creek, for all four synoptics, including the one conducted on April 27, 2011, suggesting that groundwater may be discharging to Chalk Creek before crop irrigation begins in middle to late April as well as later into the growing season in August and September and is likely affected by the fish hatchery. 


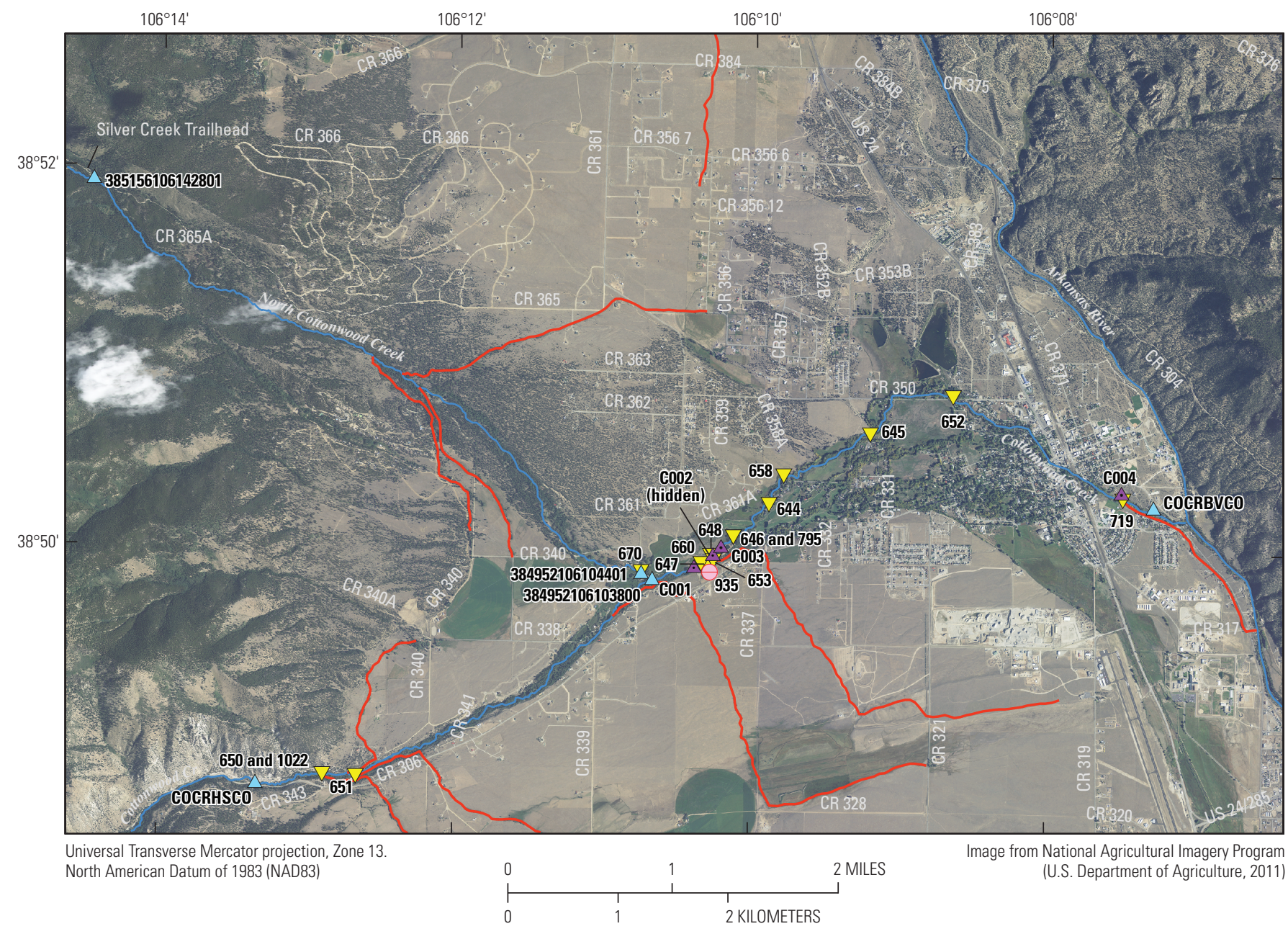

\author{
EXPLANATION \\ Irrigation canal or ditch
COCRHSCO $\triangle$ Streamgage-Shows location of streamgage.
Number or label is station identification number
or abbreviation (table 2) \\ C001 A Stream measurement-Shows location of discharge \\ measurement. Label is arbitrary number of \\ temporary site \\ $658 \quad$ Diversion structure-Shows location of diversion \\ structure or augmentation station. Number is \\ structure number \\ 935 Infiltration gallery - Shows location of infiltration \\ gallery. Label is structure number
}

Stream segments for water budgets and synoptic segment endpoints listed in table 1-1

Figure 7. Cottonwood Creek synoptic, diversion, and stream-gaging sites. 


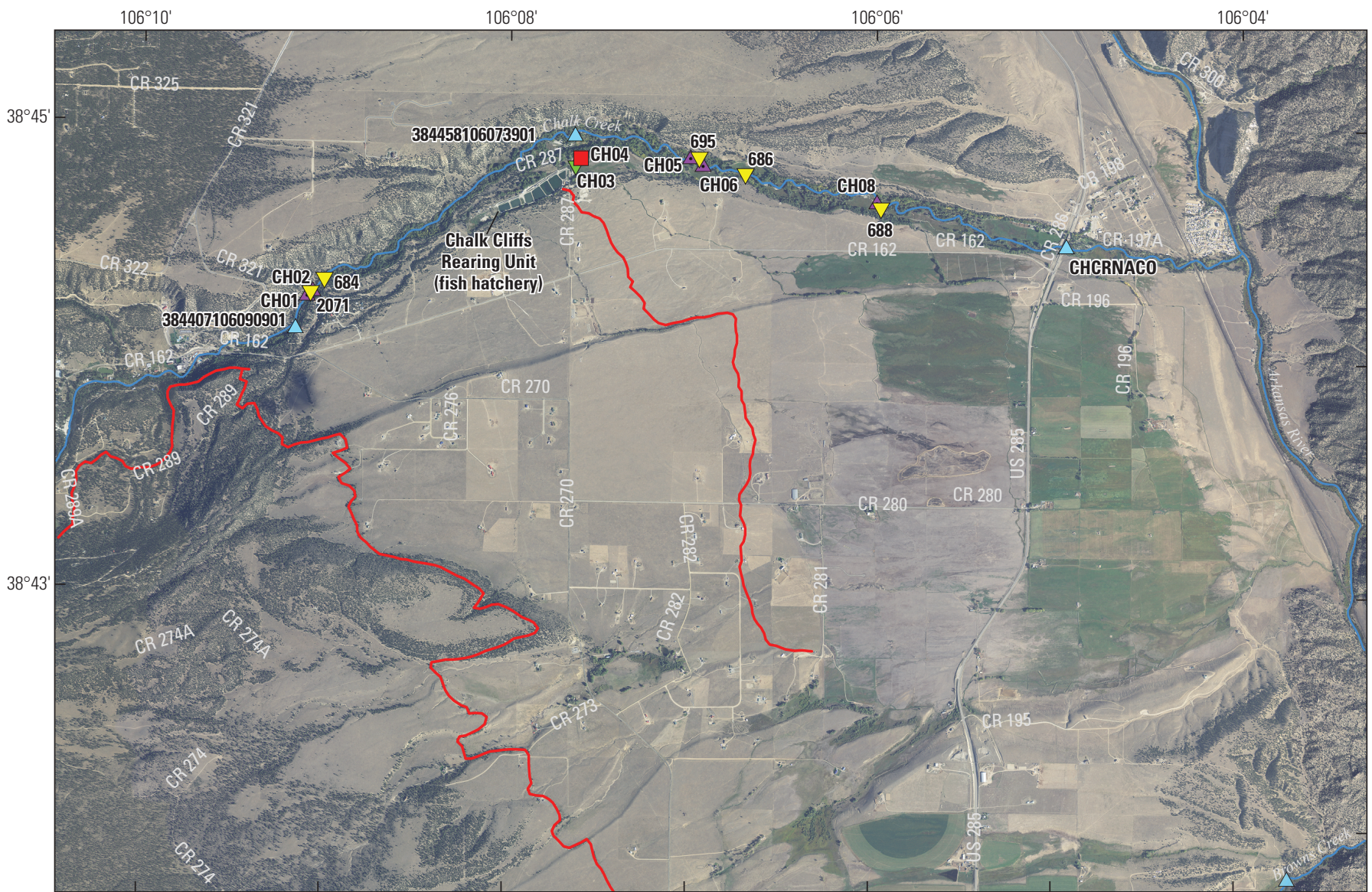

Universal Transverse Mercator projection, Zone 13. North American Datum of 1983 (NAD83)

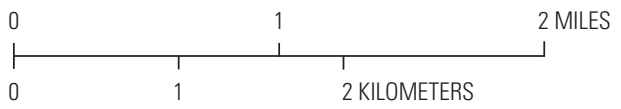

EXPLANATION

Irrigation canal or ditch

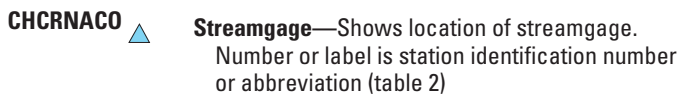

CH08 A Stream measurement-Shows location of discharge measurement. Label is arbitrary number of temporary site

$688 \quad$ Diversion structure-Shows location of diversion structure or augmentation station. Number is structure number

$\mathrm{CHO3}_{\nabla} \quad$ Flume- Shows location of measurement device. Label is arbitrary site name

CHO4 Return flow-Shows location of measured return flow. Label is arbitrary number

Stream segments for water budgets and synoptic segment endpoints listed in able 1-1

Figure 8. Chalk Creek synoptic, diversion, and stream-gaging sites. 


\section{Browns Creek}

For the Browns Creek synoptics, a number of segments were not measured because of lack of access ("NA" in table 3). Where measurements were made, segment 1 (Browns Creek above CR261D [38400106065701] to Browns Creek above Smith Ditch no.1 [BC01]) (fig. 9, table 1-1) in the 2010 synoptics was calculated to be a gaining stream, groundwater discharging 4.06 and $0.98 \mathrm{ft}^{3} / \mathrm{s}$, whereas in 2011, this same segment was losing -0.63 to $-0.33 \mathrm{ft}^{3} / \mathrm{s}$ (table 3 ). The year-toyear variability may be because diversion ditches in segment 1 were reported as dry in April 2011 and overall, less flow was measured (and consequently less water was diverted) in Browns Creek in August 2011 compared to August 2010 (table 3, table 1-1), resulting in the losing segment in 2011. Gains and losses calculated for segments 3 and 5 were zero for August 11, 2010; August 25, 2011 (segment 3); and August and September 2010 (segment 5), where the downstream gage was dry. No seasonal variation, as in Cottonwood Creek, is suggested in the individual segments; however, the sum of average gains and losses on Browns Creek for the synoptic on April 29, 2011, was calculated to a negative value. The negative value, as in Cottonwood Creek, may indicate an overall crop pre-irrigation stream loss and recharge of the alluvialoutwash aquifer, whereas the sums of the synoptics in August and September are positive, suggesting that irrigation water as groundwater may be discharging to Browns Creek later in the growing season.

\section{Findings of the Gain-Loss Measurement Analysis}

The four synoptics conducted on Cottonwood, Chalk, and Browns Creeks suggest quantifiable groundwater gains and losses in selected segments in all three perennial streams. Even though for each stream there were a number of caveats to the analysis including streamflow measurements that were within the measurement error, inconsistent calculated gain or loss, or measurements that were not available because of a lack of access to the synoptic sites. The synoptics on Cottonwood and Browns Creeks suggest a seasonal variability. In the April 2011 synoptic, the overall sum of the gains and losses for each stream was negative, indicating that the streams were losing water before crop irrigation to the alluvial-outwash aquifer. In August and September synoptics, the overall sum of the gains and losses was positive. The positive later-irrigation season values in Cottonwood and Browns Creeks suggest groundwater discharge, possibly as infiltrated irrigation water. The calculated overall sum of gains and losses on Chalk Creek does not indicate a seasonal variability as does Cottonwood and Browns Creeks, but indicates a gaining stream in April and August/September. Gains and losses in the measured upper segments of Chalk Creek likely are affected by the Chalk Cliffs Rearing Unit (fish hatchery).

\section{Water Budgets}

Monthly water budgets (eq. 3) were estimated for selected segments of five perennial streams (Cottonwood, North Cottonwood, Chalk, and Browns Creeks, and South Arkansas River) in the Buena Vista-Salida Basin (fig. 4) for calendar year 2011. The differences between gaged streamflow into and out of a stream segment and reported diversions from the stream within a segment were used to calculate net gains or losses of streamflow within the selected segments. Each stream segment had an upstream gage at which streamflow into the segment was gaged and a downstream gage at which streamflow out of the segment was gaged. Cottonwood, Chalk, and Browns Creeks and South Arkansas River were divided into upper and lower segments at intermediate gaging stations. Only two seasonal streamgages were operated on North Cottonwood Creek (fig. 3); therefore, it consists of a single segment for the water-budget analysis. Differences between reported diversions and estimated crop irrigation requirements were used to estimate groundwater recharge in the areas irrigated by water supplied from the diversions. In all of the study basins, under-irrigated areas (areas in which diversions may not meet crop water requirements) were difficult to identify and treat separately from the fully irrigated areas but were assumed to receive the full crop water requirement. Identification of under-irrigated areas would have required surveying growers multiple times during the growing season and was beyond the scope of the project. No diversions by wells within the study basins were reported in 2011 through the CODWR diversions records (available at http://cdss.state. co.us/onlineTools/Pages/StructuresDiversions.aspx) as being pumped for the purposes of irrigation, and were not included in the groundwater recharge calculation.

Cumulative precipitation at the Buena Vista and Salida CoAgMet stations during 2011 were 6.16 and 3.46 inches, respectively (Colorado State University, 2011). Crop irrigation requirements for the Cottonwood Creek and South Arkansas River water budgets were calculated by subtracting monthly precipitation values for the Buena Vista and Salida CoAgMet stations from the respective crop potential ET. Crop irrigation requirements for the Chalk Creek and Browns Creek water budgets were calculated by subtracting the averages of the monthly precipitation values from the Buena Vista and Salida CoAgMet stations from crop potential ET. Precipitation from summer storms (during the growing season) in the study area often is localized. Precipitation data from the two CoAgMet stations, which are located about $18 \mathrm{mi}$ apart (fig. 3 ), were tested to determine if there were statistical differences between median precipitation quantities from the two stations. Tests of the precipitation data from the two CoAgMet stations indicated that the data were not normally distributed and a non-parametric Wilcoxon rank-sum test (Helsel and Hirsch, 2002) was used to test the median precipitation quantity values. The null hypothesis for the test is that there 

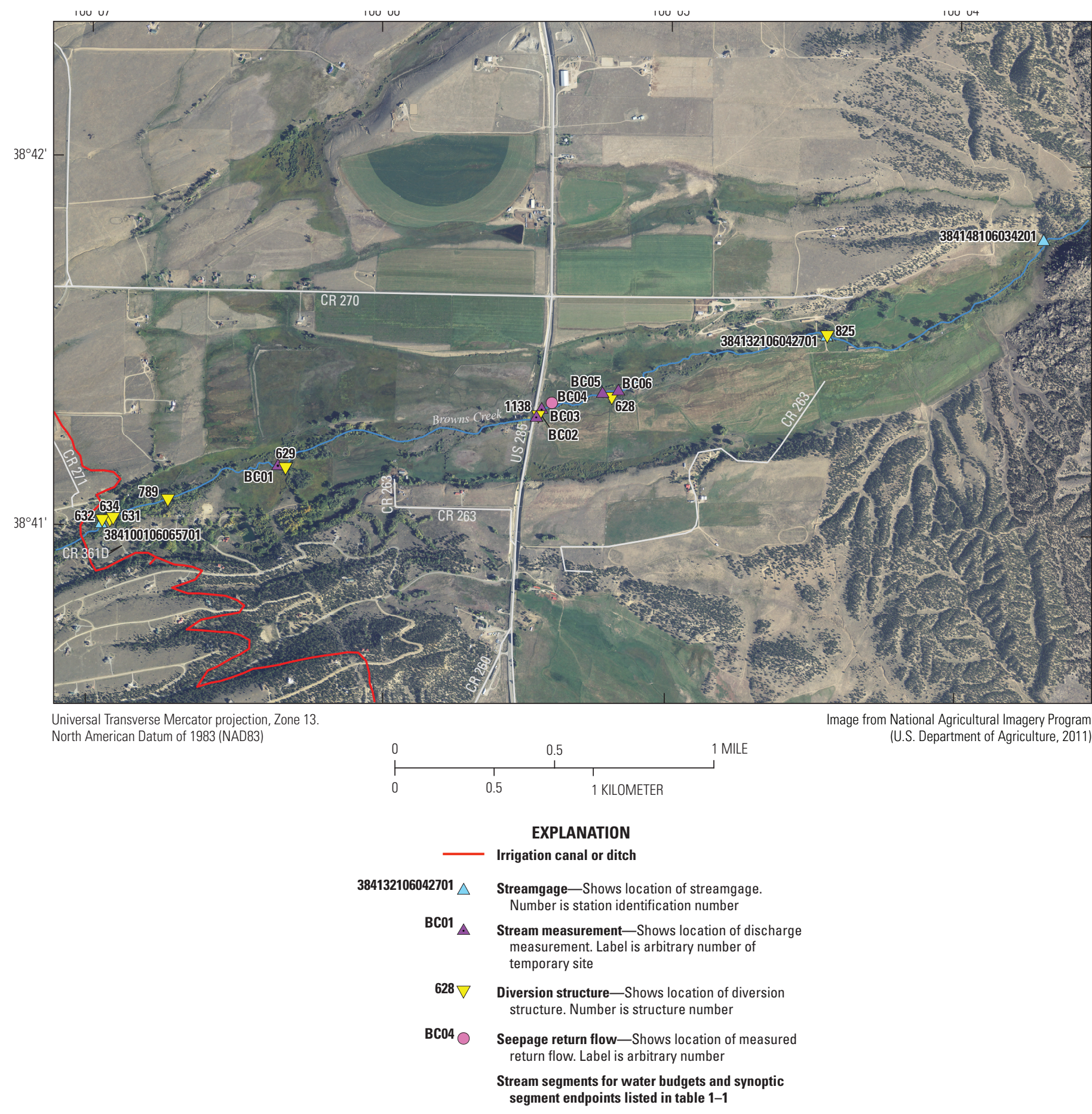

Figure 9. Browns Creek synoptic, diversion, and stream-gaging sites. 
is no statistical difference between the median quantity values from each precipitation gage and a significance level (alpha) of less than 0.05 was used in this report to accept or reject the null hypothesis. The probability value ( $p$-value) is the probability of rejecting the null hypothesis if it is true. A $p$-value of 0.026 (less than 0.05 ) was generated from the precipitation data, supporting the decision to reject the null hypothesis. There is a statistical difference in the median quantities from the two precipitation gages. Although data from these two stations are statistically different, the quantity data were averaged to calculate the crop irrigation requirement for Chalk and Browns Creek Basins. Ideally, numerous precipitation gages distributed throughout the Buena Vista-Salida Basin would provide better estimates of the spatial and temporal variability of precipitation.

Generally, withdrawals of groundwater by wells are not metered; however, because the use of water in Colorado is administered by the CODWR under the "Prior Appropriation System" (Colorado Division of Water Resources, 2013b), the use of groundwater may require augmentation of streamflow to offset stream depletions caused by well pumping. Surface water in the Arkansas River Basin is fully appropriated; therefore, augmentation plans are required for many wells. In addition to private augmentation plans, the UAWCD operates an augmentation program available to well owners within the Conservancy District. Under this program, the UAWCD meters the users' withdrawals and augments the surface-water flow to offset the usage by the subscribers. Users may include municipal, domestic, and commercial well owners. In 2010, augmented groundwater withdrawals in the study area for municipal, domestic, and commercial uses were an estimated 4,123 acre-ft. Groundwater withdrawals in 2011 were assumed similar to metered use for wells in 2010 participating in the UAWCD augmentation plan (Terry Scanga, Manager, Upper Arkansas Water Conservancy District, written commun., 2011). Groundwater withdrawals by wells not included in the UAWCD augmentation plan during 2011 were estimated to be about 2,626 acre-ft, assuming similar usage rates per well as wells under the UAWCD augmentation plan. Groundwater withdrawals by wells under the UAWCD augmentation program were estimated at about 1,085 acre-ft for domestic and household use, about 211 acre-ft for public-supply use, and about 201 acre-ft for commercial use. The public-supply water-use category included withdrawals by the town of Poncha Springs, Colo., mobile home parks, and homeowners associations. Diversions for public supply of Buena Vista, Colo., by an infiltration gallery in the alluvium beneath Cottonwood Creek were treated as surface-water diversions in the water budget for the Cottonwood Creek Basin (table 4).

Domestic groundwater withdrawals generally are for inhouse use and a large part is assumed to return to the water table as infiltration from individual sanitary disposal systems (ISDS), so the net effects of these withdrawals on water budgets and groundwater storage are relatively small. Infiltration from ISDS to the water table likely is relatively rapid because the soils and the alluvial-outwash and basin-fill deposits in the study are relatively permeable. Although the net effects of groundwater withdrawals on the water budgets and groundwater storage are relatively small, the estimates of withdrawals and return flows are included in the water budgets.

\section{Cottonwood Creek}

The surface-water budget for Cottonwood Creek (table 4) was subdivided into upper and lower segments at the seasonal gage above County Road 361 (CR 361; 384952106103800 ) (fig. 7). Streamflow $\left(\mathrm{Q}_{u s}\right)$ into the Cottonwood Creek Basin is gaged at Cottonwood Creek below Hot Springs (COCRHSCO) and outflow $\left(\mathrm{Q}_{d s}\right)$ from the basin at Cottonwood Creek near Buena Vista, Colo. (COCRBVCO). Seasonal gages also were operated on the North Cottonwood Creek (fig. 7) to determine gains and losses of North Cottonwood Creek and tributary inflow to the downstream segment of Cottonwood Creek. Reported diversions for irrigation $\left(\mathrm{Q}_{\text {swd }}\right)$ from Cottonwood Creek during January through October 2011 totaled 16,962 acre-ft. Water diverted by the Trout Creek ditch (diversion structure 719) was included in the calculations of net gain or loss between gages; however, this diversion is used for irrigation outside the Cottonwood Creek Basin on the eastern side of the Arkansas River and was not included in the calculations for groundwater recharge in the Cottonwood Creek Basin. Conveyance losses for this structure could be included in calculations for groundwater recharge, but were not available. Water returned to Cottonwood Creek as augmented flow through the Cottonwood and Maxwell augmentation station (tables 2 and 4) also was included in the water budget.

The net gain or loss $\left(\Delta \mathrm{Q}_{s w}\right)$ for the upper segment of Cottonwood Creek is negative, indicating that the stream is losing water to either the groundwater system or diversions, with the upper segment losing about 5,944 acre-ft and the lower segment gaining 579 acre-ft, (table 4) during the period April through October 2011. The calculated crop irrigation requirement $\left(\mathrm{CU}_{i r}\right)$ for 1,317 irrigated acres in the basin was calculated to be 2.45 acre-ft per acre for the months April through October 2011. The calculated April to September estimates of groundwater recharge for Cottonwood Creek Basin varied (table 4), with the greatest recharge in the months of June and July. Negative values for groundwater recharge indicate that crop irrigation requirements exceed the amount of reported diversions and not that groundwater was consumed to meet crop demand. Consequently and inclusively for the following discussions, negative values for monthly groundwater recharge are not included in annual totals of groundwater recharge. Groundwater recharge from infiltration of diversions from Cottonwood Creek, exclusive of the North Cottonwood Creek, and estimated groundwater withdrawals and returns totaled about 13,524 acre-ft during 2011. 
Table 4. Surface-water budgets and groundwater recharge for Cottonwood Creek Basin between Cottonwood Creek below Hot Springs and Cottonwood Creek near Buena

Vista, Colorado, and North Cottonwood Creek Basin between North Cottonwood Creek at Silver Creek Trailhead and North Cottonwood Creek above CR 361, 2011.

[All values rounded to nearest acre-foot; NA, not available; Negative values for net gain or loss in streamflow indicate a net loss between gages; Bold values are for months with partial records]

\begin{tabular}{|c|c|c|c|c|c|c|c|c|c|c|c|c|c|}
\hline $\begin{array}{c}\text { Surface-water } \\
\text { budget component }\end{array}$ & January & February & March & April & May & June & July & August & September & October & November & December & Totals \\
\hline \multicolumn{14}{|c|}{ Cottonwood Creek } \\
\hline Inflow at upstream gage ${ }^{1}$ & 1,541 & 1,053 & 1,053 & 1,097 & 3,222 & 19,090 & 11,615 & 3,337 & 2,099 & 1,786 & 1,708 & 1,304 & 48,905 \\
\hline Tributary inflow ${ }^{2}$ & NA & NA & NA & 6 & 197 & 3,748 & 2,924 & 673 & 308 & 45 & NA & NA & 7,901 \\
\hline Reported diversions ${ }^{3}$ & 0 & 0 & 0 & 0 & 295 & 2,588 & 2,555 & 1,625 & 1,139 & 878 & 0 & 0 & 9,080 \\
\hline Augmented flow ${ }^{4}$ & 0.22 & 0.23 & 0.28 & 0.24 & 0.43 & 0.51 & 0.42 & 0.43 & 0.41 & 0.33 & NA & 0.18 & 3.68 \\
\hline Flow at intermediate gage ${ }^{5}$ & NA & NA & NA & 436 & 2,327 & 14,799 & 11,094 & 3,004 & 1,845 & 216 & NA & NA & 33,721 \\
\hline Reported diversions $^{6}$ & 0 & 0 & 0 & 460 & 1,305 & 2,720 & 2,715 & 2,442 & 2,007 & 1,650 & 20 & 0 & 13,319 \\
\hline Diversions exported from basin ${ }^{7}$ & 0 & 0 & 0 & 278 & 495 & 977 & 1,012 & 1,032 & 849 & 774 & 20 & 0 & 5,437 \\
\hline Outflow at downstream gage ${ }^{8}$ & 1,577 & 1,208 & 1,130 & 232 & 470 & 10,047 & 8,190 & 821 & 127 & 462 & 1,735 & 1,682 & 27,681 \\
\hline Crop irrigation requirement & 0 & 0 & 0 & 463 & 606 & 803 & 531 & 384 & 190 & 250 & 0 & 0 & 3,227 \\
\hline $\begin{array}{l}\text { Net gain or loss between upstream } \\
\text { and intermediate gages }\end{array}$ & NA & NA & NA & NA & -797 & $-5,452$ & -890 & 619 & 577 & NA & NA & NA & $-5,944$ \\
\hline $\begin{array}{l}\text { Net gain or loss between intermediate } \\
\text { and downstream gages }\end{array}$ & NA & NA & NA & 692 & -552 & $-2,032$ & -189 & 259 & 289 & 2,112 & NA & NA & 579 \\
\hline $\begin{array}{l}\text { Total diversions for irrigation in } \\
\text { Cottonwood Creek Basin }\end{array}$ & 0 & 0 & 0 & 182 & 1,105 & 4,331 & 4,258 & 3,035 & 2,297 & 1,754 & 0 & 0 & 16,962 \\
\hline Estimated groundwater withdrawals & 217 & 217 & 217 & 217 & 217 & 217 & 217 & 217 & 217 & 217 & 217 & 217 & 2,604 \\
\hline Return flow, groundwater & 135 & 135 & 135 & 135 & 135 & 135 & 135 & 135 & 135 & 135 & 135 & 135 & 1,620 \\
\hline Groundwater recharge ${ }^{11}$ & -82 & -82 & -82 & -363 & 417 & 3,446 & 3,645 & 2,569 & 2,025 & 1,422 & -82 & -82 & 13,524 \\
\hline \multicolumn{14}{|c|}{ North Cottonwood Creek } \\
\hline Inflow at upstream gage ${ }^{9}$ & NA & NA & NA & 0 & 471 & 5,675 & 4,229 & 1,269 & 611 & 43 & NA & NA & 12,298 \\
\hline Reported diversions $^{10}$ & 0 & 0 & 0 & 0 & 237 & 1,084 & 1,335 & 993 & 538 & 265 & 10 & 0 & 4,462 \\
\hline Outflow at downstream gage ${ }^{2}$ & NA & NA & NA & 6 & 197 & 3,748 & 2,924 & 673 & 308 & 45 & NA & NA & 7,901 \\
\hline Crop irrigation requirement & 0 & 0 & 0 & 59 & 77 & 103 & 68 & 49 & 24 & 32 & 0 & 0 & 412 \\
\hline $\begin{array}{l}\text { Net gain or loss between upstream } \\
\text { and downstream gages }\end{array}$ & NA & NA & NA & NA & NA & -843 & 30 & 397 & 235 & NA & NA & NA & -181 \\
\hline Total diversions & 0 & 0 & 0 & 0 & 237 & 1,084 & 1,335 & 993 & 538 & 265 & 10 & 0 & 4,462 \\
\hline Estimated groundwater withdrawals & 63 & 63 & 63 & 63 & 63 & 63 & 63 & 63 & 63 & 63 & 63 & 63 & 756 \\
\hline Return flow, groundwater & 56 & 56 & 56 & 56 & 56 & 56 & 56 & 56 & 56 & 56 & 56 & 56 & 672 \\
\hline 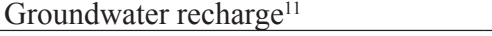 & -7 & -7 & -7 & -66 & 153 & 974 & 1,260 & 937 & 507 & 226 & 3 & -7 & 4,060 \\
\hline
\end{tabular}

${ }^{1}$ Upper Arkansas Water Conservancy District stream-gaging station Cottonwood Creek below Hot Springs, Colorado (COCRHSCO).

${ }^{2}$ U.S. Geological Survey seasonal streamgage on North Cottonwood Creek above CR 361, partial record April and October 2011.

${ }^{3}$ Sum of diversions from Cottonwood and Maxwell, Wolf and Neerland, and Arkansas Valley Irrigating ditches.

${ }^{4}$ Augmented flows from Cottonwood and Maxwell augmentation station.

${ }^{5}$ U.S. Geological Survey seasonal streamgage Cottonwood Creek below CR 361 (384952106103800), partial record April and October 2011.

${ }^{6}$ Sum of diversions from Fehling, Cottonwood Irrigating no. 2, Mahan, Cottonwood Irrigating no. 1, Leesmeagh, Shamrock, Thompson, Bray and Mahon, Flinchpaugh, Trout Creek, Prior Right, and Supply ditches.

${ }^{7}$ Diversions by Trout Creek ditch.

${ }^{8}$ Colorado Division of Water Resources stream-gaging station Cottonwood Creek near Buena Vista, Colorado (COCRBVCO).

${ }^{9}$ U.S. Geological Survey seasonal streamgage North Cottonwood Creek at Silver Creek Trailhead, partial record May and October 2011.

${ }^{10}$ Sum of diversions from Silver Creek-Ronk, McKenna, Bray no. 1, Richards, Marshall, and Gorrel Alternate ditches.

${ }^{11}$ Groundwater recharge is calculated as (diversions minus crop irrigation requirement) minus estimated groundwater withdrawals plus groundwater return flows. Negative values are not included in total. 
A separate surface-water budget was calculated for the tributary North Cottonwood Creek, as it is a large contribution to the Cottonwood Creek Basin groundwater and surfacewater budget. Streamflow into the North Cottonwood Creek was gaged at a seasonal gage at the Silver Creek trailhead (385156106142801). Outflow from the basin was gaged at a seasonal gage above CR 361 (384952106104401). The monthly gain or loss of the North Cottonwood Creek estimated for June 2011 is negative (table 4), indicating a net loss to groundwater, but positive during July through September, indicating a net gain from groundwater. Surface-water diversions during May through November from six structures totaled about 4,462 acre-ft. A crop irrigation requirement $\left(\mathrm{CU}_{i r}\right)$ of 2.45 acre-ft per acre was used to estimate crop consumptive use in the North Cottonwood Creek Basin. Groundwater recharge from infiltration of diversions from North Cottonwood Creek and estimated groundwater withdrawals and return flows totaled about 4,060 acre-ft. Combined with estimated groundwater recharge from infiltration of diversions from Cottonwood Creek of 13,524 acre-ft, estimated groundwater recharge for the entire Cottonwood Creek Basin in 2011 was about 17,584 acre-ft $(13,524+4,060=17,584)$.

\section{Chalk Creek}

The surface-water budget for Chalk Creek (table 5) is subdivided into upper and lower segments at the seasonal gage below the Chalk Creek fish hatchery (384458106073901; fig. 8). Streamflow into the Chalk Creek Basin was gaged seasonally (April through September 2011 at 384407106090901 ) upstream from the diversion for the Chalk Cliffs Rearing Unit (fish hatchery) (fig. 8). The upstream gage was operated seasonally, April through September 2011, thus the water budget for this basin is for that period. Streamflow out of the basin was gaged at Nathrop, Colo. (CHCRNACO). Reported diversions by irrigation ditches totaled 16,583 acre-ft during 2011 (table 5). Reported return flows by the Chalk Cliffs Rearing Unit (fish hatchery) totaled about 4,015 acre-ft during April through September 2011 with reported diversions for the hatchery equal to reported return flows (Chris Hertrich, Colorado Parks and Wildlife, Chalk Cliffs Rearing Unit,

Nathrop, Colo., oral commun., 2013). Evaporation from water surfaces in fish hatcheries would result in smaller outflows than inflows, and as the fish hatchery is located near Chalk Creek, seepage losses from the hatchery to groundwater would likely return to streams relatively rapidly. Inflow to, and consumptive use by, the hatchery are not reported. It was assumed that consumptive use by the hatchery was minimal and that inflows to the hatchery equaled reported outflows.

The calculated monthly gain or loss for the segments in Chalk Creek, from the upper gage above the fish hatchery to the seasonal gage below the fish hatchery return flow (the intermediate gage) were positive, indicating a gaining stream for this segment. The net gain or loss of streamflow for Chalk Creek from the gage below the hatchery to the gage at Nathrop, Colo., was negative (net losses), except during September, indicating a losing stream segment for most months (table 5). A crop irrigation requirement $\left(\mathrm{CU}_{i r}\right)$ of 2.64 acre-ft per acre for the estimated 1,329 acres irrigated April through September 2011 totaled 3,506 acre-ft. Estimated groundwater recharge during April through September varied (table 5), with the greatest recharge in June and July. Groundwater recharge from infiltration of diversions from Chalk Creek and estimated groundwater withdrawals and return flows (groundwater recharge) was about 12,957 acre-ft during 2011.

\section{Browns Creek}

The surface-water budget for Browns Creek (table 6) is subdivided into upper and lower segments at the seasonal gage on Browns Creek on Wilson Ranch (fig. 9). The upper study segment is between the gages at Browns Creek above CR261D (384100106065701) and Browns Creek on Wilson Ranch (384132106042701), and the lower segment is between the Browns Creek on Wilson Ranch and Browns Creek at the mouth (38384148106034201) (fig. 9). The water budget for Browns Creek was computed seasonally because all streamgages were operated seasonally, starting in April and ending in October 2011, with incomplete flow records for the months of April and October. Net gains were calculated for the upper and lower segments on Browns Creek, suggesting groundwater discharge in 2011 along the length of the study basin. Reported total diversions during 2011 were 3,105 acre-ft (table 6). A crop irrigation requirement of 2.64 acre-ft per acre for the estimated 937 acres irrigated by diversions from Browns Creek during April through September 2011 totaled 2,474 acre-ft. The water-budget components for Browns Creek are listed by month in table 6 .

Groundwater recharge in 2011 from infiltration of diversions from Browns Creek varied, with the greatest recharge occurring during July and August (table 6). Groundwater recharge as calculated from infiltration of diversions from Browns Creek and estimated groundwater withdrawals and return flows (groundwater recharge) was about 1,250 acre-ft during June through September 2011.

\section{South Arkansas}

The South Arkansas River was divided into upper and lower segments for the water budget. The upper segment is between the gage on the South Arkansas below Garfield (SOARGRCO) (fig. 3) and the seasonal gage near Maysville (383200106102501) (partial record May through September). The lower segment is between the seasonal gage near Maysville and the gage below the Tenassee ditch diversion (SOAKTECO). 
Table 5. Surface-water budget and groundwater recharge for Chalk Creek Basin between Chalk Creek above fish hatchery and Chalk Creek near Nathrop, Colorado, 2011.

[All values rounded to nearest acre-foot; NA, not available; Negative values for net gain or loss in streamflow indicate a net loss between gages; Bold values are for months with partial records]

\begin{tabular}{|c|c|c|c|c|c|c|c|c|c|c|c|c|c|}
\hline $\begin{array}{c}\text { Surface-water } \\
\text { budget component }\end{array}$ & January & February & March & April & May & June & July & August & September & October & November & December & Totals \\
\hline $\begin{array}{l}\text { Reported diversions into study area } \\
\text { upstream from gage }{ }^{1}\end{array}$ & 0 & 0 & 0 & 0 & 0 & 1,820 & 1,151 & 0 & 0 & 0 & 0 & 0 & 2,971 \\
\hline Inflow at upstream gage ${ }^{2}$ & NA & NA & NA & 496 & 3,949 & 18,240 & 10,788 & 3,852 & 2,640 & 252 & NA & NA & 40,217 \\
\hline Report diversions ${ }^{3}$ & 1,277 & 1,181 & 1,211 & 1,254 & 1,238 & 1,396 & 2,027 & 1,932 & 1,611 & 2,008 & 1,091 & 1,127 & 17,353 \\
\hline Return flows ${ }^{3}$ & 1,277 & 1,181 & 976 & 678 & 700 & 678 & 660 & 660 & 639 & 1,127 & 1,091 & 1,127 & 10,794 \\
\hline Net diversions ${ }^{3}$ & 0 & 0 & 235 & 576 & 538 & 719 & 1,366 & 1,272 & 972 & 881 & 0 & 0 & 6,559 \\
\hline Flow at intermediate gage $e^{4}$ & NA & NA & NA & 289 & 3,360 & 17,664 & 9,516 & 2,950 & 1,594 & 131 & NA & NA & 35,504 \\
\hline Report diversions $^{5}$ & 358 & 323 & 358 & 425 & 566 & 1,526 & 1,492 & 886 & 546 & 573 & 0 & 0 & 7,053 \\
\hline Outflow at downstream gage ${ }^{6}$ & 1,164 & 961 & 1,518 & 433 & 2,745 & 15,180 & 7,712 & 1,857 & 1,225 & 881 & 1,025 & 1,136 & 35,837 \\
\hline Crop irrigation requirement & 0 & 0 & 0 & 504 & 665 & 818 & 617 & 422 & 211 & 269 & 0 & 0 & 3,506 \\
\hline $\begin{array}{l}\text { Net gain or loss between upstream } \\
\text { and intermediate gages }\end{array}$ & NA & NA & NA & NA & 649 & 820 & 755 & 1,030 & 565 & NA & NA & NA & 3,819 \\
\hline $\begin{array}{l}\text { Net gain or loss between intermediate } \\
\text { and downstream gages }\end{array}$ & NA & NA & NA & NA & -49 & -958 & -312 & -207 & 177 & NA & NA & NA & $-1,349$ \\
\hline Total diversions (irrigation only) ${ }^{7}$ & 358 & 323 & 593 & 1,001 & 1,104 & 4,065 & 4,009 & 2,158 & 1,518 & 1,454 & 0 & 0 & 16,583 \\
\hline Estimated groundwater withdrawals & 36 & 36 & 36 & 36 & 36 & 36 & 36 & 36 & 36 & 36 & 36 & 36 & 432 \\
\hline Return flow, groundwater & 24 & 24 & 24 & 24 & 24 & 24 & 24 & 24 & 24 & 24 & 24 & 24 & 288 \\
\hline Groundwater recharge $^{8}$ & 346 & 311 & 581 & 485 & 427 & 3,235 & 3,380 & 1,724 & 1,295 & 1,173 & -12 & -12 & 12,957 \\
\hline
\end{tabular}

Groundwater recharge ${ }^{8}$

${ }^{2}$ Chalk Creek above fish hatchery diversion (384407106090901), seasonal record April and October 2011.

${ }^{3}$ Reported diversions Hatchery Headgate no. 1 and Willowdale ditch. Return flows at hatchery outflow pond reported as equal to diversions at Hatchery Headgate no. 1. Net diversions are equal to diversions minus return flows.

${ }^{4}$ Chalk Creek below fish hatchery, seasonal record April and October 2011.

${ }^{5}$ Sum of diversions from Upper Mill, Frantz, and Link and Irving ditches.

${ }^{6}$ Chalk Creek at Nathrop, Colorado (CHCRNACO).

${ }^{7}$ Does not include diversion for Chalk Cliffs Rearing Unit (fish hatchery).

${ }^{8} \mathrm{Groundwater}$ recharge is calculated as (diversions minus crop irrigation requirement) minus estimated groundwater withdrawals plus groundwater return flows. Negative values are not included in total. 
Table 6. Surface-water budget and groundwater recharge for Browns Creek Basin between Browns Creek above CR261D and Browns Creek at the mouth, 2011.

[All values rounded to nearest acre-foot; NA, not available; Negative values for net gain or loss in streamflow indicate a net loss between gages; Bold values are for months with partial records]

\begin{tabular}{|c|c|c|c|c|c|c|c|c|c|c|c|c|c|}
\hline Surface-water budget component & January & February & March & April & May & June & July & August & September & October & November & December & Totals \\
\hline Inflow at upstream gage ${ }^{1}$ & NA & NA & NA & 43 & 289 & 1,226 & 1,111 & 422 & 424 & 33 & NA & NA & 3,548 \\
\hline Reported diversions ${ }^{2}$ & 0 & 0 & 0 & 9 & 161 & 730 & 955 & 559 & 219 & 151 & 0 & 0 & 2,784 \\
\hline Flow at intermediate gage ${ }^{3}$ & NA & NA & NA & 39 & 75 & 269 & 295 & 109 & 236 & 20 & NA & NA & 1,043 \\
\hline Reported diversions ${ }^{4}$ & 0 & 0 & 0 & 2 & 31 & 65 & 60 & 10 & 131 & 22 & 0 & 0 & 321 \\
\hline Outflow at downstream gage ${ }^{5}$ & NA & NA & NA & 32 & 95 & 245 & 332 & 116 & 255 & 23 & NA & NA & 1,098 \\
\hline Crop irrigation requirement & 0 & 0 & 0 & 356 & 469 & 577 & 435 & 298 & 149 & 190 & 0 & 0 & 2,474 \\
\hline $\begin{array}{l}\text { Net gain or loss between upstream } \\
\text { and intermediate gages }\end{array}$ & NA & NA & NA & NA & -53 & -227 & 139 & 246 & 31 & NA & NA & NA & 136 \\
\hline $\begin{array}{l}\text { Net gain or loss between intermediate } \\
\text { and downstream gages }\end{array}$ & NA & NA & NA & NA & 51 & 41 & 97 & 17 & 150 & NA & NA & NA & 356 \\
\hline Total diversions & 0 & 0 & 0 & 11 & 192 & 795 & 1,015 & 569 & 350 & 173 & 0 & 0 & 3,105 \\
\hline Estimated groundwater withdrawals & 11 & 11 & 11 & 11 & 11 & 11 & 11 & 11 & 11 & 11 & 11 & 11 & 132 \\
\hline Return flow, groundwater & 6 & 6 & 6 & 6 & 6 & 6 & 6 & 6 & 6 & 6 & 6 & 6 & 72 \\
\hline Groundwater recharge $^{6}$ & -5 & -5 & -5 & -350 & -282 & 213 & 575 & 266 & 196 & -22 & -5 & -5 & 1,250 \\
\hline
\end{tabular}

${ }^{1}$ U.S. Geological Survey seasonal streamgage, Browns Creek above CR 261D, partial record April and October 2011.

${ }^{2}$ Sum of diversions from Erhart and Bertschey, Evans, Evans no. 2, Gilliland no. 1 and no. 2, Pioneer, and Smith no. 1 and no. 2 ditches.

${ }^{3}$ U.S. Geological Survey seasonal streamgage, Browns Creek at Wilson Ranch, partial record April and October 2011.

${ }^{4}$ Diversion from Gilliland no. 3 ditch.

${ }^{5}$ U.S. Geological Survey seasonal streamgage, Browns Creek at mouth, partial record April and October 2011.

${ }^{6}$ Groundwater recharge is calculated as (diversions minus crop irrigation requirement) minus estimated groundwater withdrawals plus groundwater return flows. Negative values are not included in total. 
Missing records from July through December 2011 precluded using the gage on the South Arkansas River near Salida (SOARSACO) for the water budget; therefore, streamflow at SOAKTECO was substituted. Tributary inflows from the North Fork South Arkansas River (NFSOAKCO) are included in the water budget for the upper segment. Locations of streamgages are shown in figure 3 . The water budget for the downstream segment, from the seasonal gage at Maysville to SOAKTECO, includes tributary inflow from Poncha Creek (PNCKPSCO). Reported diversions from the South Arkansas River totaled 29,724 acre-ft (table 7) in 2011, with 29,644 acre-ft of the total diversions from the downstream segment. Diversions by the D\&C pipeline ditch are not included in the reported diversions, because it is diverted (and returned) for a hydroelectric facility, a non-consumptive use. Also not included explicitly in this water budget is inflow from the three ungaged tributaries to the South Arkansas River: Green Gulch, an unnamed tributary, and Little Cochetopa Creek (fig. 3). No streamflow data were available for any of these three tributaries; however, flow from these streams is included in data from the main-stem South Arkansas River gages. Crop irrigation requirements $\left(\mathrm{CU}_{i r}\right)$ of 2.83 acre-ft per acre for 5,028 irrigated acres in the South Arkansas River Basin totaled 14,231 acre-ft during April through October 2011. Each component of the South Arkansas River water budget and calculated net gain or loss by segment and groundwater recharge are listed in table 7. The net gain or loss for the upper and lower segments were calculated for May through September, as the gage near Maysville was operated seasonally.

The calculated monthly net gain or loss for the upper segment in the South Arkansas River from the gage below Garfield to the seasonal gage near Maysville outfall was positive (net gain) during June and July and negative (net losses) during August and September. Net gain or loss for the lower segment of the South Arkansas River from the seasonal gage near Maysville to the gage below the Tenassee Ditch was negative (net losses) during June and July and positive (net gains) during August and September, indicating that groundwater is recharged during peak runoff periods and subsequently drains back to the river during late summer (table 7). Groundwater recharge for the South Arkansas River Basin varied (table 7) with the greatest recharge, as in the Cottonwood and Chalk Creek Basins, occurring during June and July. Groundwater recharge in the South Arkansas Basin during 2011 totaled about 16,020 acre-ft.

\section{Findings of the Water Budget Analysis}

Monthly water budgets (eq. 3) were estimated for selected segments of five perennial streams (Cottonwood, North Cottonwood, Chalk, and Browns Creeks, and South Arkansas River) in the Buena Vista-Salida Basin (fig. 4) for calendar year 2011. Differences between reported diversions and estimated crop irrigation requirements were used to estimate groundwater recharge in the areas irrigated by water supplied from the diversions. In all basins (except for North Cottonwood), the surface-water budget was subdivided into an upper and lower segment, with usually a seasonal gage as the intermediate gage.

The net gain or loss calculated for the upper and lower segments of each of the basins indicates that, if negative, the stream is losing water to either the groundwater system or diversions, or, if positive, the stream is gaining, suggesting a groundwater discharge. The upper segment of Cottonwood Creek was calculated to be losing about 5,944 acre-ft, whereas the lower segment was gaining 579 acre-ft, during April through October 2011. The upper segments of Chalk Creek and the South Arkansas River were calculated to be gaining segments, with groundwater discharging 3,819 acre-ft and 170 acre-ft, respectively. Lower segments in Chalk Creek and South Arkansas River were calculated to be a net loss, with 1,349 acre-ft and 8,941 acre-ft, respectively. Net gains for the upper and lower segments were calculated in Browns Creek, suggesting groundwater discharge in 2011 along the length of the study basin. The amount of groundwater recharge in all the basins varied monthly; however, the greatest amount of recharge occurred during June and July for Cottonwood, North Cottonwood, and Chalk Creeks, and South Arkansas River. The greatest amount of recharge in 2011 in Browns Creek occurred in July and August.

\section{Groundwater Levels, Change in Saturated Thickness, and Estimated Specific Yield}

Groundwater levels in an aquifer fluctuate in response to a variety of environmental changes, including short-term variations in nearby pumping and stream stage, and longterm changes in recharge to and discharge from the aquifer. Seasonal changes in groundwater recharge and discharge conditions cause changes in groundwater storage, as indicated by patterns in groundwater levels. If the specific yield and change in saturated volume of an unconfined aquifer are known, then change in groundwater storage can be estimated; conversely, when changes in groundwater storage and saturated volume are known, the specific yield can be estimated. Specific yield (Sy) is the ratio of the volume of water that will drain by gravity from a volume of saturated porous material to the total volume of porous material (Lohman and others, 1972). Specific yield often is difficult to determine by aquifer testing and alternatively specific yield is estimated using water-balance methods.

\section{Groundwater Levels}

Groundwater levels were measured in three monitoring networks (fig. 10) in the Buena Vista-Salida Basin during 2009-11. The three networks consist of a 17-well network that was installed and monitored by the CSUDCEE, a 50-well (project) network measured during this study, and a long-term monitoring network measured by the USGS in cooperation 
Table 7. Surface-water budget and groundwater recharge for South Arkansas River Basin between South Arkansas below Garfield and South Arkansas below Tenassee ditch near Salida, Colorado, 2011.

[All values rounded to nearest acre-foot; NA, not available; Negative values for net gain or loss in streamflow indicate a net loss between gages; Bold values are for months with partial records.]

\begin{tabular}{|c|c|c|c|c|c|c|c|c|c|c|c|c|c|}
\hline Surface-water budget component & January & February & March & April & May & June & July & August & September & October & November & December & Totals \\
\hline Inflow at upstream gage ${ }^{1}$ & 1,011 & 377 & 446 & 556 & 1,886 & 9,207 & 4,343 & 1,690 & 1,133 & 819 & 725 & 1,746 & 23,939 \\
\hline Tributary inflow ${ }^{2}$ & 254 & 300 & 358 & 362 & 1,106 & 4,938 & 2,416 & 910 & 621 & 539 & 602 & 513 & 12,919 \\
\hline Report diversions $^{3}$ & 0 & 0 & 0 & 0 & 0 & 46 & 34 & 0 & 0 & 0 & 0 & 0 & 80 \\
\hline Flow at intermediate gage ${ }^{4}$ & NA & NA & NA & NA & 2,560 & 14,151 & 7,233 & 2,307 & 1,657 & 127 & NA & NA & 28,035 \\
\hline Tributary inflow ${ }^{5}$ & 1,499 & 191 & 193 & 648 & 2,214 & 4,445 & 1,226 & 500 & 408 & 448 & 590 & 2,327 & 14,690 \\
\hline Report diversions $^{6}$ & 146 & 65 & 78 & 741 & 3,319 & 6,328 & 8,222 & 4,463 & 3,258 & 3,024 & 0 & 0 & 29,644 \\
\hline Outflow at downstream gage ${ }^{7}$ & 193 & 171 & 187 & 147 & 171 & 222 & 185 & 152 & 157 & 177 & 189 & 193 & 2,143 \\
\hline Crop irrigation requirement & 0 & 0 & 0 & 2,051 & 2,724 & 3,123 & 2,641 & 1,732 & 874 & 1,086 & 0 & 0 & 14,231 \\
\hline $\begin{array}{l}\text { Net gain or loss between upstream } \\
\text { and intermediate gages }\end{array}$ & NA & NA & NA & NA & NA & 52 & 508 & -293 & -97 & NA & NA & NA & 170 \\
\hline $\begin{array}{l}\text { Net gain or loss between intermediate } \\
\text { and downstream gages }\end{array}$ & NA & NA & NA & NA & NA & $-12,047$ & -52 & 1,808 & 1,350 & NA & NA & NA & $-8,941$ \\
\hline Total diversions & 146 & 65 & 78 & 741 & 3,319 & 6,374 & 8,256 & 4,463 & 3,258 & 3,024 & 0 & 0 & 29,724 \\
\hline Estimated groundwater withdrawals & 166 & 166 & 166 & 166 & 166 & 166 & 166 & 166 & 166 & 166 & 166 & 166 & 1,992 \\
\hline Return flow, groundwater & 79 & 79 & 79 & 79 & 79 & 79 & 79 & 79 & 79 & 79 & 79 & 79 & 948 \\
\hline Groundwater recharge $^{8}$ & 59 & -22 & -9 & $-1,397$ & 508 & 3,164 & 5,528 & 2,644 & 2,297 & 1,851 & -87 & -87 & 16,020 \\
\hline
\end{tabular}

${ }^{1}$ Upper Arkansas Water Conservancy District gage South Arkansas River (SOARGRCO) below Garfield, Colorado.

${ }^{2}$ Upper Arkansas Water Conservancy District gage North Fork of the South Arkansas River (NFSOAKCO), Colorado.

${ }^{3}$ Diversion from Paine ditch.

${ }^{4}$ U.S. Geological Survey temporary gage South Arkansas River near Maysville, Colorado, partial record May and October 2011.

${ }^{5}$ Upper Arkansas Water Conservancy District gage Poncha Creek at Poncha Springs, Colorado (PNCKPSCO).

${ }^{6}$ Sum of diversions from Maysville, Houge no. 2, WD White, Posterado, Missouri Park, Mundlien no. 1, Noland, Pinon, Burnett, Peeples, White no. 3 , Newby and Bowring, Boots and Hinton, Lowland, McPherson and Burnett, Ouray, Poncha Springs acequia, Harrington, South Arkansas WW and Irrigation, McCoy-Hutchinson, Briscoe, Salida "Old Gallery," White no. 1, Salida Reservoir, White no. 2, and Tenassee ditches.

${ }^{7}$ Colorado Division of Water Resources gage South Arkansas River below Tenassee ditch (SOAKTECO), Colorado. The station name, as listed on the CODWR website is "South Arkansas River below Tennassee ditch"; however, the correct spelling of the diversion structure (ditch) as listed in the water rights decree is "Tenassee ditch."

${ }^{8}$ Groundwater recharge is calculated as (diversions minus crop irrigation requirement) minus estimated groundwater withdrawals plus groundwater return flows. Negative values are not included in total. 
with the UAWCD. Only data from the CSUDCEE and project groundwater-level monitoring networks are discussed in this report. The long-term network is most useful for understanding year-to-year and multi-year trends.

The CSUDCEE network includes 17 dedicated monitoring wells in which groundwater levels and water temperatures are measured and recorded hourly, using submersible pressure transducers. The project network consists of 50 privately owned wells that were measured periodically (4 to 5 times per year). Data from the project network are available from the National Water Information System (NWIS) at http://waterdata.usgs.gov/nwis. Construction information for wells in the CSUDCEE and project groundwater monitoring networks are listed in table 1-2 in the appendix.

Hydrographs showing groundwater levels and temperatures for the 17 CSUDCEE monitoring wells during 2010 and part of 2011 are shown in figures 1-1 thru 1-17 in the appendix. Variations in groundwater levels and water temperature in the CSUDCEE monitoring wells indicate that recharge to the alluvial-outwash aquifer in the Buena Vista-Salida Basin generally occurs from April through July when the aquifer is recharged by diversions for irrigation (figs. 1-1 through 1-17). Groundwater levels in monitoring wells located near irrigated areas (fig. 10), except wells C11 and C14, generally exhibited larger ranges of fluctuation than monitoring wells in nonirrigated areas (wells $\mathrm{C} 03, \mathrm{C} 15$, and $\mathrm{C} 16$ ). Well $\mathrm{C} 11$ is located in a groundwater discharge area upgradient of the confluence of Browns Creek with the Arkansas River, where the alluvialoutwash aquifer pinches out against a bedrock high of granitic rocks (Tweto, 1979; Green, 1992). Because the hydraulic conductivity of granite typically is much less than that of unconsolidated alluvial-outwash deposits (Freeze and Cherry, 1979), groundwater outflow from the Browns Creek Basin directly to the Arkansas River is restricted, and groundwater levels during January 2010 through June 2011 fluctuated less than $3 \mathrm{ft}$ (fig.1-11). Well C14 is located adjacent to an irrigated field but likely is not downgradient of the area recharged by irrigation. Infiltration of diversion conveyance losses and return flows from irrigated fields are the principal sources of recharge to the alluvial-outwash aquifer. Although infiltration from streams is assumed to recharge groundwater near the mountain front (Watts, 2005), most of the available monitoring wells were not located adjacent to streams or were in discharge areas and had little response to changes in stream stage. Seasonal changes in depth to groundwater in the CSU-DCEE monitoring network ranged from less than 1 to about $26 \mathrm{ft}$ during January 1, 2010 through June 30, 2011 (figs. 1-1 through 1-17). Groundwater levels in 14 of the 17 monitoring wells were at maximum levels (shallowest depth to water) during late June through mid-July.

Groundwater at monitoring well C01 likely is recharged by infiltration from the Arkansas River (fig. 10). Monitoring wells $\mathrm{C} 07$ and $\mathrm{C} 08$ (figs. $1-7$ and 1-8, respectively) maintained relatively high groundwater levels of about 20 and $10 \mathrm{ft}$ above previous lows, respectively, from June through November, indicating continued recharge from irrigated fields.
Monitoring well C03 (fig. 1-3) reached its maximum level in January and wells C14 and C15 reached maximum level in November (figs. 1-14 and 1-15, respectively). Groundwater levels in these wells $(\mathrm{C} 03, \mathrm{C} 14$, and $\mathrm{C} 15)$ likely respond to seasonal inflow from upgradient irrigated areas but showed little variation during the study, indicating that groundwater levels were not affected directly by infiltration of streamflow or irrigation.

Groundwater levels from the wells used in this study and CSUDCEE monitoring well networks (fig. 10 and table 1-1) were used to construct potentiometric-surface maps (groundwater-level altitude maps) for March and June 2011 (figs. 11A and $11 B$ ). Groundwater levels for the CSUDCEE monitoring wells that were used in preparing figures $11 A$ and $11 B$ were the last measurements recorded for the respective months. Because the project monitoring wells primarily are domestic wells, groundwater levels likely are affected by intermittent pumping and may not represent static levels in the aquifer. Groundwater levels in project monitoring wells were not used to prepare the potentiometric surface maps (figs. $11 A$ and $11 B$ ) when the groundwater levels for the well varied substantially between successive measurements, indicating that measurements may have been affected by recent pumping of the well. The potentiometric surfaces (figs. $11 A$ and $11 B$ ) are highest along the mountain front and slope toward the Arkansas River, the regional groundwater drain.

\section{Change in Saturated Thickness}

The estimated change in saturated thickness in the Buena Vista-Salida Basin during March through June 2011 (fig. 11C) was computed, using the GIS, as the difference between the March 2011 (fig. 11A) and June 2011 potentiometric surfaces (fig. $11 B$ ). Note that in some areas in which the potentiometric surfaces (figs. $11 \mathrm{~A}$ and $11 \mathrm{~B}$ ) were computed primarily from groundwater levels measured in domestic wells (that is, the project monitoring network), the computed change in potentiometric levels may reflect the effects of recent pumping of the measured well or of nearby wells. For example, the computed increases in saturated thickness (purple areas) along the mountain front north of Cottonwood Creek (fig. 11C) may be artifacts of groundwater levels that were affected by recent pumping. In addition to the effects of pumping on groundwater levels, the GIS methods used to generate the potentiometric surfaces from point measurements may show substantial differences in successive potentiometric surfaces, particularly when those surfaces are projected outside the area constrained by measurements. The average change between the March and June 2011 potentiometric surfaces was an increase of about $0.85 \mathrm{ft}$ (fig. 11C). Computed change in saturated volume of unconfined aquifers in the Buena Vista-Salida Basin during March through June 2011 was about 127,000 acre-ft. Multiplying the change in saturated volume by specific yield provides an estimate of the groundwater recharge that occurred during that period. Specific yield of sand and gravel deposits typically range from about 0.1 and 0.3 (American Society of 


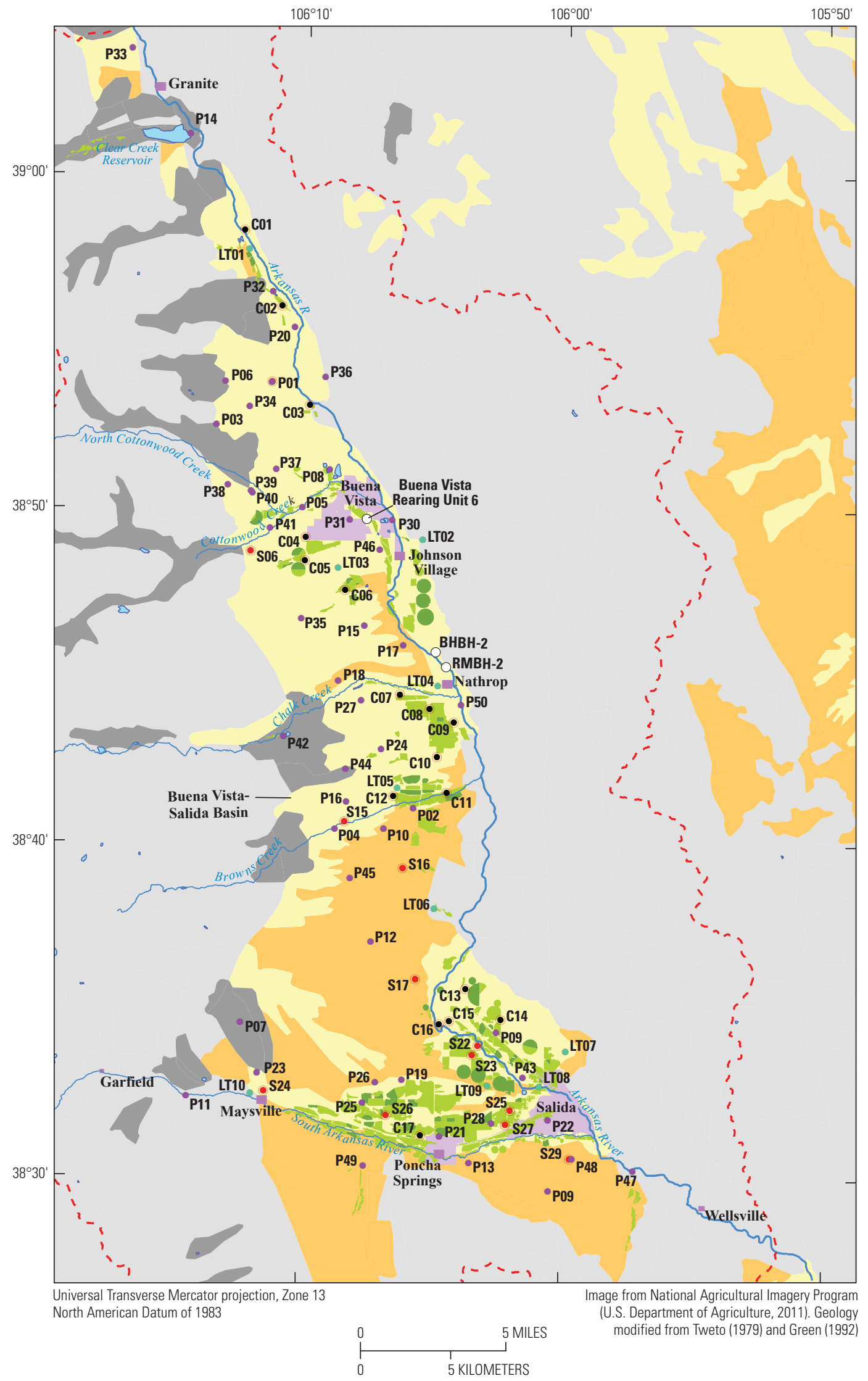

Figure 10. Groundwater monitoring wells and aquifer- and slug-test sites in the Buena Vista-Salida Basin. 


\section{EXPLANATION}

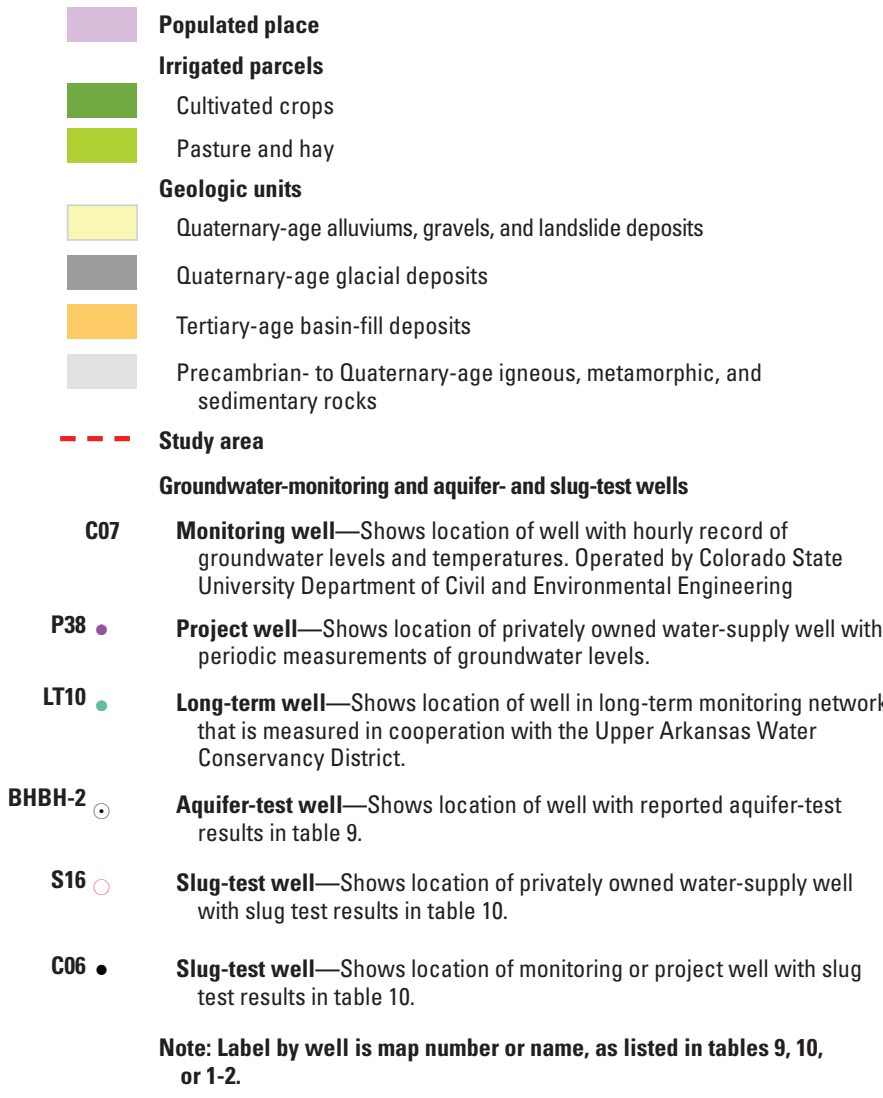

Civil Engineers, 1996), thus the change in groundwater storage in the Buena Vista-Salida Basin during March through June 2011 likely ranges from about 12,700 to 38,100 acre-ft in an area of about 154,600 acres. For comparison, the estimated groundwater recharge from the water budgets (tables 4-7) for March through June 2011 totaled about 13,603 acre-ft in an area of about 75,860 acres.

\section{Estimated Specific Yield}

A water-budget approach was used to estimate specific yield in the Buena Vista-Salida Basin. Estimated specific yield (table 8) was computed for three areas (fig. 11C) for which water budgets were available (tables 4-7) and groundwaterlevel change was reasonably constrained by data. Positive values of groundwater recharge for the months March, April, May, and June 2011 (tables 4-7) were summed and divided by the estimated change in saturated thickness of groundwater (fig. 11C) for the respective areas. The estimates were restricted to the period March through June 2011 because recharge, as indicated by depth to groundwater (figs. 1-1 through 1-17), generally was near seasonal maximums in March and seasonal minimums in late June or early July. Estimated specific yield values were $0.15,0.26$, and 0.12 (table 8 ), with an average value of 0.18 . These specific-yield values are within the range typical of sand and gravel deposits (American
Society of Civil Engineers, 1996). Actual specific-yield values likely are greater than the estimated values because some of the recharge from previous months likely had returned to streams before the end of June. Assuming an average specific yield of 0.18 and an average change of saturated thickness of about $0.85 \mathrm{ft}$, groundwater recharge in the area of the Buena Vista-Salida Basin underlain by the alluvial-outwash and basin-fill deposits during March through June 2011 was about 23,000 acre- $\mathrm{ft}(0.18 \times 0.85 \mathrm{ft} \times 154,600$ acres $)$.

\section{Potential for Underground Water Storage in the Buena Vista- Salida Basin}

The Colorado Water Conservation Board (2007) published a study, "SB06-193 Underground Water Storage Study," which identified and ranked areas within the Arkansas and Platte River Basins in which underground water storage might be feasible. The Colorado Water Conservation Board (2007, p. 10) stated,

\section{"Increasing population in Colorado and recent years of drought has placed an ever greater strain on Colorado's water resources. In addition to increasing water conservation and water reuse, there is a need to increase water storage. Due to increasing difficulties with building surface water storage reservoirs, there has been a growing interest in storing water underground in natural reservoirs associated with groundwater aquifers."}

The Buena Vista-Salida Basin, specifically the alluvialoutwash aquifer, was ranked as one of the top 10 areas for underground (water) storage projects in the Arkansas River Basin (Colorado Water Conservation Board, 2007). The quantity of water that can be recharged is constrained by the hydrologic and physical properties of the aquifer, including those of the unsaturated material above the water table. Because the alluvial-outwash aquifer in the study area is hydraulically connected with streams (Watts, 2005), it also is important to understand when and where water stored in the aquifer likely will discharge to receiving streams. Although economic, engineering, institutional, and legal factors must be considered in developing an artificial storage and recovery project, this analysis primarily is concerned with hydrologic factors limiting where the alluvial-outwash aquifer in the Buena Vista-Salida Basin has storage capacity and, if recharged, when water likely will discharge to streams. The relatively large seasonal fluctuations of groundwater levels near irrigated areas in the Buena Vista-Salida Basin (fig. 10 and figs. 1-1 through 1-17) indicate that increased groundwater storage resulting from infiltration of surface-water diversions has dissipated by the following spring. 


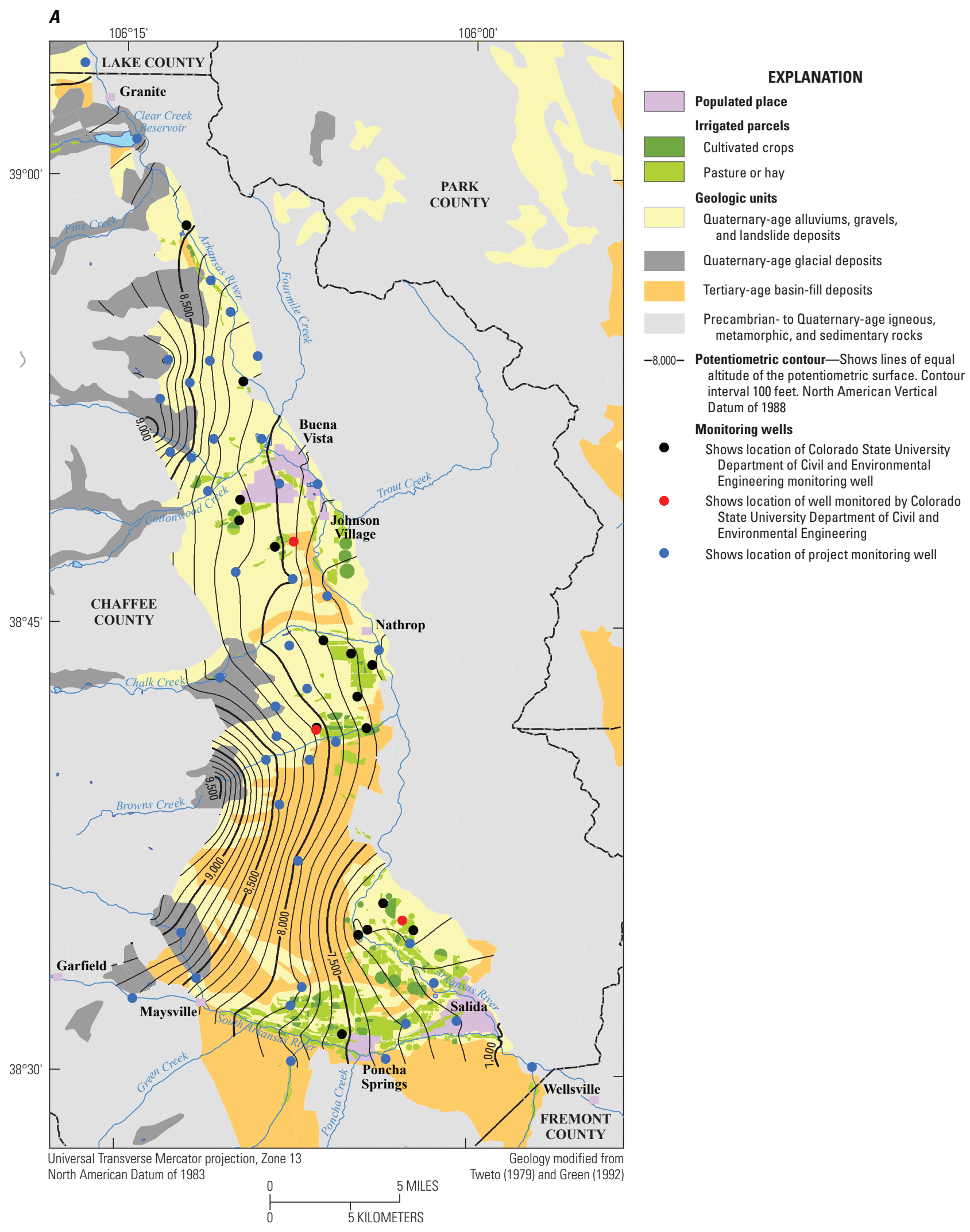

Figure 11. Generalized altitude and configuration of potentiometric surfaces in the Buena Vista-Salida Basin during A, March 2011 and $B$, June 2011; and $C$, estimated change in saturated thickness during March through June 2011. 


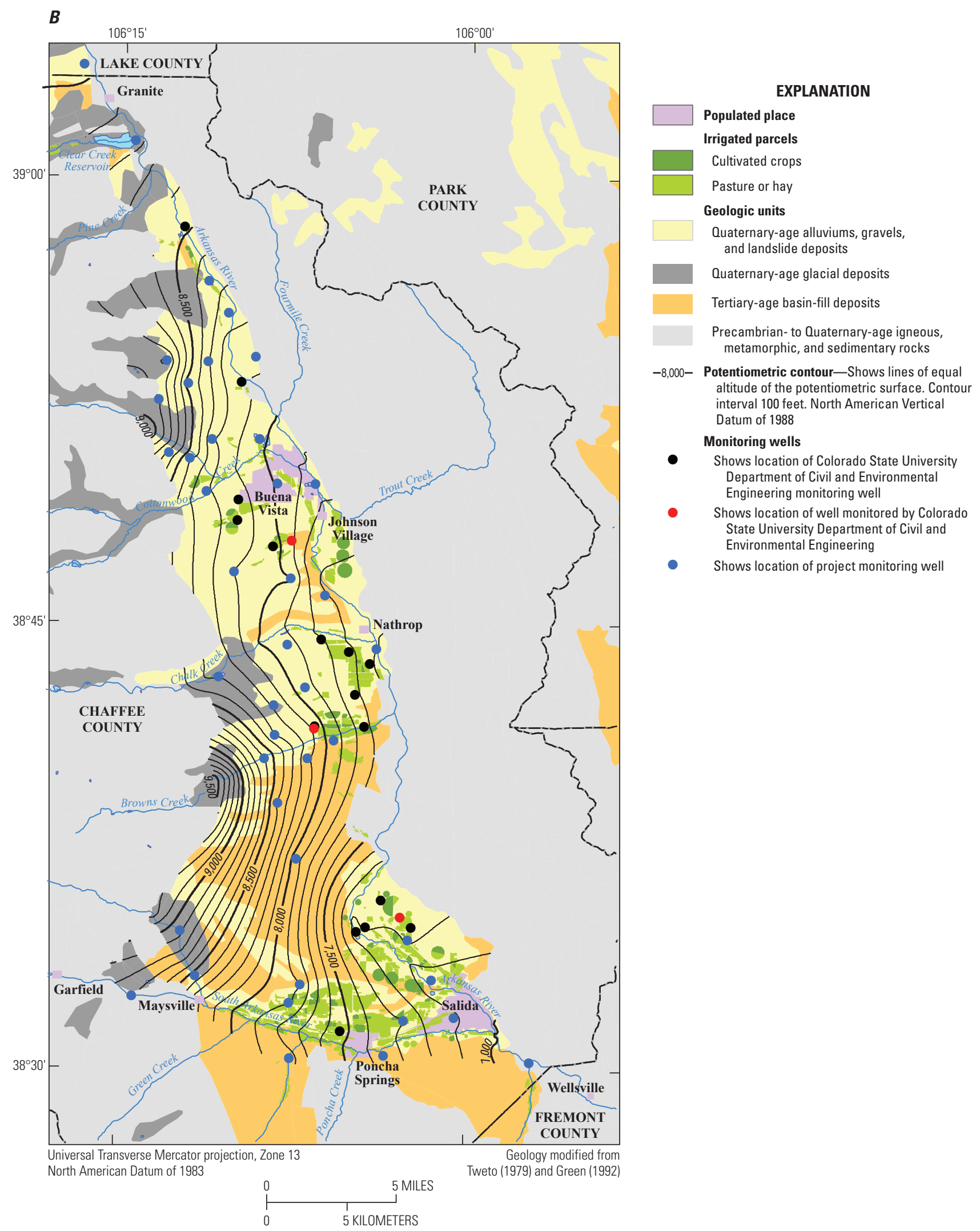

Figure 11. Generalized altitude and configuration of potentiometric surfaces in the Buena Vista-Salida Basin during A, March 2011 and $B$, June 2011; and $C$, estimated change in saturated thickness during March through June 2011.-Continued 


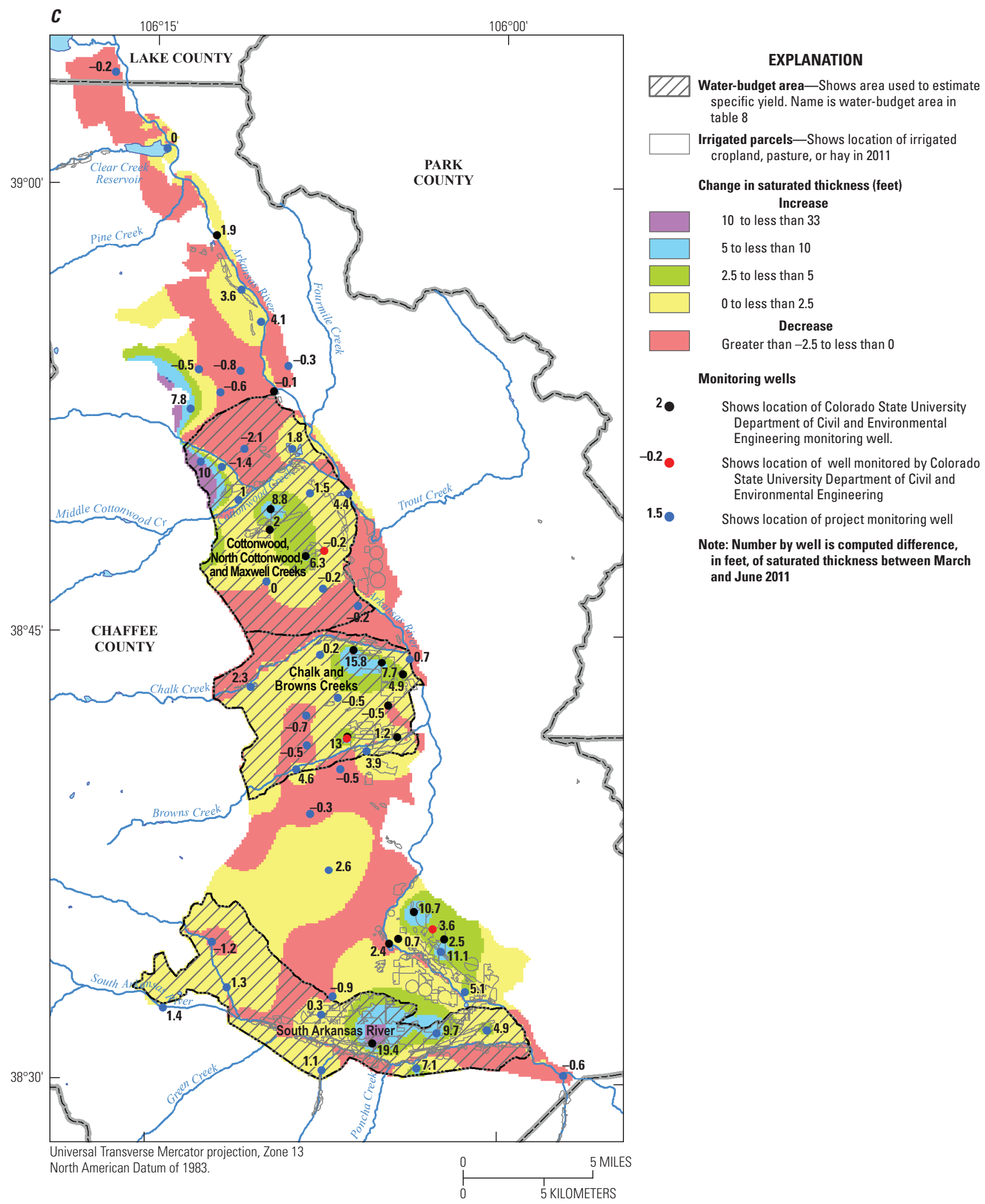

Figure 11. Generalized altitude and configuration of potentiometric surfaces in the Buena Vista-Salida Basin during A, March 2011 and $B$, June 2011; and $C$, estimated change in saturated thickness during March through June 2011.-Continued 
Table 8. Estimated changes in saturated thickness, water-budget estimates of groundwater recharge, and estimated specific yield in selected areas of the Buena Vista-Salida Basin, March through June 2011.

[Change in saturated volume estimated from difference between March 2011 and June 2011 groundwater-level measurements. Sum of non-negative values for potential recharge for the months March through June (tables 4, 5, 6, and 7)]

\begin{tabular}{lccccc}
\hline \multicolumn{1}{c}{ Water-budget area } & $\begin{array}{c}\text { Area } \\
\text { (acres) }\end{array}$ & $\begin{array}{c}\text { Average change } \\
\text { in saturated } \\
\text { thickness } \\
\text { (feet) }\end{array}$ & $\begin{array}{c}\text { Change in } \\
\text { saturated volume } \\
\text { (acre-feet) }\end{array}$ & $\begin{array}{c}\text { Estimated } \\
\text { recharge } \\
\text { (acre-feet) }\end{array}$ & $\begin{array}{c}\text { Estimated } \\
\text { area-weighted } \\
\text { specific vield } \\
\text { (dimensionless ratio) }\end{array}$ \\
\hline Cottonwood, North Cottonwood, and Maxwell Creeks & 28,180 & 1.192 & 33,590 & 4,990 & 0.15 \\
Chalk and Browns Creeks & 21,930 & 0.855 & 18,750 & 4,941 & 0.26 \\
South Arkansas River ${ }^{1}$ & 25,750 & 1.203 & 30,980 & 3,676 & 0.12 \\
\hline
\end{tabular}

${ }^{1}$ Includes recharge from irrigation in the Missouri Park district (shown in figure 3) that may not drain to the South Arkansas River.

\section{Potential Areas for Underground Storage}

Areas within the Buena Vista-Salida Basin with the potential for underground storage were identified using GIS data, including topographic, geologic, and hydrologic data. Mountainous areas that border the Buena Vista-Salida Basin and areas within the basin in which igneous and metamorphic rocks crop out were excluded from the analysis. Various properties of the surface and subsurface limit the potential for underground storage in a given area. Factors that commonly are considered when evaluating an area for underground storage include the following:

1. Slope of the land surface;

2. Soil erodibility;

3. Thickness, hydraulic, and storage properties of the soil;

4. Thickness, hydraulic, and storage properties of unsaturated zone and aquifer; and

5. Distances to flow boundaries, such as barriers, drains, and rivers.

The GIS layers (land-surface altitude, depth to water, geology, and soils) were used to identify areas in which (1) slope of land surface is not more than 3 percent, (2) depth to water below the surface is greater than $20 \mathrm{ft}$, (3) geologic materials at land surface consist of alluvial or alluvial-outwash deposits, and (4) soil at 60 inches below surface is relatively permeable. Factors 1, 2, and 3 generally apply to recharge projects that will use infiltration on or near the land surface. Those areas within the Buena Vista-Salida Basin that meet these criteria and may be suitable for artificial-storagerecovery projects are shown in figure 12 . In general, the areas that met the selection criteria are located on terrace deposits near the Arkansas River and adjacent to its major tributaries. The selected areas also contain much of the irrigated land within the basin (fig. 10); consequently, irrigation ditches and canals could provide a means of conveying water to potential recharge sites (fig. 12).

\section{Stream-Accretion Response-Time Factor}

In addition to the physical ability to accept water, it was desirable to know how long water recharged at a site will remain in storage before it is recovered or drains from the area in which it was stored. Although recharge in an unconfined aquifer that is hydraulically connected to surface water temporarily increases groundwater storage, it eventually will drain toward areas with lower hydraulic potential (streams and wetlands). The volume of recharge that is retained in storage decreases with time, as a function of the hydraulic and storage properties of the aquifer and the distances to downgradient discharge areas.

Numerical or analytical models commonly are used to quantify responses of hydraulically connected groundwater and surface-water systems to changes in recharge and discharge conditions. Although numerical models, such as MODFLOW (McDonald and Harbaugh, 1988) and its successors, are able to simulate complex conditions, including spatially variable aquifer properties, partially penetrating streams, and complex boundary conditions, they also require a good definition of the system to accurately predict system response. Analytical models can be relatively simple to apply and require substantially less data than numerical models but are limited to relatively simple geometries and by the assumptions on which they are based. Actual field conditions commonly violate the assumptions on which the analytical models are based, but analytical models still can provide a relative estimate of the amount of time for recharge at a point to affect nearby streamflow.

The stream depletion method of Jenkins (1968a, 1968b, $1968 \mathrm{c}$ ) is a simple analytical model that can be implemented in a GIS to estimate stream depletion or accretion that results from discharge from or recharge to an aquifer that is hydraulically connected to a stream. Data needed to calculate the stream-accretion response-time factor (saf) are the distance from the point of recharge to the stream and the storage coefficient (specific yield for unconfined aquifers) and transmissivity of the aquifer. Mathematically equivalent to the stream 


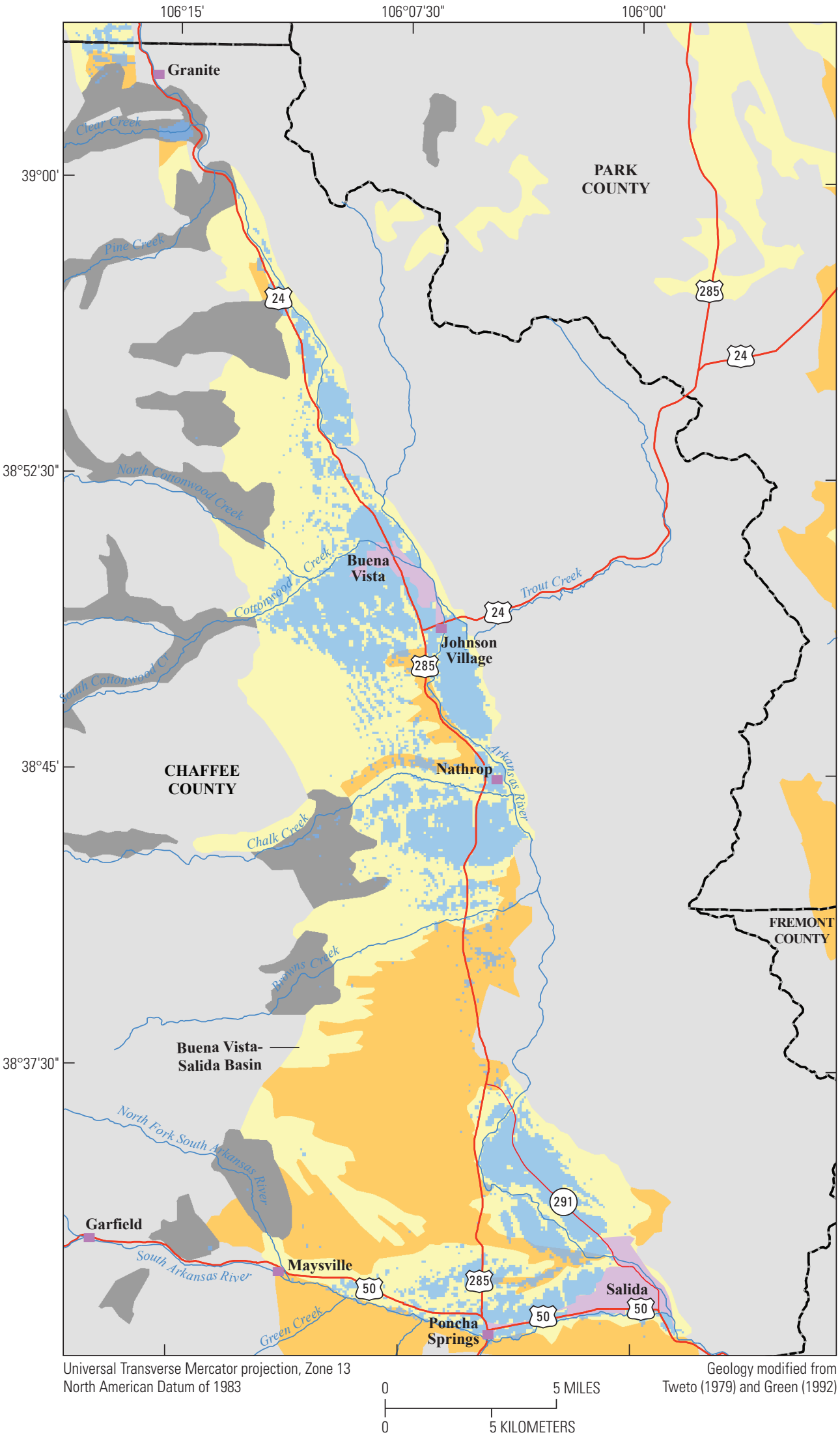

EXPLANATION

Populated place

Selected area-Shows area that meets criteria for potential recharge sites Geologic units

Quaternary-age alluviums, gravels, and landslide deposits

Quaternary-age glacial deposits

Tertiary-age basin-fill deposits

Precambrian- to Quaternary-age igneous, metamorphic, and sedimentary rocks

Figure 12. Selected areas within the Buena Vista-Salida Basin that may be suitable for artificial-storage-recovery projects. 
depletion factor (Jenkins, 1968a, 1968b, 1968c) caused by pumping wells but in the opposite direction, the saf for a particular recharge-site and streamflow-location pair reflects the combined effects of several factors, including the distance of the recharge site from the stream, the geometry of the aquifer system and stream network, and the hydraulic properties of the aquifer and streambed materials. Where an aquifer is connected to more than one stream, a saf is needed for each recharge-site and streamflow-location pair. Recharge at a site located near the Arkansas River and between two perennial tributary streams would accrete to the river and to both tributaries; thus, recharged water would not be retained in the aquifer for as long a period as that at a site not near perennial tributaries.

\section{Transmissivity and Specific Yield}

Transmissivity of the alluvial-outwash aquifer was assigned a uniform value of 500 meters squared per day $\left(\mathrm{m}^{2} / \mathrm{d}\right)\left(5,334\right.$ feet squared per day $\left.\left(\mathrm{ft}^{2} / \mathrm{d}\right)\right)$, which is about the average of reported transmissivity from three aquifer tests of the alluvial-outwash aquifer near Buena Vista (table 9). During these tests, groundwater levels in one or more monitoring wells were measured to determine groundwater-level responses to controlled rates of withdrawal by pumped (control) wells. Reported hydraulic-conductivity values from three aquifer tests of the alluvial-outwash aquifer near Buena Vista, Colo., ranged from about 116.5 to 231 feet per day (ft/d) or about 36 to 70 meter per day (m/d) (table 9). Transmissivity and hydraulic conductivity also were estimated from slug tests (table 10). Hydraulic-conductivity values from the slug tests (table 10) were more variable than those determined from aquifer (pumped well) tests (table 9). Hydraulic-conductivity values for the alluvial-outwash aquifer from slug tests ranged from about 0.19 to $190 \mathrm{ft} / \mathrm{d}$ (about 0.06 to $58 \mathrm{~m} / \mathrm{d}$ ) and for the basin-fill aquifer from about 2.2 to $210 \mathrm{ft} / \mathrm{d}(0.67$ to $64 \mathrm{~m} / \mathrm{d})$ (table 10). Results from the slug tests were not used in the saf analysis because the results of slug tests likely were affected substantially by well construction and development and potentially by measurement error. In very transmissive aquifers, the response to the instantaneous change of head may be so rapid that it is difficult to exactly define the initial change in height of the water column and the time at which the test began (Butler, 1998). Because the water-level responses in many of the slug tests done for this study were very rapid, less than a few seconds, and the transducer used for the tests could only record at a maximum frequency of 1 measurement per second, it was difficult to define the time and initial change in height of the water column. In those cases, however, the rapid water-level responses qualitatively indicate that the aquifer is very transmissive, greater than $2,000 \mathrm{ft}^{2} / \mathrm{d}$. A geostatistical analysis of hydraulic-conductivity values from the slug tests indicated that there was little spatial correlation in hydraulicconductivity values. Consequently, many additional sites would need to be tested to map spatial variation in hydraulic conductivity. The specific yield (Sy), which was estimated as the ratio of potential recharge and the change in saturated volume during March through June 2011 (table 8), of at least 0.18 , was rounded up to 0.2 for the saf analysis. The ratio $\mathrm{Sy} / \mathrm{T}$ is the inverse of hydraulic diffusivity (Lohman and others, 1972) and was assigned a constant value of 0.0004 day per square meter $\left(\mathrm{d} / \mathrm{m}^{2}\right)\left(0.0004 \mathrm{~d} / \mathrm{m}^{2}=0.2 \div 500 \mathrm{~m}^{2} / \mathrm{d}\right)$ or about 0.000024 day per square foot $\left(\mathrm{d} / \mathrm{ft}^{2}\right)$. Metric units for transmissivity (meter squared per day) were used in the analysis for convenience.

\section{Stream-Accretion Response-Time Maps}

The GIS was used to calculate the saf for all cells in the 100-m grid as follows:

$$
\text { saf }=\mathrm{d}^{2} \mathrm{Sy} / \mathrm{T}
$$

where

d is the distance from the point of recharge to the stream;

Sy is the specific yield, 0.2 ; and

$\mathrm{T}$ is the transmissivity, $500 \mathrm{~m}^{2} / \mathrm{d}$.

A composite map showing selected isochron (equal-time) contours of the saf for the nearest streams to the nodes (centers) of 100-m square grid cells is shown on figure 13. The saf was calculated for points (center of 100-m square grid cells) underlain by the alluvial-outwash and basin-fill aquifers that

Table 9. Reported results from aquifer tests of the alluvial-outwash aquifer in the Buena Vista-Salida Basin, Chaffee County, Colorado, 1992-2008.

[BVRU, Buena Vista Rearing Unit, Location coordinates estimated from written description (Romero, J.C., Colorado Division of Water Resources, written commun., 1993; NAD83, North American Datum of 1983]

\begin{tabular}{lllccccc}
\hline $\begin{array}{c}\text { Well or } \\
\text { site name }\end{array}$ & Date(s) of test & $\begin{array}{c}\text { Duration } \\
\text { of test } \\
\text { (hours) }\end{array}$ & $\begin{array}{c}\text { Latitude NAD83 } \\
\text { (decimal } \\
\text { degrees) }\end{array}$ & $\begin{array}{c}\text { Longitude NAD83 } \\
\text { (decimal } \\
\text { degrees) }\end{array}$ & $\begin{array}{c}\text { Aquifer } \\
\text { thickness } \\
\text { (feet) }\end{array}$ & $\begin{array}{c}\text { Transmissivity } \\
\text { (feet squared } \\
\text { per day) }\end{array}$ & $\begin{array}{c}\text { Hydraulic } \\
\text { conductivity } \\
\text { (feet per day) }\end{array}$ \\
\hline RMBH-2 & January 14-17, 2008 & 62.25 & 38.755250 & -106.075379 & 37.1 & 4,300 \\
BHBH-2 & January 17-20, 2008 & 63.3 & 38.762625 & -106.082206 & 38.1 & 6,700 \\
BVRU & February 13-14, 1992 & 23 & 38.8287 & -106.127 & 21.7 & 5,000 \\
\hline
\end{tabular}

${ }^{1}$ Pumped well did not fully penetrate aquifer. Source of data: ENSR | AECOM (2008) 
Table 10. Results from instantaneous-change-in-head (slug tests) of the alluvial-outwash and basin-fill aquifers in the Buena Vista-Salida Basin, Chaffee County Colorado, 2009.

[NAD83, North American Datum of 1983; MW, monitoring well; WS, water supply well]

\begin{tabular}{|c|c|c|c|c|c|c|c|c|c|c|}
\hline $\begin{array}{c}\text { Map number } \\
\text { (figure 10) }\end{array}$ & $\begin{array}{c}\text { Site } \\
\text { identification } \\
\text { number }\end{array}$ & $\begin{array}{l}\text { Latitude NAD83 } \\
\text { (decimal } \\
\text { degrees) }\end{array}$ & $\begin{array}{c}\text { Longitude NAD83 } \\
\text { (decimal } \\
\text { degrees) }\end{array}$ & $\begin{array}{l}\text { Date } \\
\text { of test }\end{array}$ & $\begin{array}{l}\text { Number } \\
\text { of tests }\end{array}$ & $\begin{array}{c}\text { Saturated } \\
\text { thickness } \\
\text { (feet) }\end{array}$ & $\begin{array}{c}\text { Transmissivity }{ }^{1} \\
\text { (feet squared } \\
\text { per day) }\end{array}$ & $\begin{array}{c}\text { Hydraulic }^{1} \\
\text { conductivity } \\
\text { (feet per day) }\end{array}$ & Aquifer & Well use \\
\hline $\mathrm{C} 01$ & 385820106122501 & 38.972292 & -106.207000 & 09/17/09 & 4 & 12 & 2,100 & 180 & Alluvial-outwash & MW \\
\hline $\mathrm{C} 02$ & 385605106105701 & 38.934673 & -106.182604 & 09/17/09 & 4 & 21 & 1,400 & 67 & Alluvial-outwash & MW \\
\hline S03 & 385348106111901 & 38.896778 & -106.188472 & 09/24/09 & 4 & 48 & 110 & 2.2 & Basin-fill & WS \\
\hline $\mathrm{C} 03$ & 385307106095101 & 38.885306 & -106.164194 & 09/17/09 & 4 & 16 & 210 & 13 & Alluvial-outwash & MW \\
\hline $\mathrm{C} 04$ & 384911106095701 & 38.819583 & -106.165917 & 09/17/09 & 4 & 18 & 900 & 50 & Alluvial-outwash & MW \\
\hline S06 & 384844106120301 & 38.812278 & -106.200944 & 09/22/09 & 4 & 59 & 1,100 & 18 & Alluvial-outwash & WS \\
\hline $\mathrm{C} 05$ & 384828106095801 & 38.807830 & -106.166191 & 09/17/09 & 2 & 9 & 220 & 24 & Alluvial-outwash & MW \\
\hline $\mathrm{C} 06$ & 384736106082501 & 38.793249 & -106.140218 & 09/22/09 & 4 & 24 & 1,500 & 62 & Basin-fill & MW \\
\hline $\mathrm{C} 07$ & 384429106061601 & 38.741375 & -106.104531 & 09/16/09 & 4 & 25 & 1,500 & 60 & Alluvial-outwash & MW \\
\hline $\mathrm{C} 08$ & 384403106050801 & 38.734201 & -106.085499 & 09/16/09 & 2 & 26 & 3,300 & 130 & Alluvial-outwash & MW \\
\hline $\mathrm{C} 09$ & 384340106041201 & 38.727819 & -106.070025 & 09/21/09 & 3 & 6 & 1,100 & 190 & Alluvial-outwash & MW \\
\hline $\mathrm{C} 10$ & 384238106045001 & 38.710475 & -106.080523 & 09/21/09 & 4 & 22 & 1,100 & 48 & Alluvial-outwash & MW \\
\hline $\mathrm{C} 11$ & 384134106042601 & 38.692639 & -106.074000 & 09/15/09 & 4 & 36 & 500 & 14 & Alluvial-outwash & MW \\
\hline $\mathrm{C} 12$ & 384126106062901 & 38.690675 & -106.108135 & 09/15/09 & 4 & 52 & 120 & 2.4 & Alluvial-outwash & MW \\
\hline $\mathrm{S} 15$ & 384040106082101 & 38.677711 & -106.139118 & 09/24/09 & 4 & 57 & 190 & 3.3 & Basin-fill & WS \\
\hline S16 & 383916106060501 & 38.654528 & -106.101444 & 09/15/09 & 1 & 38 & 1,900 & 49 & Alluvial-outwash & WS \\
\hline S17 & 383557106053401 & 38.599235 & -106.092659 & 09/22/09 & 4 & 53 & 11,0002 & 210 & Basin-fill & WS \\
\hline $\mathrm{C} 13$ & 383541106033901 & 38.594740 & -106.060824 & 09/14/09 & 3 & 24 & 3,100 & 130 & Basin-fill & MW \\
\hline $\mathrm{C} 14$ & 383446106021701 & 38.579472 & -106.038083 & 09/15/09 & 3 & 26 & 2,800 & 110 & Alluvial-outwash & MW \\
\hline C15 & 383443106041601 & 38.578701 & -106.071017 & 09/16/09 & 4 & 72 & 14 & 0.19 & Alluvial-outwash & MW \\
\hline $\mathrm{C} 16$ & 383438106043901 & 38.577187 & -106.077424 & 09/16/09 & 4 & 32 & 120 & 4 & Alluvial-outwash & MW \\
\hline $\mathrm{S} 22$ & 383359106030901 & 38.566367 & -106.052483 & 09/23/09 & 4 & 105 & 500 & 5 & Alluvial-outwash & WS \\
\hline $\mathrm{S} 23$ & 383342106032201 & 38.561784 & -106.056089 & 09/18/09 & 4 & 54 & 3,700 & 68 & Basin-fill & WS \\
\hline $\mathrm{S} 24$ & 383235106111901 & 38.543160 & -106.188506 & 09/23/09 & 4 & 60 & 720 & 12 & Alluvial-outwash & WS \\
\hline S25 & 383204106015401 & 38.534437 & -106.031690 & $09 / 24 / 09$ & 4 & 63 & 1,600 & 25 & Alluvial-outwash & WS \\
\hline S26 & 383153106063801 & 38.531468 & -106.110467 & 09/25/09 & 4 & 129 & 630 & 4.9 & Alluvial-outwash & WS \\
\hline S27 & 383138106020401 & 38.527306 & -106.034571 & 09/18/09 & 4 & 27 & 2,500 & 93 & Alluvial-outwash & WS \\
\hline $\mathrm{C} 17$ & 383117106051901 & 38.521449 & -106.088619 & 09/21/09 & 6 & 19 & 1,400 & 74 & Alluvial-outwash & MW \\
\hline S29 & 383037105593701 & 38.510349 & -105.993639 & 09/24/09 & 4 & 80 & 310 & 3.9 & Basin-fill & WS \\
\hline
\end{tabular}

'Values rounded to two significant digits.

${ }^{2}$ Value exceeds practical limit of test method. 


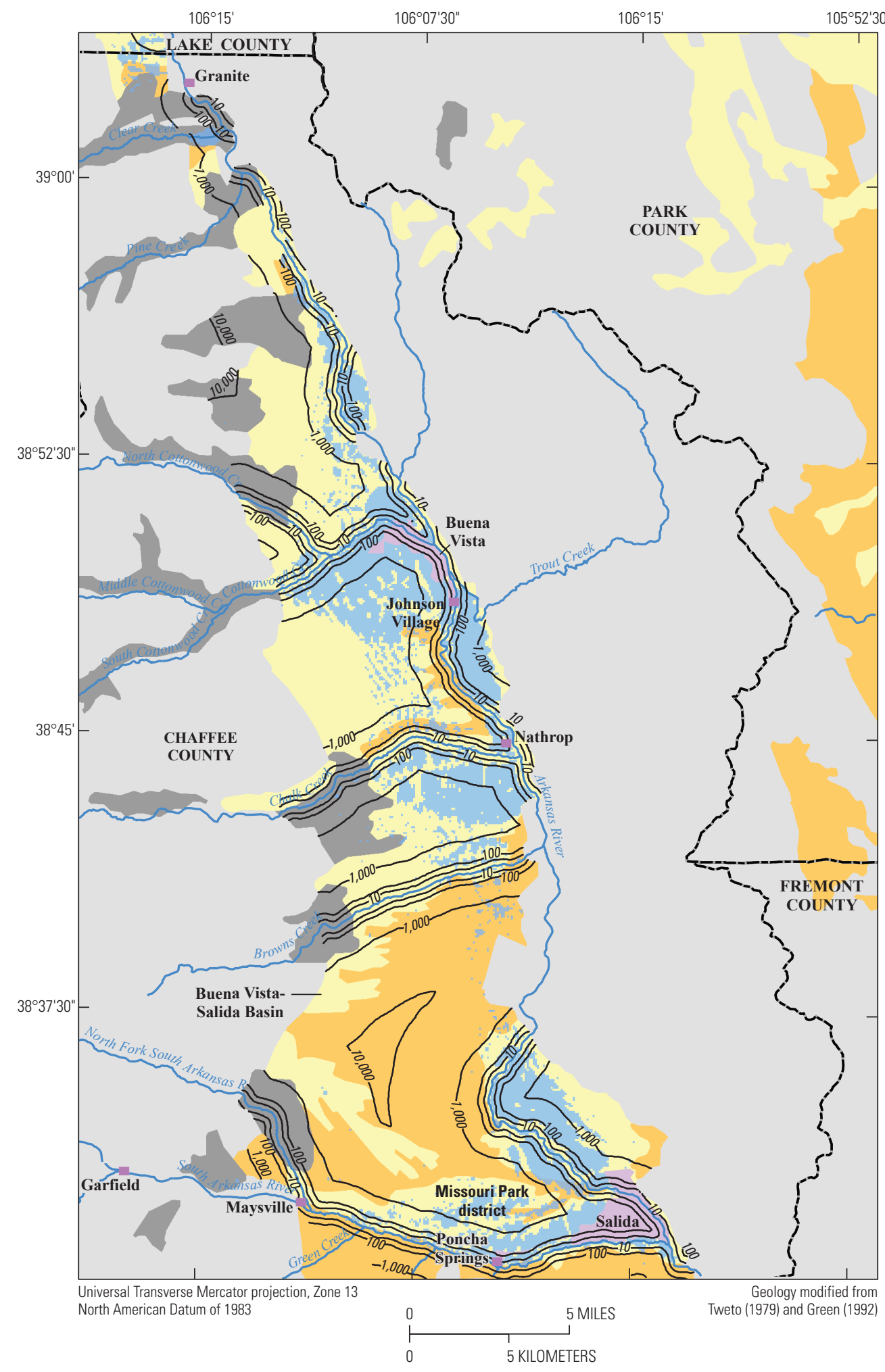

EXPLANATION

Populated place

Selected area-Shows area that meets criteria for potential recharge sites Geologic units

Quaternary-age alluviums, gravels, and landslide deposits

Quaternary-age glacial deposits

Tertiary-age basin-fill deposits

Precambrian- to Quaternary-age igneous, metamorphic, and sedimentary rocks

-100- Isochron-Shows line of equal streamaccretion response-time factor. Number is time in days for 28 percent of the volume of recharged water to accrete to the nearest stream. Contour interval is variable (logarithmic)

Figure 13. Composite stream-accretion response-time factors (saf) in the Buena Vista-Salida Basin. 
were within $10,000 \mathrm{~m}$ (about $6.2 \mathrm{mi}$ ) of selected streams. Contour values (isochrons) of the saf, which are the times, in days, at which the saf equals 1 and at which about 28 percent of the volume of recharged water would accrete to the nearest stream, are shown only for 10-, 100-, 1,000-, and 10,000-day isochrons. Where a potential recharge area lies near two or more streams, the accretion to each stream resulting from the recharge at a point needs to be considered. The saf for the Arkansas River is shown in figure 14 and the saf for Browns, Chalk, and Cottonwood Creeks, and the South Arkansas River is shown in figure 15. Multiplying an isochron value by 3 gives the time at which about 50 percent of the water has accreted to the stream, and by 15 , the time at which about 74 percent of the recharge has accreted to the nearest stream (Jenkins, 1968c).

If either the specific yield (Sy), the transmissivity (T), or both, are different than the values used in these analyses, a corrected saf can be calculated by multiplying the saf value by the ratio of the revised inverse of hydraulic diffusivity $(\mathrm{Sy} / \mathrm{T})$ and the original inverse of hydraulic diffusivity. For example, if the Sy is determined to be 0.15 , rather than 0.2 , and the transmissivity $\mathrm{T}$ is $5,334 \mathrm{ft}^{2} / \mathrm{d}\left(500 \mathrm{~m}^{2} / \mathrm{d}\right)$, the ratio of Sy/T would change from 0.000024 to $0.000018 \mathrm{~d} / \mathrm{ft}^{2}(0.0004$ to $0.0003 \mathrm{~d} / \mathrm{m}^{2}$ ), and the original saf value of 10 days would be revised to 7.5 days.

\section{Limitations of Analysis}

The limiting assumptions of the stream depletion factor method (Jenkins, 1968a, 1968b, 1968c) also are limiting assumptions for the saf method (see the "Methods" section of the report). Limiting assumptions that likely are violated by hydrogeologic conditions in the study area include the following:

1. The aquifer is homogeneous, isotropic, and extends to infinity away from the stream. Although hydraulic conductivity of the alluvial-outwash aquifer is not homogeneous, as indicated by the variability of hydraulicconductivity values (tables 9 and 10), there was no apparent spatial correlation in the variation in hydraulicconductivity values, thus the aquifers can be considered homogeneous in a statistical sense (constant mean with uniform spatial variance); however, the aquifers are not infinite in extent but are bounded by relatively impermeable rocks on the eastern and western sides of the basin. Thus, the saf likely is smaller than estimated near the sides of the basin.

2. The aquifer is confined, and its transmissivity and saturated thickness do not change with time. When the solution is also applied to an aquifer with unconfined conditions (a water table), it is assumed that mounding, or increase in saturated thickness, caused by injection or infiltration is small compared to the initial saturated thickness of the aquifer. Groundwater-level hydrographs in some parts of the basin (figs. 1-1 through 1-17) indicate that mounding as a result of infiltration of diversions may increase the saturated thickness by as much as 20 to 30 $\mathrm{ft}$. The increase in transmissivity values associated with increased saturated thickness could decrease the saf proportionately. Mounding caused by infiltration of artificial recharge should be managed so that groundwater levels are maintained at a sufficient depth below the land surface to prevent additional evapotranspiration losses.

3. The stream that forms a boundary with the aquifer is straight, fully penetrates the aquifer, is infinite in length, remains flowing at all times, and is in perfect hydraulic connection with the aquifer (that is, the streambed and streambed sediments do not impede flow between the stream and aquifer). Although the valleys of the perennial streams in the basin form relatively straight boundaries, it is likely that the streams only partially penetrate the alluvial-outwash aquifer, particularly near the mountain front on the western side of the basin. The effect of partial penetration would be to increase the saf.

Although numerical models of groundwater flow could provide more quantitative estimates of the residence time of water stored in the subsurface than the simple saf method, a better definition of subsurface conditions in the Buena VistaSalida Basin would be needed to support a numerical model. Better definition of the thickness of the alluvial-outwash aquifer and its distribution of hydraulic properties could improve prediction of the response of the stream-aquifer system to changes in recharge and discharge conditions that might occur as a result of aquifer-storage-recovery projects.

\section{Findings of the Potential for Underground Storage Analysis}

The Colorado Water Conservation Board (2007) ranked the Buena Vista-Salida Basin, specifically the alluvial-outwash aquifer, as one of the top 10 areas for underground (water) storage projects in the Arkansas River Basin. The quantity of water that can be recharged for storage projects is constrained by the hydrologic and physical properties of the aquifer, including those of the unsaturated material above the water table. Watts (2005) reported the alluvial-outwash aquifer in the study area to be hydraulically connected with streams; therefore, it is important to understand when and where water stored in the aquifer likely will discharge to receiving streams. Although economic, engineering, institutional, and legal factors must be considered in developing an artificial storage and recovery project, this analysis primarily is concerned with hydrologic factors limiting where the alluvial-outwash aquifer in the Buena Vista-Salida Basin has storage capacity and, if recharged, when water will discharge to streams. The relatively large seasonal fluctuations of groundwater near irrigated areas in the Buena Vista-Salida Basin indicate that the increased groundwater storage resulting from infiltration of surface-water diversions has dissipated by the following spring. 


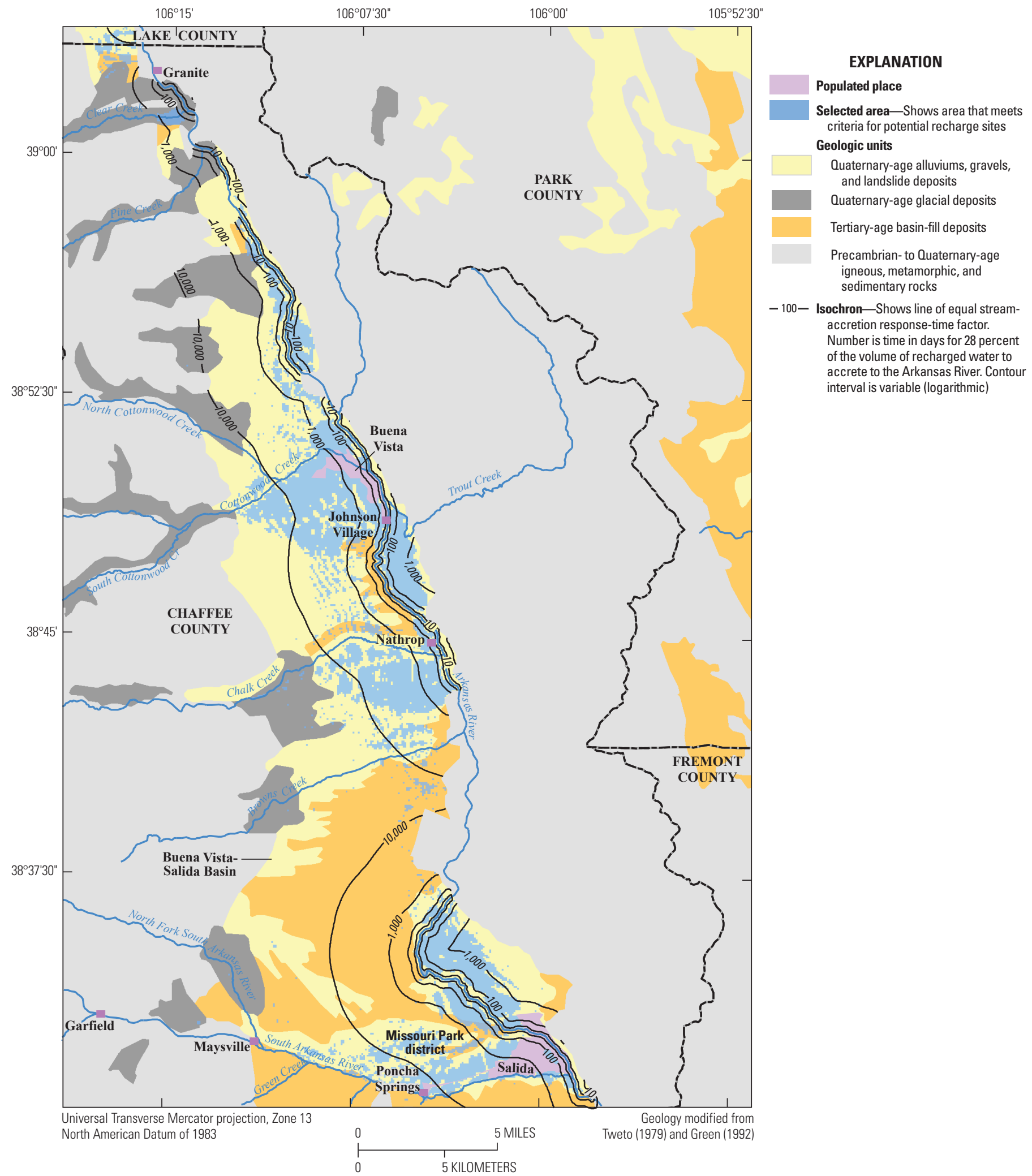

Figure 14. Stream-accretion response-time factors (saf) for the Arkansas River in the Buena Vista-Salida Basin. 


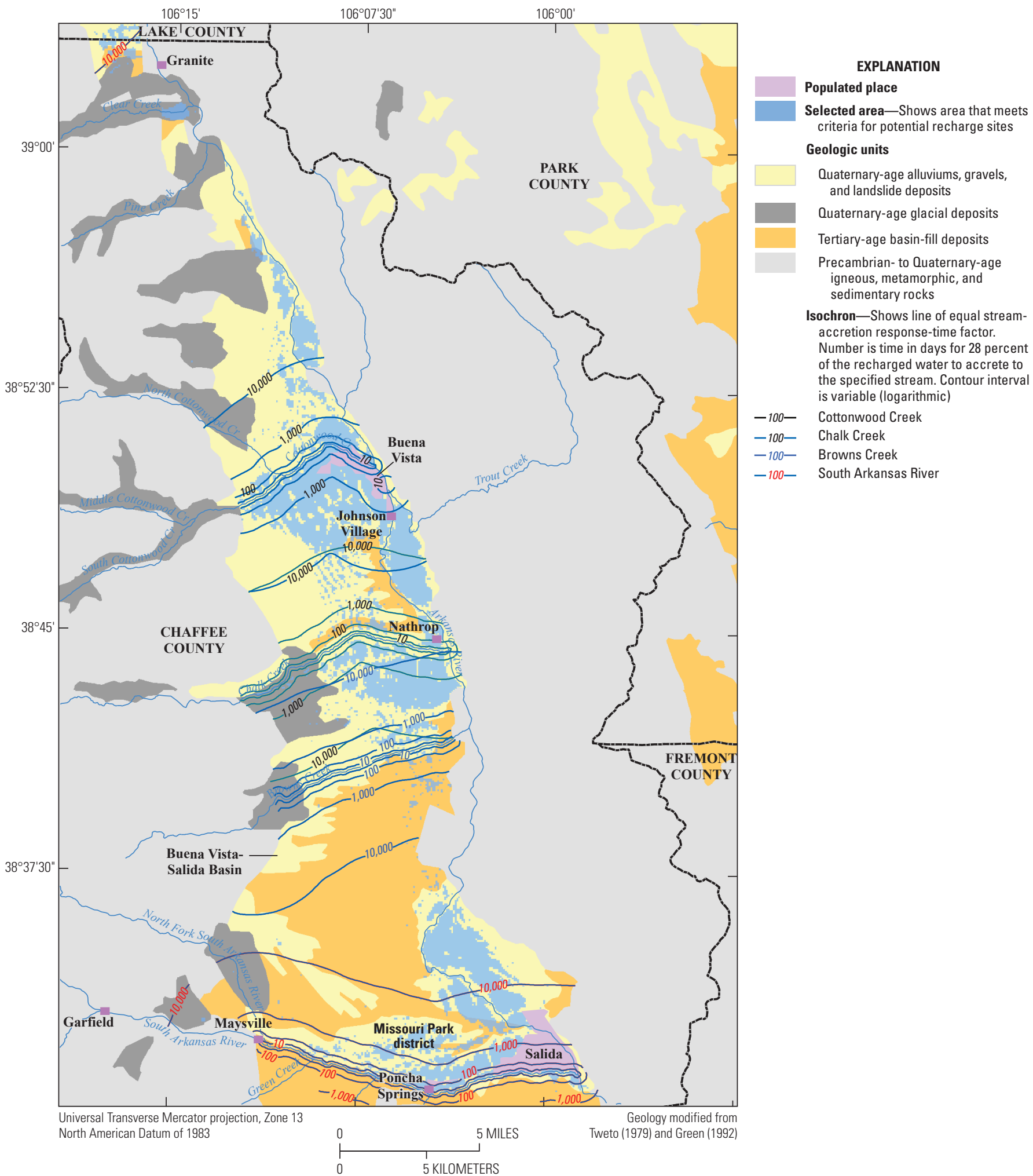

Figure 15. Stream-accretion response-time factors (saf) for Browns, Chalk, and Cottonwood Creeks, and the South Arkansas River in the Buena Vista-Salida Basin. 
Areas within the Buena Vista-Salida Basin with the potential for underground storage were identified using GIS data, including topographic, geologic, and hydrologic data, excluding the mountainous areas that border the areas in the Buena VistaSalida Basin where igneous and metamorphic rock crop out. Factors that commonly are considered when evaluating an area for underground storage include the slope of the land surface; soil erodibility; thickness, hydraulic, and storage properties of the soil; thickness, hydraulic, and storage properties of the unsaturated zone and aquifer; and distances to flow boundaries, such as barriers, drains, and rivers. The areas that met the selection criteria for underground water storage are located on terrace deposits near the Arkansas River and adjacent to its major tributaries. The selected areas also contain much of the irrigated land within the basin; consequently, irrigation ditches and canals with enough capacity could provide a means of conveying water to potential recharge sites.

Transmissivity $(\mathrm{T})$ of the alluvial-outwash aquifer was assigned a uniform value of $500 \mathrm{~m}^{2} / \mathrm{d}\left(5,334 \mathrm{ft}^{2} / \mathrm{d}\right)$, which is about the average of reported transmissivity from three aquifer tests of the alluvial-outwash aquifer near Buena Vista. The Sy, which was estimated as the ratio of potential recharge and the change in saturated volume during March through June 2011 of at least 0.18 , was rounded up to 0.2 for the saf analysis. The ratio Sy/T is the inverse of hydraulic diffusivity and was assigned a constant value of 0.0004 day per meter squared $\left(\mathrm{d} / \mathrm{m}^{2}\right)\left(0.0004 \mathrm{~d} / \mathrm{m}^{2}=0.2 \div 500 \mathrm{~m}^{2} / \mathrm{d}\right)$ or about $0.000024 \mathrm{~d} / \mathrm{ft}^{2}$.

If either the Sy, the $\mathrm{T}$, or both are different than the values used in these analyses, a corrected saf can be calculated multiplying the saf value by the ratio of the revised inverse of hydraulic diffusivity $(\mathrm{Sy} / \mathrm{T})$ and the original inverse of hydraulic diffusivity.

In the saf analysis of the Buena Vista-Salida Basin, there are a number of limiting assumptions. The hydraulic conductivity of the alluvial-outwash aquifer is not homogeneous, violating an assumption of the analysis; however, there was no apparent spatial correlation in the variation in hydraulicconductivity values, thus the aquifers can be considered homogeneous in a statistical sense (constant mean with uniform spatial variance). The alluvial-outwash and basin-fill aquifers are not infinite in extent but are bounded by relatively impermeable rocks on the eastern and western sides of the basin. Therefore, the saf likely is smaller than estimated near the sides of the basin. Groundwater-level hydrographs in some parts of the basin indicate that mounding as a result of infiltration of diversions may increase the saturated thickness by as much as 20 to 30 feet. The increase in transmissivity values associated with increased saturated thickness could decrease the saf proportionately. Although the valleys of the perennial streams in the basin form relatively straight boundaries, it is likely that the streams only partially penetrate the alluvialoutwash aquifer, particularly near the mountain front on the western side of the basin. The effect of partial penetration would be to increase the saf.
Numerical models of groundwater flow could provide better estimates of the residence time of water stored in the subsurface as a result of aquifer-storage-recovery projects than the simple saf method can; however, additional data to define subsurface conditions in the Buena Vista-Salida Basin would be needed to support a numerical model. Additional data that are needed to better define subsurface conditions of the alluvial-outwash aquifer include increased spatial definition of the aquifer's thickness and hydraulic properties.

\section{Summary}

By 2030, the population of the Arkansas Headwaters Region, which includes all of Chaffee and Lake Counties and parts of Custer, Fremont, and Park Counties, Colorado, is forecast to increase about 73 percent. As the region's population increases, it is anticipated that groundwater will be used to meet much of the increased demand. In September 2009, the U.S. Geological Survey, in cooperation with the Upper Arkansas Water Conservancy District and with support from the Colorado Water Conservation Board; Chaffee, Custer, and Fremont Counties; Buena Vista, Cañon City, Poncha Springs, and Salida; and Round Mountain Water and Sanitation District, began a 3-year study of groundwater and surfacewater conditions in the Buena Vista-Salida Basin. This report presents results from the study of groundwater and surfacewater interaction and potential for underground water storage in the Buena Vista-Salida Basin including synoptic gain-loss measurements and water budgets of Cottonwood, Chalk, and Browns Creeks, changes in groundwater storage, estimates of specific yield, transmissivity and hydraulic conductivity from aquifer tests and slug tests, an evaluation of areas with potential for underground water storage, and estimates of streamaccretion response-time factors for hypothetical recharge and selected streams in the basin.

Estimated annual base flow of the Arkansas River between Granite and Wellsville, Colo., during 1999-2011 averaged about 107,000 acre-feet (acre-ft) and ranged from a low of about 68,000 acre-ft during the drought of 2002 to 143,000 acre- $\mathrm{ft}$ during 1999. During 2010 and 2011, estimated annual base flow values were about 114,000 and 104,000 acre-ft, respectively. In addition to year-to-year variations in base flow, the base flow estimates vary seasonally with minimum and maximum values generally occurring during February and June, respectively.

The synoptic measurements conducted four times on Cottonwood, Chalk, and Browns Creeks suggest quantifiable groundwater gains and losses in selected segments in all three perennial streams. Even though for each stream there were a number of caveats to the analysis including streamflow measurements that were within the measurement error, inconsistent calculated gain or loss, or measurements that were are not available because of lack of access to the synoptic sites; the synoptics on Cottonwood and Browns Creeks suggest a 
seasonal variability. In the April 2011 synoptic, the overall sum of the gains and losses for each stream was negative, indicating that the streams were losing water before crop irrigation to the alluvial-outwash aquifer. In August and September synoptics, the overall sum of the gains and losses was positive. The positive later-irrigation season values in Cottonwood and Browns Creeks suggest groundwater discharge, possibly as infiltrated irrigation water. The calculated overall sum of gains and losses on Chalk Creek does not indicate a seasonal variability as does Cottonwood and Browns Creeks, but indicates a gaining stream in April and August/September. Gains and losses in the measured upper segments of Chalk Creek likely are affected by the Chalk Cliffs Rearing Unit (fish hatchery).

Monthly water budgets were estimated for selected segments of five perennial streams (Cottonwood, North Cottonwood, Chalk, and Browns Creeks, and South Arkansas River) in the Buena Vista-Salida Basin for calendar year 2011. Differences between reported diversions and estimated crop irrigation requirements were used to estimate groundwater recharge in the areas irrigated by water supplied from the diversions. In all basins (except for North Cottonwood), the surface-water budget was subdivided into an upper and lower segment, with usually a seasonal gage as the intermediate gage.

The net gain or loss calculated for the upper and lower segments of each of the basins indicates that if negative, the stream is losing water either to the groundwater system or by diversion, or if positive, suggesting groundwater discharge. The upper segment of Cottonwood Creek was calculated to be losing about 5,944 acre-ft whereas the lower segment was gaining 579 acre-ft, during April through October 2011. The upper segments of Chalk Creek and the South Arkansas River were calculated to be gaining segments, with groundwater discharging 3,819 acre-ft and 170 acre-ft, respectively. Lower segments in Chalk Creek and South Arkansas River were calculated to be a net loss, with 1,349 acre-ft and 8,941 acre-ft, respectively. Net gains for the upper and lower segments were calculated in Browns Creek, suggesting groundwater discharge in 2011 along the length of the study basin. The amount of groundwater recharge in all the basins varied monthly; however, the greatest amount of recharge occurred during June and July for Cottonwood, North Cottonwood, and Chalk Creeks and South Arkansas River. The greatest amount of recharge in 2011 in Browns Creek occurred in July and August.

The Colorado Water Conservation Board ranked the Buena Vista-Salida Basin, specifically the alluvial-outwash aquifer, as one of the top 10 areas for underground (water) storage projects in the Arkansas River Basin. The quantity of water that can be recharged for storage projects is constrained by the hydrologic and physical properties of the aquifer, including those of the unsaturated material above the water table. Because the alluvial-outwash aquifer in the study area is hydraulically connected with streams, it is important to understand when and where water stored in the aquifer likely will discharge to receiving streams. Although economic, engineering, institutional, and legal factors must be considered in developing an artificial storage and recovery project, this analysis primarily is concerned with hydrologic factors limiting where the alluvial-outwash aquifer in the Buena Vista-Salida Basin has storage capacity and, if recharged, when water will discharge to streams. The relatively large seasonal fluctuations of groundwater near irrigated areas in the Buena Vista-Salida Basin indicate that the increased groundwater storage resulting from infiltration of surface-water diversions has dissipated by the following spring.

Areas within the Buena Vista-Salida Basin with the potential for underground storage were identified using geographic information system data, including topographic, geologic, and hydrologic data, excluding the mountainous areas that border the Buena Vista-Salida Basin and igneous and metamorphic rock outcrop areas. Factors that commonly are considered when evaluating an area for underground storage include the slope of the land surface; soil erodibility; thickness, hydraulic, and storage properties of the soil; thickness, hydraulic, and storage properties of unsaturated zone and aquifer; and distances to flow boundaries, such as barriers, drains, and rivers. The areas that met the selection criteria for underground water storage are located on terrace deposits near the Arkansas River and adjacent to its major tributaries. The selected areas also contain much of the irrigated land within the basin; consequently, irrigation ditches and canals could provide a means of conveying water to potential recharge sites.

Transmissivity ( $\mathrm{T}$ ) of the alluvial-outwash aquifer was assigned a uniform value of $500 \mathrm{~m}^{2} / \mathrm{d}\left(5,334 \mathrm{ft}^{2} / \mathrm{d}\right)$, which is about the average of reported transmissivity from three aquifer tests of the alluvial-outwash aquifer near Buena Vista. The specific yield (Sy), which was estimated as the ratio of potential recharge and the change in saturated volume during March through June 2011 of at least 0.18 , was rounded up to 0.2 for the stream-accretion response-time factor (saf) analysis. The ratio Sy/T is the inverse of hydraulic diffusivity and was assigned a constant value of 0.0004 day per meter squared (d/ $\left.\mathrm{m}^{2}\right)\left(0.0004 \mathrm{~d} / \mathrm{m}^{2}=0.2 \div 500 \mathrm{~m}^{2} / \mathrm{d}\right)$ or about 0.000024 day per foot squared $\left(\mathrm{d} / \mathrm{ft}^{2}\right)$.

In the saf analysis of the Buena Vista-Salida Basin, there are a number of limiting assumptions. The hydraulic conductivity of the alluvial-outwash aquifer is not homogeneous, violating an assumption of the analysis; however, there was no apparent spatial correlation in the variation in hydraulicconductivity values, thus the aquifers can be considered homogeneous in a statistical sense (constant mean with uniform spatial variance). The alluvial-outwash and basin-fill aquifers are not infinite in extent but are bounded by relatively impermeable rocks on the eastern and western sides of the basin. Therefore, the saf likely are smaller than estimated near the sides of the basin. Groundwater-level hydrographs in some parts of the basin indicate that mounding as a result of infiltration of diversions may increase the saturated thickness by as much as 20 to 30 feet. The increase in transmissivity values associated with increased saturated thickness could decrease the saf proportionately. Although the valleys of the perennial 
streams in the basin form relatively straight boundaries, it is likely that the streams only partially penetrate the alluvialoutwash aquifer, particularly near the mountain front on the western side of the basin. The effect of partial penetration would be to increase the saf.

Although numerical models of groundwater flow could provide more quantitative estimates of the residence time of water stored in the subsurface than the simple saf method, a more accurate definition of subsurface conditions in the Buena Vista-Salida Basin would be needed to support a numerical model. A more accurate definition of the thickness of and distribution of hydraulic properties in the alluvial-outwash aquifer could improve prediction of the response of the stream-aquifer system to changes in recharge and discharge conditions that could occur as a result of aquifer-storagerecovery projects.

\section{Acknowledgments}

This study could not have been conducted without the support and cooperation of numerous individual and organizations. Appreciation is expressed to the many property and well owners in Chaffee County who allowed access to their property to measure streams, ditches, and wells. The following organizations provided data or access for measurements:

- Colorado State University, Department of Civil and Environmental Engineering, Fort Collins, Colo.Dr. Timothy K. Gates, Professor, and Mr. Greg Steed provided construction and groundwater-level data and access to monitoring wells for slug tests.

- Colorado Division of Water Resources-Mr. Bruce Smith, District 11 Water Commissioner, and Mr. David Kelly, District 11 Deputy Water Commissioner, provided orientation to diversion structures in the study area and diversion records.

- Mr. Ivan Walter of Ivan's Engineering, Inc., Littleton, Colo., consultant to the Upper Arkansas Water Conservancy District (UAWCD), provided information and suggestions about computation of crop irrigation requirements.

- Mr. Jord Gertson, Source Water, Inc., Buena Vista, Colo., consultant to the UAWCD, provided data for UAWCD's streamgages.

- City of Buena Vista, Colo.-Mr. Roy Gertson, granted access to measure streamflow diversions and provided municipal water-use data. The Cities of Salida and Poncha Springs also provided municipal water-use data.

- Chaffee County-Mr. Don Reimer, Chaffee County Development Director, provided GIS data for land use and locations of irrigation canals and ditches in Chaffee County.

\section{References Cited}

Allen, R.G., and Wright, J.L., 2002, Conversion of Wright (1981) and Wright (1982) alfalfa-based crop coefficients for use with the ASCE Standardized Penman-Montieth Reference Evapotranspiration Equation: Technical Note in ASCE Manual 70, 38 p., accessed April 12, 2013, at http://www.kimberly.uidaho.edu/water/asceewri/ Conversion_of_Wright_Kcs_2c.pdf.

American Society of Civil Engineers, 1996, Hydrology handbook (Manual of Practice No. 28) (2d ed.): New York, American Society of Civil Engineers, 784 p.

American Society of Civil Engineers, 2005, The ASCE standardized reference evapotranspiration equation: Task Committee on Standardization of Reference Evapotranspiration, Environmental and Water Resources Institute, p. 59, accessed September 17, 2012, at http://www.kimberly. uidaho.edu/water/asceewri/ascestzdetmain2005.pdf.

Barlow, P.M., and Leake, S.A., 2012, Streamflow depletion by wells-Understanding and managing the effects of groundwater pumping on streamflow: U.S. Geological Survey Circular 1376, 84 p.

Buena Vista City Data, 2011, Buena Vista Colorado City Data: accessed October 27, 2011, at http://www.city-data.com/ city/Buena-Vista-Colorado.html.

Butler, J.J., Jr., 1998, The design, performance, and analysis of slug tests: Boca Raton, Lewis Publishers, 252 p.

Colorado Division of Local Government, 2011, 2010 Census data for Colorado: accessed January 10, 2011, at http://dola. colorado.gov/dlg/demog/2010censusdata.html.

Colorado Division of Water Resources, 2011, HydroBase: accessed September 9, 2011, at http://www.dwr.state.co.us/ HBGuestExport/HBGuestExport.aspx.

Colorado Division of Water Resources, 2012, HydroBase: accessed October 24, 2012, at http://www.dwr.state.co.us/ HBGuestExport/HBGuestExport.aspx.

Colorado Division of Water Resources, 2013a, Residential water well permit application: accessed September 13, 2013, at http://water.state.co.us/DWRIPub/Documents/ gws-44.pdf.

Colorado Division of Water Resources, 2013b, Prior Appropriation Law: accessed October 10, 2013, at http://water.state. co.us/SurfaceWater/SWRights/Pages/PriorApprop.aspx.

Colorado State University, 2011, Colorado Agricultural Meteorological network: accessed December 10, 2011, at http://www.coagmet.colostate.edu. 
Colorado Water Conservation Board, 2004, Statewide water supply initiative: Denver, Colo., Colorado Water Conservation Board, accessed January 16, 2009, at http://cwcbweblink.state.co.us/WebLink/ElectronicFile. aspx? docid $=144066 \&$ searchid $=2 c 16 c 041-d 0 b 2-4 e c 5-a c 42-$ $8 b 95 a a 0 c 04 e 3 \& d b i d=0$.

Colorado Water Conservation Board, 2007, SB06-193 Underground water storage study: Denver, Colo., Colorado Water Conservation Board, accessed January 16, 2009, at http:// cwcbweblink.state.co.us/weblink/0/doc/144062/Electronic. aspx? searchid $=31104 c 98-5 f f a-4943-84 d 1-03 e b 4 b 0 a f 323$.

Crouch, T.M., Cain, Doug, Abbott, P.O., Penley, R.D., and Hurr, R.T., 1984, Water-resources appraisal of the upper Arkansas River Basin from Leadville to Pueblo, Colorado: U.S. Geological Survey Water-Resources Investigations Report 82-4114, 123 p.

Cunningham, W.L., and Schalk, C.W., comps., 2011, Groundwater technical procedures of the U.S. Geological Survey: U.S. Geological Survey Techniques and Methods, book 1, chap. A1, 151 p. (Available only online at http://pubs.usgs.gov/tm/1a1/.)

Duffield, G.M., 2004-2007, AQTESOLV for Windows, version 4.5 user's guide: Reston Va., HydroSOLVE, Inc., $529 \mathrm{p}$.

ENSR|AECOM, 2008, Phase I hydrogeologic report for the Buena Vista Spring sites-Revised draft: Fort Collins, Colo., 491 p.

Environmental Systems Research Institute, Inc., variously dated, ArcGIS $\odot$ and ArcMap ${ }^{\mathrm{TM}}$ : Redlands, Calif.

Freeze, R.A., and Cherry, J.A., 1979, Groundwater: Englewood Cliffs, N.J., Prentice-Hall, Inc., 604 p.

Glover, R.E., and Balmer, G.G., 1954, River depletion resulting from pumping a well near a river: Transactions of the American Geophysical Union, v. 35, no. 3, p. 468-470.

Green, G.N., 1992, The digital geologic map of Colorado in ARC/INFO format: U.S. Geological Survey Open-File Report 92-0507. (Also available at URL http://pubs.usgs. gov/of/1992/ofr-92-0507/.)

Healy, R.W., Winter, T.C., LaBaugh, J.W., and Franke, O.L., 2007, Water budgets - Foundations for effective waterresources and environmental management: U.S. Geological Survey Circular 1308, 90 p.

Helsel, D.R., and Hirsch, R.M., 2002, Statistical methods in water resources: U.S. Geological Survey Techniques of Water-Resources Investigations, book 4, chap. A3, 510 p.

Ivahnenko, Tamara, and Flynn, J.L., 2010, Estimated withdrawals and use of water in Colorado, 2005: U.S. Geological Survey Scientific Investigations Report 2010-5002, 61 p.
Jenkins, C.T., 1968a, Techniques for computing rate and volume of stream depletion by wells: Ground Water, v. 6, no. 2, p. $37-46$.

Jenkins, C.T., 1968b, Electric-analog and digital-computer model analysis of stream depletion by wells: Ground Water, v. 6 , no. 6 , p. $27-34$.

Jenkins, C.T., 1968c, Computation of rate and volume of stream depletion by wells: U.S. Geological Survey Techniques of Water-Resources Investigations, book 4, chap. D1, $17 \mathrm{p}$.

Lohman, S.E., and others, 1972, Definitions of selected ground-water terms-Revisions and conceptual refinements: U.S. Geological Survey Water-Supply Paper 1988, $21 \mathrm{p}$.

McDonald, M.G., and Harbaugh, A.W., 1988, A modular three-dimensional finite-difference ground-water flow model: U.S. Geological Survey Techniques of WaterResources Investigations, book 6, chap. A1, 586 p.

National Agricultural Statistics Service, 2012, 2011 Cropland data layer: accessed July 9, 2012, at http://www.nass.usda. gov/research/Cropland/SARS1a.htm.

National Agricultural Statistics Service, 2010, Colorado agricultural statistics: accessed October 27, 2011, at $h t t p: / /$ www.nass.usda.gov/Statistics_by_State/Colorado/index.asp.

Olea, R.A., 1984, Sampling design optimization for spatial functions: Mathematical Geology, v. 16, no. 4, p. 369-392.

Rantz, S.E., and others, 1982, Measurement and computation of streamflow-Volume 2, Computation of discharge: U.S. Geological Survey Water-Supply Paper 2175, 347 p.

Seidl, Andrew, 2007, Chaffee County economic development report: Colorado State University, Department of Agricultural and Resource Economics, EDR-07-13, p. 14.

Soil Survey Staff, Natural Resources Conservation Service, U.S. Department of Agriculture, 2013, Soil Survey Geographic (SSURGO) database for Chaffee, Fremont, Lake, and Saguache Counties, Colorado: (Also available at URL http://soildatamart.nrcs.usda.gov.)

Theis, C.V., 1935, The relation between the lowering of the piezometric surface and the rate and duration of discharge of a well using ground-water storage: American Geophysical Union Transactions, 16th Annual Meeting, v. 16, pt. 2, p. 519-524.

Turnipseed, D.P., and Sauer, V.B., 2010, Discharge measurements at gaging stations: U.S. Geological Survey Techniques and Methods, book 3, chap. A8, 87 p. (Also available at URL http://pubs.usgs.gov/tm/tm3-a8/.) 
Tweto, Ogden, 1961, Late Cenozoic events of the Leadville district and upper Arkansas Valley, Colorado, in Short papers in the geologic and hydrologic sciences, articles 1-146: U.S. Geological Survey Professional Paper 424-B, p. 133-135.

Tweto, Ogden, 1979, Geologic map of Colorado: U.S. Geological Survey State Geologic Map, scale 1:500,000.

Tweto, Ogden, and Case, J.E., 1972, Gravity and magnetic features as related to geology in the Leadville 30-minute quadrangle, Colorado: U.S. Geological Survey Professional Paper 726-C, $30 \mathrm{p}$.

U.S. Department of Agriculture, 2011, National Agricultural Imagery Program: accessed at http://datagateway.nrcs.usda.gov/.

U.S. Environmental Protection Agency, 2011, Enforcement and compliance history online (ECHO): accessed September 12, 2011, at http://www.epa-echo.gov/echo/ compliance_report_water.html.
U.S. Geological Survey, 2008, TCMA digital elevation model, 10 meter: accessed June 29, 2010, at http://ned.usgs.gov.

Van Slyke, G., and Simpson, H., 1974, Consumptive use of water by homes utilizing leach fields for sewage disposal: Colorado Division of Water Resources, Memorandum to the State Engineer, 5 p.

Watts, K.R., 2005, Hydrogeology and quality of ground water in the upper Arkansas River Basin from Buena Vista to Salida, Colorado, 2000-2003: U.S. Geological Survey Scientific Investigations Report 2005-5179, 61 p., available at http://pubs.usgs.gov/sir/2005/5179/.

Western Regional Climate Center, 2011, Buena Vista, Colorado (051071) climatological summaries: accessed October 27, 2011, at http://www.wrcc.dri.edu/cgi-bin/ cliMAIN.pl?co1071. 
Appendix 
Table 1-1. Summary of synoptic measurements of Cottonwood, Chalk, and Browns Creeks and calculated gains and losses, August 9-11 and September 8-10, 2010, and April 27-29 and August 23-25, 2011.

[Station names are listed in table 2. Net gain is a positive value and net loss is a negative value; values in red are diversions; values in blue are tributary or seep inflow or return flow; italicized values are reported values; *, water diverted out of drainage basin; NA, not available]

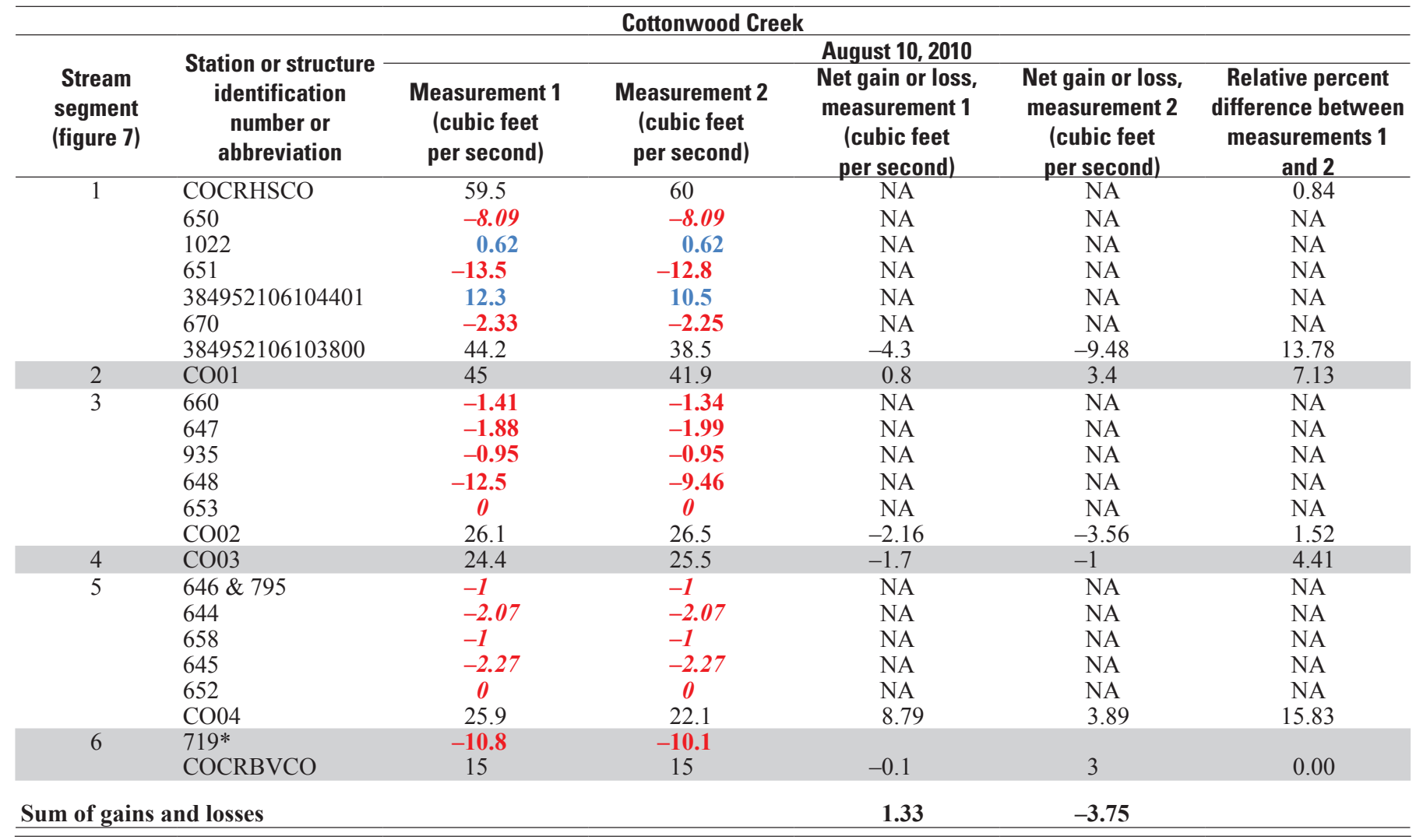

\begin{tabular}{|c|c|c|c|c|c|c|}
\hline \multicolumn{7}{|c|}{ Cottonwood Creek-Continued } \\
\hline \multirow[b]{2}{*}{$\begin{array}{c}\text { Stream } \\
\text { segment } \\
\text { (figure 7) }\end{array}$} & \multirow[b]{2}{*}{$\begin{array}{l}\text { Station or structure } \\
\text { identification } \\
\text { number or } \\
\text { abbreviation }\end{array}$} & \multicolumn{5}{|c|}{ September 8, 2010} \\
\hline & & $\begin{array}{l}\text { Measurement } 1 \\
\text { (cubic feet } \\
\text { per second) }\end{array}$ & $\begin{array}{l}\text { Measurement } 2 \\
\text { (cubic feet } \\
\text { per second) }\end{array}$ & $\begin{array}{c}\text { Net gain or loss, } \\
\text { measurement } 1 \\
\text { (cubic feet } \\
\text { per second) }\end{array}$ & $\begin{array}{c}\text { Net gain or loss, } \\
\text { measurement } 2 \\
\text { (cubic feet } \\
\text { per second) }\end{array}$ & $\begin{array}{c}\text { Relative percent } \\
\text { difference between } \\
\text { measurements } 1 \\
\text { and } 2\end{array}$ \\
\hline \multirow[t]{5}{*}{1} & COCRHSCO & 31.60 & 30.30 & NA & NA & 4.20 \\
\hline & 651 & -1.1 & -0.93 & NA & NA & NA \\
\hline & 384952106104401 & 10.2 & 10.3 & NA & NA & NA \\
\hline & 670 & -1.5 & -1.61 & NA & NA & NA \\
\hline & 384952106103800 & 32.3 & 32.3 & 0.52 & 1.66 & 0.00 \\
\hline 2 & $\mathrm{CO} 01$ & 32.5 & 35.1 & 0.2 & 2.8 & 7.69 \\
\hline 3 & 660 & $\mathbf{0}$ & $\mathbf{0}$ & NA & NA & NA \\
\hline 4 & $\mathrm{CO} 03$ & 19.4 & 18.8 & 1.4 & -1.6 & 3.14 \\
\hline \multirow[t]{6}{*}{5} & $646 \& 795$ & -1.5 & -1.56 & NA & NA & NA \\
\hline & 644 & -1.93 & -1.93 & NA & NA & NA \\
\hline & 658 & 0 & 0 & NA & NA & NA \\
\hline & 645 & -2.4 & -2.4 & NA & NA & NA \\
\hline & 652 & 0 & 0 & NA & NA & NA \\
\hline & $\mathrm{CO} 04$ & 13.3 & 12.6 & 1.17 & 1.13 & 5.41 \\
\hline \multirow[t]{2}{*}{6} & $719 *$ & -9.92 & -10.6 & & & \\
\hline & COCRBVCO & 1.77 & 2.92 & -1.61 & 0.92 & 49.04 \\
\hline \multicolumn{2}{|c|}{ Sum of gains and losses } & & & 1.76 & 2.42 & \\
\hline
\end{tabular}


Table 1-1. Summary of synoptic measurements of Cottonwood, Chalk, and Browns Creeks and calculated gains and losses, August 9-11 and September 8-10, 2010, and April 27-29 and August 23-25, 2011.-Continued

[Station names are listed in table 2. Net gain is a positive value and net loss is a negative value; values in red are diversions; values in blue are tributary or seep inflow or return flow; italicized values are reported values;*, water diverted out of drainage basin; NA, not available]

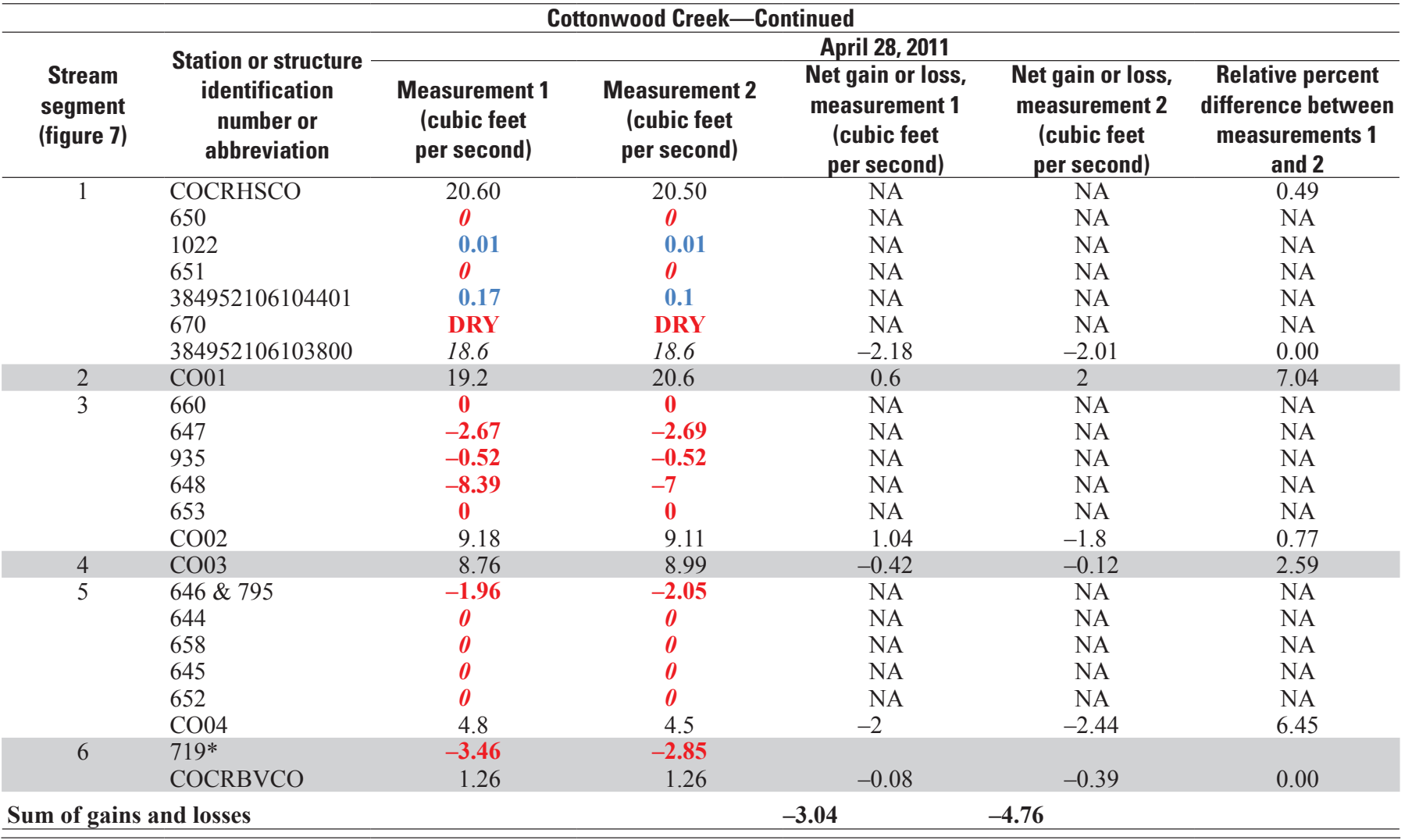

Sum of gains and losse

Cottonwood Creek-Continued

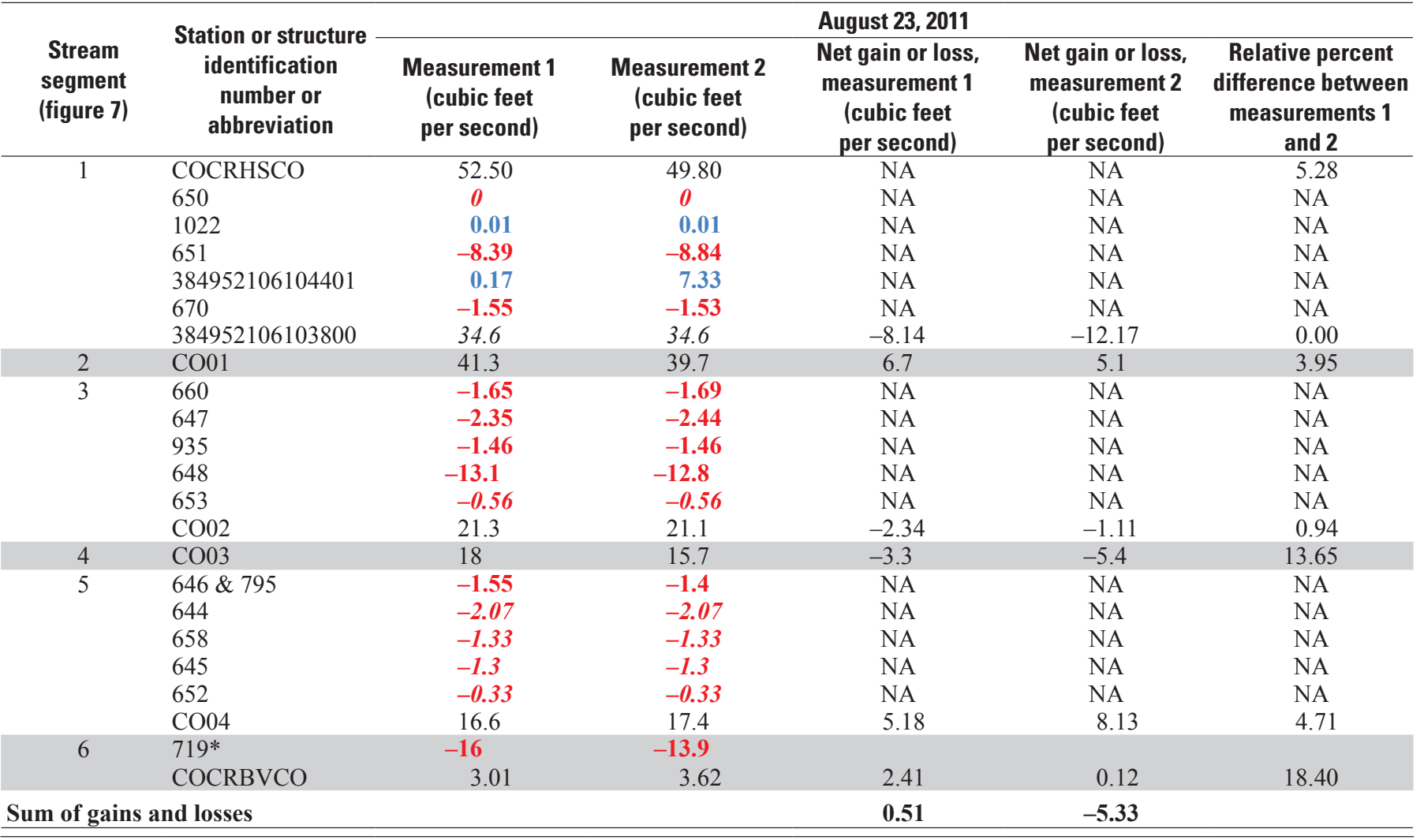


Table 1-1. Summary of synoptic measurements of Cottonwood, Chalk, and Browns Creeks and calculated gains and losses, August 9-11 and September 8-10, 2010, and April 27-29 and August 23-25, 2011.-Continued

[Station names are listed in table 2. Net gain is a positive value and net loss is a negative value; values in red are diversions; values in blue are tributary or seep inflow or return flow; italicized values are reported values; ${ }^{*}$, water diverted out of drainage basin; NA, not available]

\begin{tabular}{|c|c|c|c|c|c|c|}
\hline \multicolumn{7}{|c|}{ Chalk Creek } \\
\hline $\begin{array}{c}\text { Stream } \\
\text { segment } \\
\text { (figure 8) }\end{array}$ & $\begin{array}{l}\text { Station or structure } \\
\text { identification } \\
\text { number or } \\
\text { abbreviation }\end{array}$ & \multicolumn{5}{|c|}{ August 9, 2010} \\
\hline \multirow[t]{2}{*}{1} & 384407106090901 & 86.6 & 79.5 & NA & NA & 8.55 \\
\hline & 2071 & -10 & -10 & NA & NA & NA \\
\hline \multirow[t]{4}{*}{3} & 684 & 0 & 0 & NA & NA & NA \\
\hline & $\mathrm{CH} 03$ & -9.84 & -11.3 & NA & NA & NA \\
\hline & $\mathrm{CH} 04$ & 4.15 & 4.71 & NA & NA & NA \\
\hline & 384458106073901 & 75.4 & 70.8 & -1.95 & -5.21 & 6.29 \\
\hline 4 & $\mathrm{CH} 05$ & 0 & 0 & NA & NA & NA \\
\hline 5 & 695 & -3 & -3 & NA & NA & NA \\
\hline \multirow[t]{2}{*}{7} & 688 & -11 & -11 & NA & NA & NA \\
\hline & CHCRNACO & 62 & 65.1 & 7 & 14.7 & 4.88 \\
\hline \multicolumn{4}{|c|}{ Sum of gains and losses } & 1.65 & 11.29 & \\
\hline
\end{tabular}

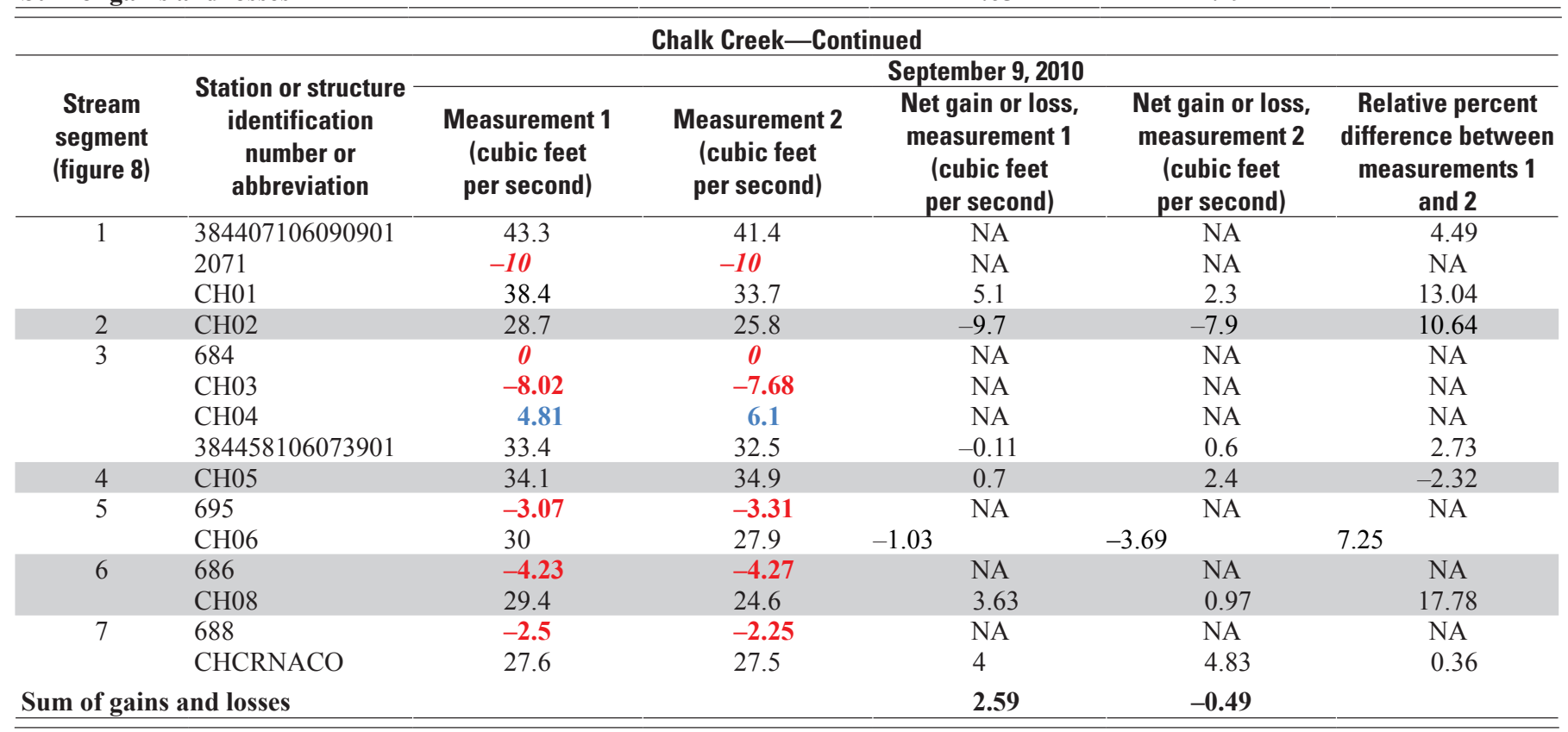


Table 1-1. Summary of synoptic measurements of Cottonwood, Chalk, and Browns Creeks and calculated gains and losses, August 9-11 and September 8-10, 2010, and April 27-29 and August 23-25, 2011.-Continued

[Station names are listed in table 2. Net gain is a positive value and net loss is a negative value; values in red are diversions; values in blue are tributary or seep inflow or return flow; italicized values are reported values; ${ }^{*}$, water diverted out of drainage basin; NA, not available]

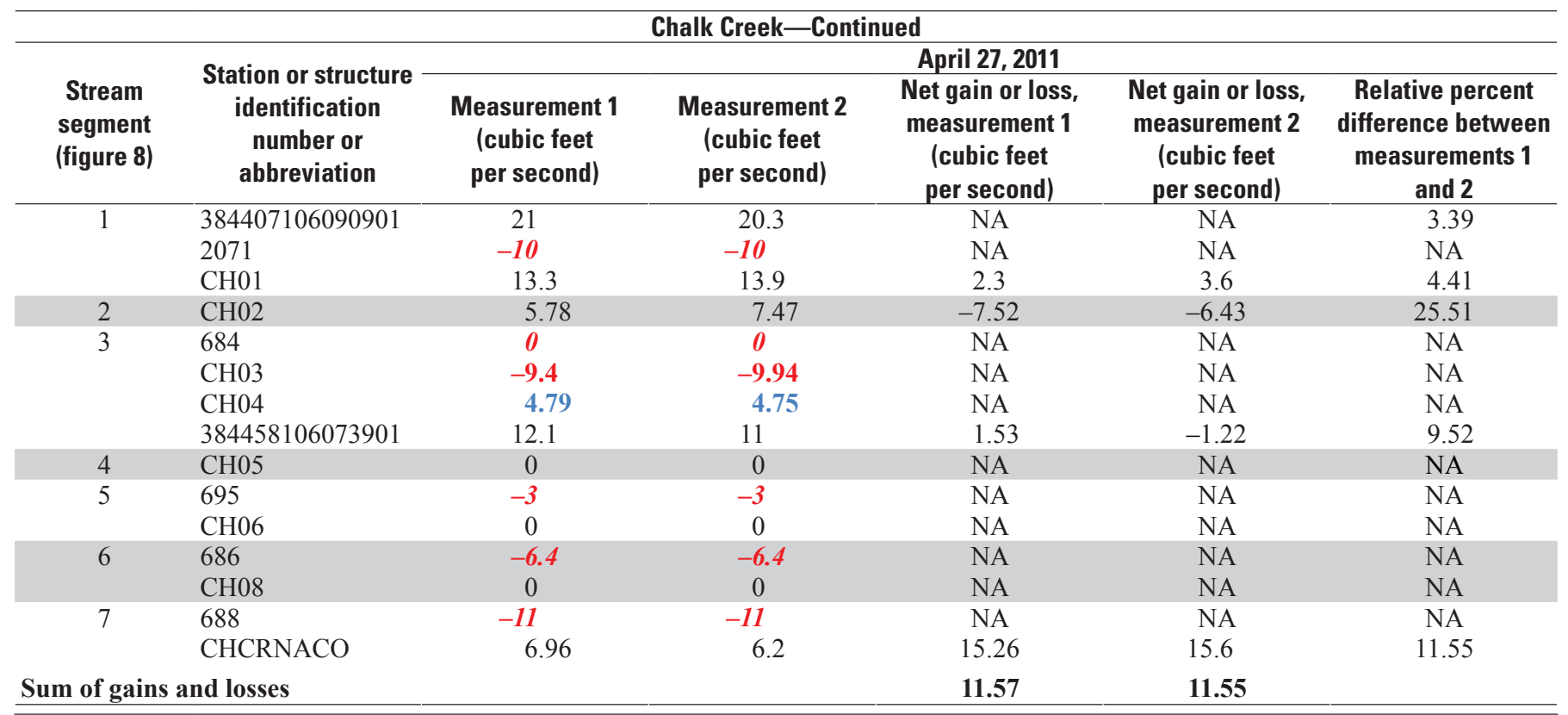

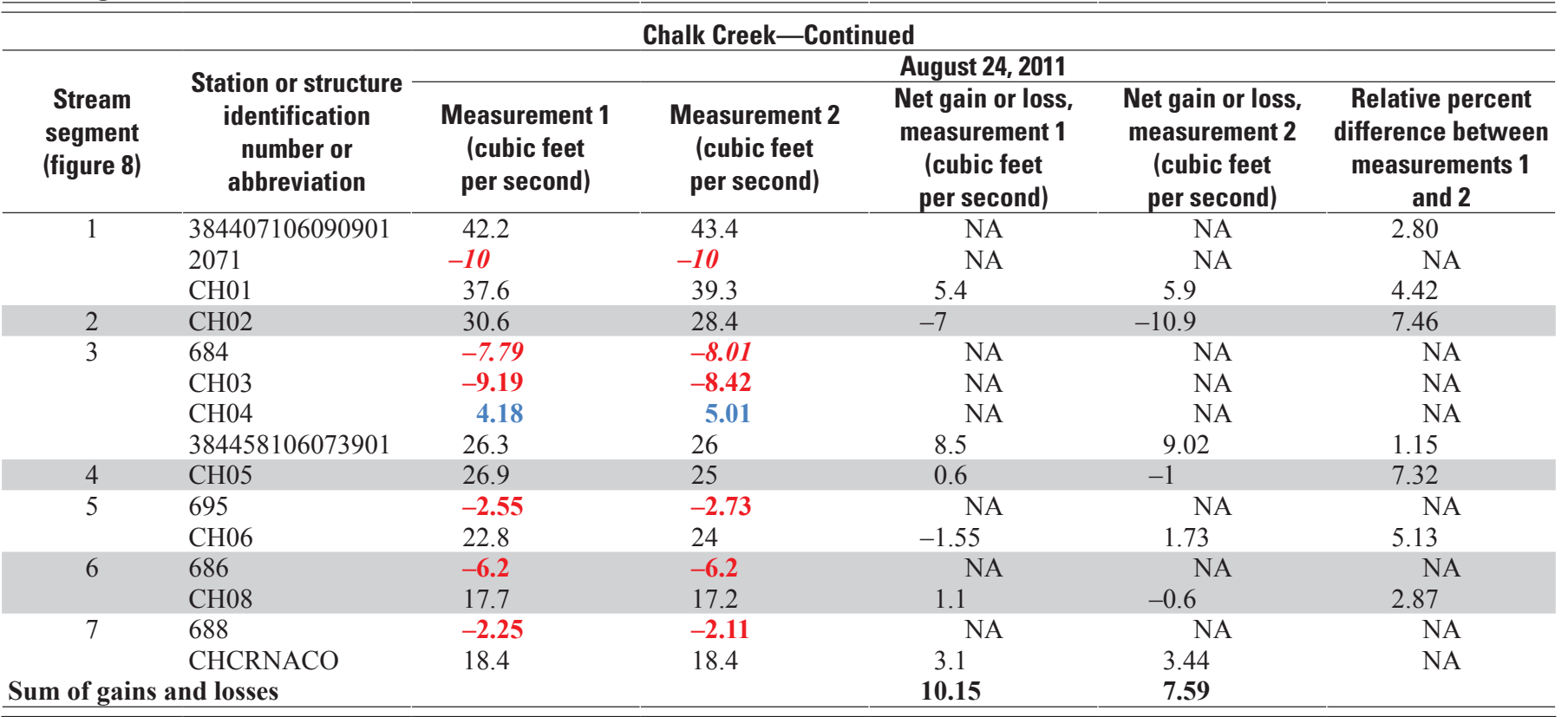


Table 1-1. Summary of synoptic measurements of Cottonwood, Chalk, and Browns Creeks and calculated gains and losses, August 9-11 and September 8-10, 2010, and April 27-29 and August 23-25, 2011.-Continued

[Station names are listed in table 2. Net gain is a positive value and net loss is a negative value; values in red are diversions; values in blue are tributary or seep inflow or return flow; italicized values are reported values; ${ }^{*}$, water diverted out of drainage basin; NA, not available]

\begin{tabular}{|c|c|c|c|c|c|c|}
\hline \multicolumn{7}{|c|}{ Browns Creek } \\
\hline \multirow[b]{2}{*}{$\begin{array}{c}\text { Stream } \\
\text { segment } \\
\text { (figure 9) }\end{array}$} & \multirow[b]{2}{*}{$\begin{array}{l}\text { Station or structure } \\
\text { identification } \\
\text { number or } \\
\text { abbreviation }\end{array}$} & \multicolumn{5}{|c|}{ August 11, 2010} \\
\hline & & $\begin{array}{l}\text { Measurement } 1 \\
\text { (cubic feet } \\
\text { per second) }\end{array}$ & $\begin{array}{c}\text { Measurement } 2 \\
\text { (cubic feet } \\
\text { per second) }\end{array}$ & $\begin{array}{c}\text { Net gain or loss, } \\
\text { measurement } 1 \\
\text { (cubic feet } \\
\text { per second) }\end{array}$ & $\begin{array}{c}\text { Net gain or loss, } \\
\text { measurement } 2 \\
\text { (cubic feet } \\
\text { per second) }\end{array}$ & $\begin{array}{c}\text { Relative percent } \\
\text { difference between } \\
\text { measurements } 1 \\
\text { and } 2 \\
\end{array}$ \\
\hline \multirow[t]{4}{*}{1} & 384100106065701 & 19.60 & 18.40 & NA & NA & 6.32 \\
\hline & 634 & 0.00 & $\mathbf{0 . 0 0}$ & NA & NA & NA \\
\hline & 789 & -1.3 & -1.3 & NA & NA & NA \\
\hline & $\mathrm{BC} 01$ & 14.90 & 14.50 & 5.18 & 5.53 & 2.72 \\
\hline \multirow[t]{2}{*}{2} & 629 & -2.5 & -2.27 & NA & NA & NA \\
\hline & $\mathrm{BC} 02$ & 15.00 & 16.00 & 2.60 & 3.77 & 6.45 \\
\hline \multirow[t]{2}{*}{3} & 1138 & -2.6 & -7.49 & NA & NA & NA \\
\hline & $\mathrm{BC} 03$ & 12.4 & 8.51 & 0 & 0 & 37.21 \\
\hline 6 & 384132106042701 & 14.5 & 11.9 & 6.09 & 2.20 & 19.70 \\
\hline \multirow[t]{2}{*}{7} & 825 & $\mathbf{0}$ & $\mathbf{0}$ & NA & NA & NA \\
\hline & 384148106034201 & 13.9 & 12.1 & -0.6 & 0.2 & 13.85 \\
\hline \multicolumn{4}{|c|}{ Sum of gains and losses } & 13.14 & 17.17 & \\
\hline
\end{tabular}

Sum of gains and losses

\begin{tabular}{|c|c|c|c|c|c|c|}
\hline \multicolumn{7}{|c|}{ Browns Creek一Continued } \\
\hline $\begin{array}{c}\text { Stream } \\
\text { segment } \\
\text { (figure 9) }\end{array}$ & $\begin{array}{l}\text { Station or structure } \\
\text { identification } \\
\text { number or } \\
\text { abbreviation }\end{array}$ & $\begin{array}{l}\text { Measurement } 1 \\
\text { (cubic feet } \\
\text { per second) }\end{array}$ & $\begin{array}{l}\text { Measurement } 2 \\
\text { (cubic feet } \\
\text { per second) }\end{array}$ & $\begin{array}{c}\text { Net gain or loss, } \\
\text { measurement } 1 \\
\text { (cubic feet } \\
\text { per second) }\end{array}$ & $\begin{array}{c}\text { Net gain or loss, } \\
\text { measurement } 2 \\
\text { (cubic feet } \\
\text { per second) }\end{array}$ & $\begin{array}{l}\text { Relative percent } \\
\text { difference between } \\
\text { measurements } 1 \\
\text { and } 2\end{array}$ \\
\hline \multirow[t]{4}{*}{1} & 384100106065701 & 6.26 & 6.28 & NA & NA & 0.32 \\
\hline & 634 & 0 & -0.31 & NA & NA & NA \\
\hline & 789 & $\mathbf{0}$ & $\mathbf{0}$ & NA & NA & NA \\
\hline & $\mathrm{BC} 01$ & 3.37 & 3.18 & 1.18 & 0.77 & 5.80 \\
\hline \multirow[t]{2}{*}{2} & 629 & -0.13 & -0.13 & NA & NA & NA \\
\hline & $\mathrm{BC} 02$ & 3.26 & 3.46 & 0.02 & 0.41 & 5.95 \\
\hline \multirow[t]{2}{*}{3} & 1138 & 0 & 0 & NA & NA & NA \\
\hline & $\mathrm{BC} 03$ & 0 & 0 & NA & NA & NA \\
\hline 6 & 384132106042701 & 3.98 & 3.42 & NA & NA & 15.14 \\
\hline \multirow[t]{2}{*}{7} & 825 & -1.63 & -1.9 & NA & NA & NA \\
\hline & 384148106034201 & 2.26 & 2.16 & -0.09 & 0.64 & 4.52 \\
\hline \multicolumn{4}{|c|}{ Sum of gains and losses } & 4.32 & 5.11 & \\
\hline
\end{tabular}


Table 1-1. Summary of synoptic measurements of Cottonwood, Chalk, and Browns Creeks and calculated gains and losses, August 9-11 and September 8-10, 2010, and April 27-29 and August 23-25, 2011.-Continued

[Station names are listed in table 2. Net gain is a positive value and net loss is a negative value; values in red are diversions; values in blue are tributary or seep inflow or return flow; italicized values are reported values; ${ }^{*}$, water diverted out of drainage basin; NA, not available]

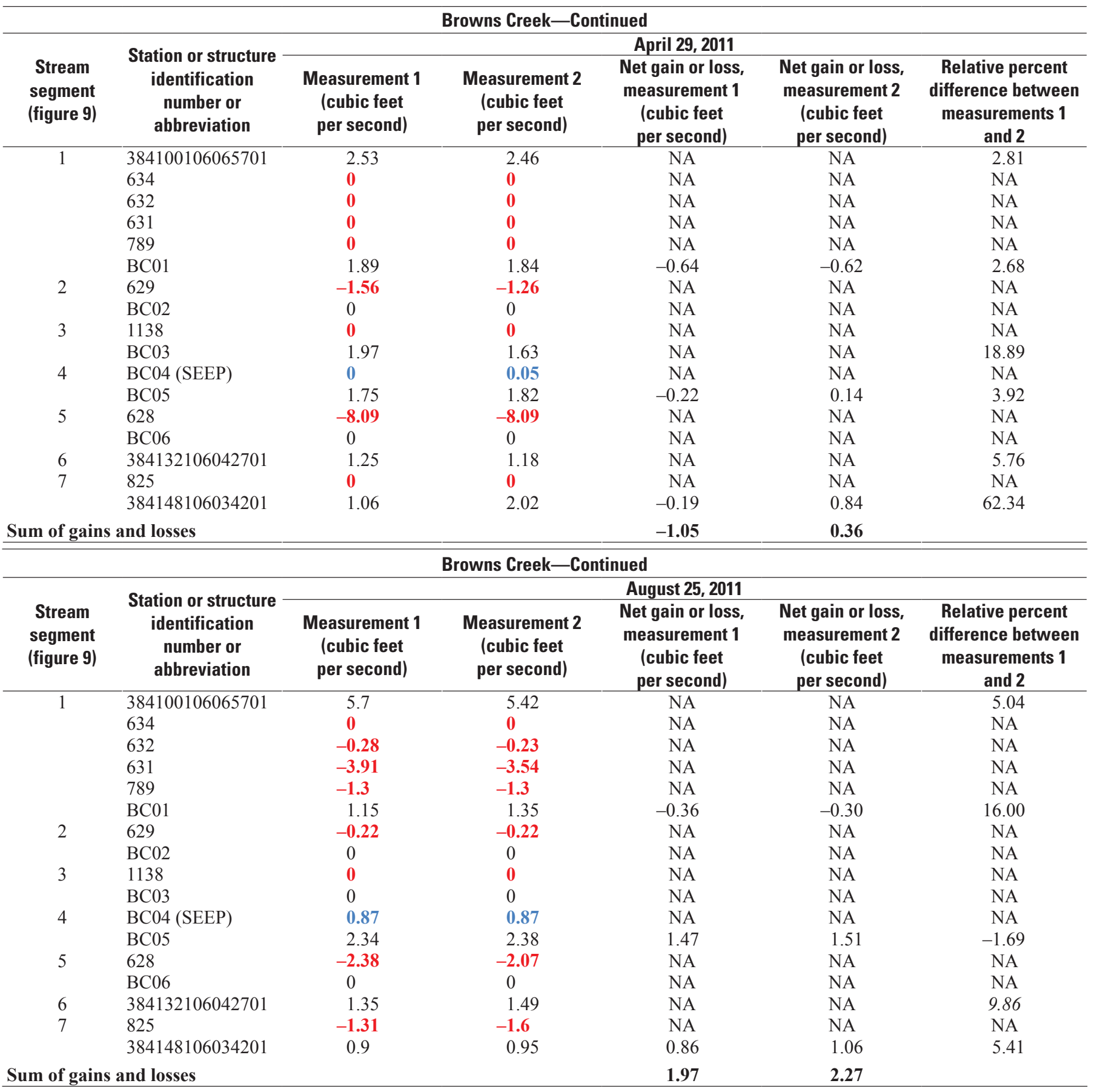


Table 1-2. Construction details for selected wells monitored or measured during 2010 and 2011 and selected wells with slug-test results.

[NAD83, North American Datum of 1983; NAVD88, North American Vertical Datum of 1988; Values in parentheses are depth intervals when more than one size of casing used in a well]

\begin{tabular}{|c|c|c|c|c|c|c|c|c|c|c|}
\hline $\begin{array}{c}\text { Site } \\
\text { identification } \\
\text { number }\end{array}$ & $\begin{array}{c}\text { Map } \\
\text { number } \\
\text { (figure 10) }\end{array}$ & $\begin{array}{c}\text { Latitude, } \\
\text { NAD83 } \\
\text { (decimal } \\
\text { degrees) }\end{array}$ & $\begin{array}{l}\text { Longitude, } \\
\text { NAD83 } \\
\text { (decimal } \\
\text { degrees) }\end{array}$ & $\begin{array}{c}\text { Altitude of land } \\
\text { surface at well } \\
\text { above NAVD88 } \\
\text { (feet) }\end{array}$ & Aquifer & $\begin{array}{l}\text { Well depth } \\
\text { (feet) }\end{array}$ & $\begin{array}{c}\text { Depth to } \\
\text { top of screen } \\
\text { intervals } \\
\text { (feet) }\end{array}$ & $\begin{array}{c}\text { Depth to } \\
\text { bottom of screen } \\
\text { interval } \\
\text { (feet) }\end{array}$ & $\begin{array}{l}\text { Casing } \\
\text { diameter } \\
\text { (inches) }\end{array}$ & $\begin{array}{r}\text { Slug test } \\
\text { (table 10) }\end{array}$ \\
\hline 383224106141601 & P11 & 38.540 & -106.238 & 8,736 & Alluvial-outwash & 105 & 60 & 105 & 6.625 & No \\
\hline 382939106002601 & P29 & 38.494 & -106.007 & 7,875 & Basin-fill & 400 & 100 & 400 & 4 & No \\
\hline 383016105571201 & $\mathrm{P} 47$ & 38.505 & -105.953 & 6,980 & Alluvial-outwash & 36 & 26 & 36 & 8 & No \\
\hline 383022106072901 & P49 & 38.506 & -106.125 & 7,881 & Basin-fill & 189 & 49 & 189 & 4.5 & No \\
\hline 383028106032701 & $\mathrm{P} 13$ & 38.508 & -106.058 & 7,483 & Basin-fill & 265 & 205 & 265 & 6 & No \\
\hline 383037105593701 & $\mathrm{~S} 29$ & 38.510 & -105.994 & 7,324 & Basin-fill & 220 & 150 & 220 & 6.625 & Yes \\
\hline 383038105593101 & P48 & 38.510 & -105.992 & 7,301 & Basin-fill & 320 & 280 & 320 & 6.625 & No \\
\hline 383116106043501 & $\mathrm{P} 21$ & 38.521 & -106.076 & 7,492 & Alluvial-outwash & 32 & 19 & 32 & 7 & No \\
\hline 383117106051901 & $\mathrm{C} 17$ & 38.521 & -106.089 & 7,569 & Alluvial-outwash & 29 & 9 & 29 & 2.5 & Yes \\
\hline 383138106020401 & $\mathrm{~S} 27$ & 38.527 & -106.035 & 7,263 & Alluvial-outwash & 40 & 20 & 40 & 6.675 & Yes \\
\hline 383140106023601 & $\mathrm{P} 28$ & 38.528 & -106.043 & 7,315 & Alluvial-outwash & 120 & 41 & 120 & 4.5 & No \\
\hline 383147106002701 & $\mathrm{P} 22$ & 38.530 & -106.008 & 7,132 & Alluvial-outwash & 61 & 31 & 61 & 6.5 & No \\
\hline 383153106063801 & S26 & 38.531 & -106.110 & 7,804 & Alluvial-outwash & 142 & 82 & 142 & $6.625(0-40)$ & Yes \\
\hline 383204106015401 & $\mathrm{~S} 25$ & 38.534 & -106.032 & 7,248 & Alluvial-outwash & 75 & 40 & 75 & $\begin{array}{c}4.5(22-82) \\
6(-1-20) \\
4(20-40)\end{array}$ & $\begin{array}{l}\text { No } \\
\text { Yes } \\
\text { No }\end{array}$ \\
\hline 383214106073201 & P25 & 38.537 & -106.126 & 7,925 & Alluvial-outwash & 57 & 36 & 57 & 6.625 & No \\
\hline 383235106111901 & $\mathrm{~S} 24$ & 38.543 & -106.189 & 8,283 & Alluvial-outwash & 130 & 80 & 130 & 7 & Yes \\
\hline 383251106070301 & P26 & 38.548 & -106.117 & 8,019 & Basin-fill & 65 & 48 & 65 & 6.625 & No \\
\hline 383256106060301 & P19 & 38.549 & -106.101 & 7,933 & Basin-fill & 300 & 180 & 300 & 4 & No \\
\hline 383303106012501 & $\mathrm{P} 43$ & 38.551 & -106.024 & 7,109 & Alluvial-outwash & 85 & 45 & 85 & 6.625 & No \\
\hline 383306106113401 & $\mathrm{P} 23$ & 38.552 & -106.193 & 8,459 & Alluvial-outwash & 65 & 45 & 65 & 5 & No \\
\hline 383342106032201 & $\mathrm{~S} 23$ & 38.562 & -106.056 & 7,191 & Alluvial-outwash & 65 & 45 & 65 & 6.625 & Yes \\
\hline 383359106030901 & $\mathrm{~S} 22$ & 38.566 & -106.052 & 7,167 & Alluvial-outwash & 160 & 80 & 160 & 6.625 & Yes \\
\hline 383422106022801 & P09 & 38.573 & -106.041 & 7,240 & Alluvial-outwash & 40 & 24 & 40 & 6.625 & No \\
\hline 383437106121301 & P07 & 38.577 & -106.204 & 8,981 & Basin-fill & 450 & 150 & 450 & 6.625 & No \\
\hline 383438106043901 & $\mathrm{C} 16$ & 38.577 & -106.077 & 7,190 & Alluvial-outwash & 37 & 7 & 33 & 2.5 & Yes \\
\hline 383443106041601 & $\mathrm{C} 15$ & 38.579 & -106.071 & 7,232 & Alluvial-outwash & 83.5 & 18.5 & 83.5 & 2.5 & Yes \\
\hline 383446106021701 & $\mathrm{C} 14$ & 38.579 & -106.038 & 7,286 & Alluvial-outwash & 70 & 40 & 70 & 2.5 & Yes \\
\hline 383541106033901 & $\mathrm{C} 13$ & 38.595 & -106.061 & 7,303 & Alluvial-outwash & 53 & 23 & 53 & 2.5 & Yes \\
\hline 383557106053401 & S17 & 38.599 & -106.093 & 7,418 & Basin-fill & 160 & 55 & 160 & 6.675 & Yes \\
\hline 383705106071601 & $\mathrm{P} 12$ & 38.618 & -106.121 & 7,943 & Basin-fill & 110 & 58 & 110 & 4.5 & No \\
\hline 383858106080601 & $\mathrm{P} 45$ & 38.649 & -106.135 & 8,632 & Basin-fill & 470 & 370 & 470 & 4.5 & No \\
\hline 383916106060501 & $\mathrm{~S} 16$ & 38.655 & -106.101 & 7,853 & Basin-fill & 70 & 40 & 70 & 6.5 & Yes \\
\hline 384027106084301 & P04 & 38.674 & -106.145 & 8,619 & Alluvial-outwash & 187 & 87 & 187 & 4.5 & No \\
\hline 384028106065101 & $\mathrm{P} 10$ & 38.674 & -106.114 & 8,260 & Basin-fill & 246 & 146 & 246 & 4.5 & No \\
\hline 384040106082101 & $\mathrm{~S} 15$ & 38.678 & -106.139 & 8,528 & Alluvial-outwash & 140 & 100 & 140 & 6.625 & Yes \\
\hline 384105106054301 & $\mathrm{P} 02$ & 38.685 & -106.095 & 7,992 & Basin-fill & 73 & 43 & 73 & 6.625 & No \\
\hline 384115106081601 & P16 & 38.688 & -106.138 & 8,448 & Basin-fill & 241 & 159 & 241 & 6.625 & No \\
\hline 384126106062901 & $\mathrm{C} 12$ & 38.691 & -106.108 & 8,089 & Alluvial-outwash & 58.3 & 8.3 & 58.3 & 2.5 & Yes \\
\hline 384134106042601 & $\mathrm{C} 11$ & 38.693 & -106.074 & 7,744 & Alluvial-outwash & 43.5 & 13.5 & 43.5 & 2.5 & Yes \\
\hline 384215106081901 & P44 & 38.704 & -106.139 & 8,275 & Alluvial-outwash & 174 & 89 & 174 & 4.5 & No \\
\hline
\end{tabular}


Table 1-2. Construction details for selected wells monitored or measured during 2010 and 2011 and selected wells with slug-test results. - Continued

[NAD83, North American Datum of 1983; NAVD88, North American Vertical Datum of 1988; Values in parentheses are depth intervals when more than one size of casing used in a well]

\begin{tabular}{|c|c|c|c|c|c|c|c|c|c|c|}
\hline $\begin{array}{c}\text { Site } \\
\text { identification } \\
\text { number }\end{array}$ & $\begin{array}{c}\text { Map } \\
\text { number } \\
\text { (figure 10) }\end{array}$ & $\begin{array}{l}\text { Latitude, } \\
\text { NAD83 } \\
\text { (decimal } \\
\text { degrees) }\end{array}$ & $\begin{array}{l}\text { Longitude, } \\
\text { NAD83 } \\
\text { (decimal } \\
\text { degrees) }\end{array}$ & $\begin{array}{c}\text { Altitude of land } \\
\text { surface at well } \\
\text { above NAVD88 } \\
\text { (feet) }\end{array}$ & Aquifer & $\begin{array}{l}\text { Well depth } \\
\text { (feet) }\end{array}$ & $\begin{array}{c}\text { Depth to } \\
\text { top of screen } \\
\text { intervals } \\
\text { (feet) }\end{array}$ & $\begin{array}{c}\text { Depth to } \\
\text { bottom of screen } \\
\text { interval } \\
\text { (feet) }\end{array}$ & $\begin{array}{l}\text { Casing } \\
\text { diameter } \\
\text { (inches) }\end{array}$ & $\begin{array}{l}\text { Slug test } \\
\text { (table 10) }\end{array}$ \\
\hline 384238106045001 & $\mathrm{C} 10$ & 38.710 & -106.081 & 7,721 & Alluvial-outwash & 28.5 & 8.5 & 28.5 & 2.5 & Yes \\
\hline 384251106065901 & $\mathrm{P} 24$ & 38.714 & -106.116 & 7,989 & Alluvial-outwash & 110 & 80 & 110 & 5.25 & No \\
\hline 384311106104301 & $\mathrm{P} 42$ & 38.720 & -106.179 & 8,320 & Alluvial-outwash & 400 & 45 & 400 & 4 & No \\
\hline 384340106041201 & $\mathrm{C} 09$ & 38.728 & -106.070 & 7,646 & Alluvial-outwash & 27.5 & 7.5 & 27.5 & 2.5 & Yes \\
\hline 384403106050801 & $\mathrm{C} 08$ & 38.734 & -106.085 & 7,755 & Alluvial-outwash & 29 & 9 & 29 & 2.5 & Yes \\
\hline 384410106035601 & $\mathrm{P} 50$ & 38.736 & -106.065 & 7,606 & Alluvial-outwash & 54 & 40 & 54 & 6.625 & No \\
\hline 384418106074601 & $\mathrm{P} 27$ & 38.738 & -106.129 & 8,023 & Basin-fill & 215 & 175 & 215 & 9.56 & No \\
\hline 384429106061601 & $\mathrm{C} 07$ & 38.741 & -106.105 & 7,842 & Alluvial-outwash & 38.5 & 8.5 & 38.5 & 2.5 & Yes \\
\hline 384453106083901 & P18 & 38.748 & -106.144 & 8,310 & Basin-fill & 460 & 320 & 460 & 4.5 & No \\
\hline 384557106061001 & $\mathrm{P} 17$ & 38.766 & -106.103 & 7,805 & Basin-fill & 145 & 105 & 145 & 5.5 & No \\
\hline 384631106074001 & $\mathrm{P} 15$ & 38.775 & -106.128 & 8,088 & Alluvial-outwash & 118 & 78 & 118 & 5.56 & No \\
\hline 384644106100501 & P35 & 38.779 & -106.168 & 8,416 & Basin-fill & 380 & 240 & 380 & 5 & No \\
\hline 384736106082501 & $\mathrm{C} 06$ & 38.793 & -106.140 & 8,070 & Alluvial-outwash & 29 & 9 & 29 & 2.5 & Yes \\
\hline 384828106095801 & $\mathrm{C} 05$ & 38.808 & -106.166 & 8,189 & Alluvial-outwash & 38.5 & 8.5 & 38.5 & 2.5 & Yes \\
\hline 384844106120301 & S06 & 38.812 & -106.201 & 8,392 & Alluvial-outwash & 120 & 70 & 120 & 6.625 & Yes \\
\hline 384849106070701 & P46 & 38.814 & -106.119 & 7,886 & Alluvial-outwash & 55 & 20 & 30 & 4 & No \\
\hline 384911106095701 & $\mathrm{C} 04$ & 38.820 & -106.166 & 8,151 & Alluvial-outwash & 29 & 9 & 29 & 2.5 & Yes \\
\hline 384926106112001 & $\mathrm{P} 41$ & 38.824 & -106.189 & 8,245 & Alluvial-outwash & 55 & 40 & 55 & 9.56 & No \\
\hline 384942106063901 & $\mathrm{P} 30$ & 38.828 & -106.111 & 7,886 & Alluvial-outwash & 120 & 80 & 120 & 6.625 & No \\
\hline 384942106081601 & $\mathrm{P} 31$ & 38.828 & -106.138 & 8,001 & Alluvial-outwash & 101 & 23 & 101 & 10.75 & No \\
\hline 385003106100601 & P05 & 38.834 & -106.168 & 8,107 & Alluvial-outwash & 100 & 70 & 100 & 8.625 & No \\
\hline 385029106120101 & $\mathrm{P} 40$ & 38.842 & -106.200 & 8,456 & Alluvial-outwash & 183 & 163 & 183 & 4.5 & No \\
\hline 385032106120401 & P39 & 38.842 & -106.201 & 8,485 & Alluvial-outwash & 183 & 163 & 183 & 4.5 & No \\
\hline 385042106125801 & P38 & 38.845 & -106.216 & 8,842 & Basin-fill & 300 & 157 & 300 & 4 & No \\
\hline 385111106110601 & P37 & 38.853 & -106.185 & 8,325 & Basin-fill & 250 & 200 & 250 & 4.5 & No \\
\hline 385112106090401 & P08 & 38.853 & -106.151 & 8,029 & Alluvial-outwash & 35 & 20 & 25 & 7 & No \\
\hline 385230106132601 & $\mathrm{P} 03$ & 38.875 & -106.224 & 8,940 & Alluvial-outwash & 124 & & & & No \\
\hline 385303106121001 & P34 & 38.884 & -106.203 & 8,595 & Basin-fill & 350 & 270 & 350 & 4.5 & No \\
\hline 385307106095101 & $\mathrm{C} 03$ & 38.885 & -106.164 & 8,135 & Alluvial-outwash & 49 & 9 & 49 & 2.5 & Yes \\
\hline 385348106111901 & S03 & 38.897 & -106.189 & 8,425 & Alluvial-outwash & 180 & 155 & 180 & 6.625 & Yes \\
\hline 385349106130601 & P06 & 38.897 & -106.218 & 9,048 & Alluvial-outwash & 147 & 127 & 147 & 6.625 & No \\
\hline 385358106091601 & P36 & 38.900 & -106.155 & 8,205 & Alluvial-outwash & 100 & 70 & 100 & 6.625 & No \\
\hline 385526106102801 & $\mathrm{P} 20$ & 38.924 & -106.174 & 8,295 & Alluvial-outwash & 95 & 72 & 95 & 6.625 & No \\
\hline 385605106105701 & $\mathrm{C} 02$ & 38.935 & -106.183 & 8,336 & Alluvial-outwash & 34 & 4 & 34 & 2.5 & Yes \\
\hline 385630106111901 & $\mathrm{P} 32$ & 38.942 & -106.189 & 8,328 & Alluvial-outwash & 40 & 25 & 40 & 7 & No \\
\hline 385820106122501 & $\mathrm{C} 01$ & 38.972 & -106.207 & 8,533 & Alluvial-outwash & 29 & 9 & 29 & 2.5 & Yes \\
\hline 390113106143301 & P14 & 39.020 & -106.243 & 8,880 & Alluvial-outwash & 191 & 111 & 191 & 4.5 & No \\
\hline 390345106165001 & P33 & 39.062 & -106.281 & 9,178 & Alluvial-outwash & 180 & 120 & 180 & 5.5 & No \\
\hline
\end{tabular}




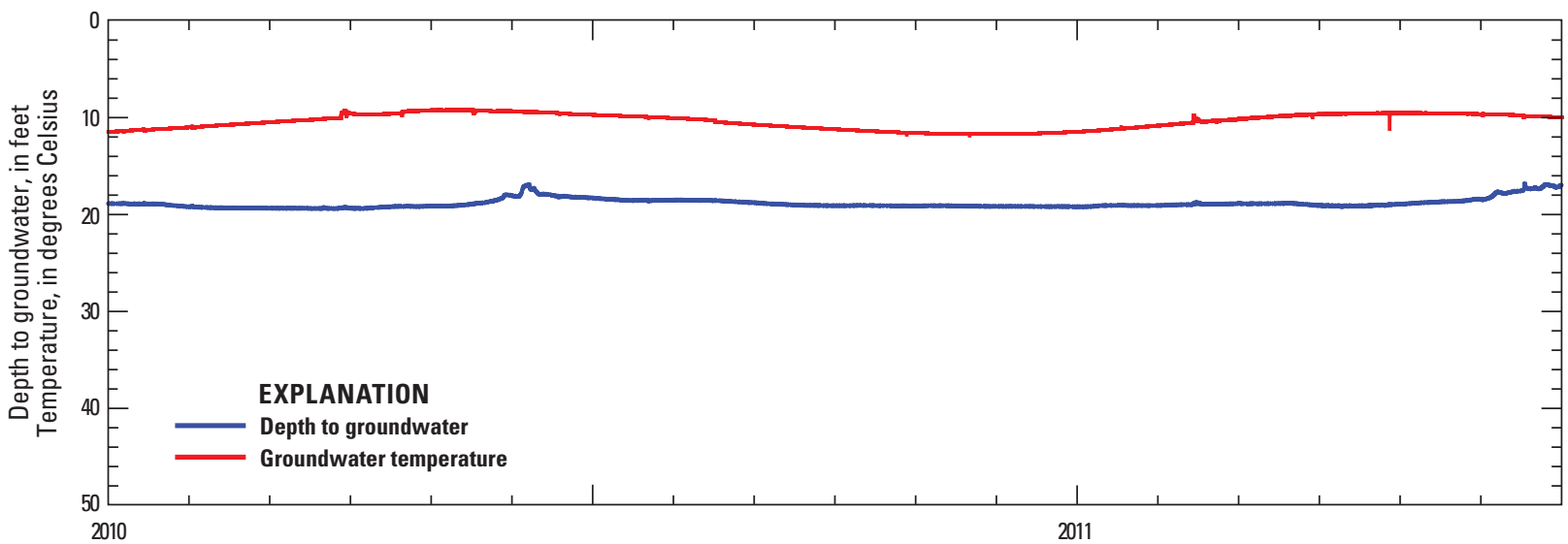

Figure 1-1. Depth to and temperature of groundwater in Colorado State University Department of Civil and Environmental Engineering monitoring well 127927_01 (U.S. Geological Survey 385820106122501), 2010 through June 2011. Location shown in figure 10, map label C01.

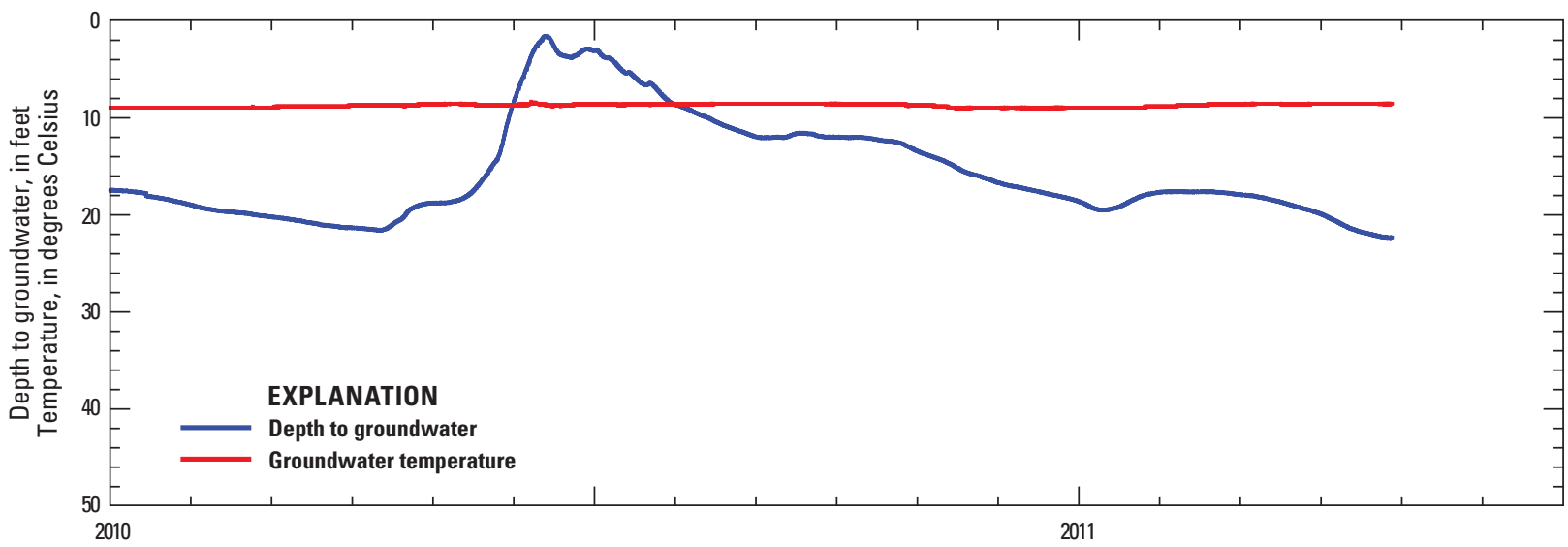

Figure 1-2. Depth to and temperature of groundwater in Colorado State University Department of Civil and Environmental Engineering monitoring well 137911_01 (U.S. Geological Survey 385605106105701), 2010 through April 28, 2011. Location shown in figure 10, map label C02.

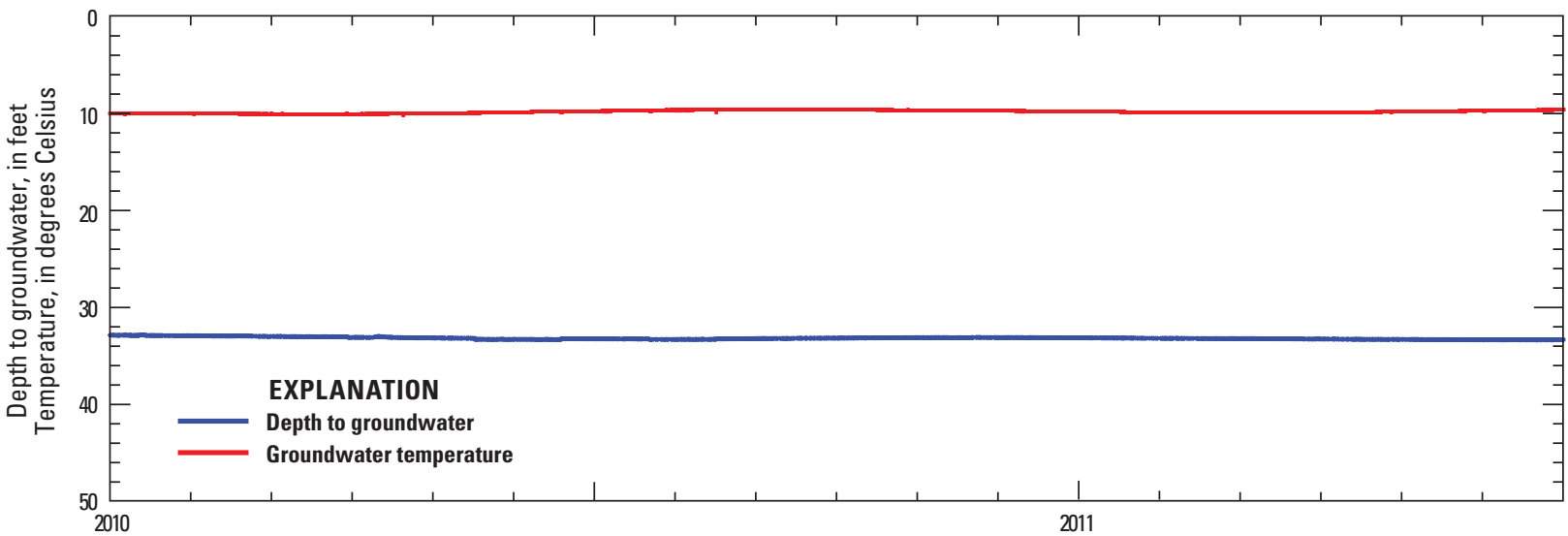

Figure 1-3. Depth to and temperature of groundwater in Colorado State University Department of Civil and Environmental Engineering monitoring well 137925_01 (U.S. Geological Survey 385307106095101), 2010 through June 2011. Location shown in figure 10, map label C03. 


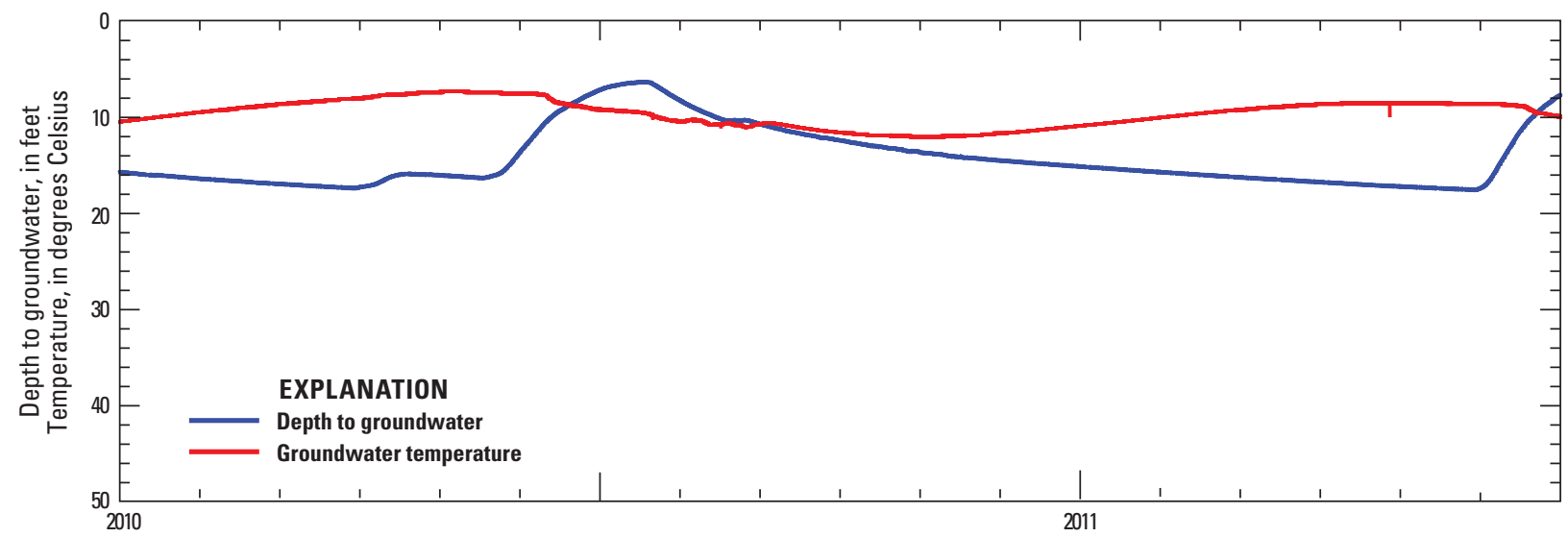

Figure 1-4. Depth to and temperature of groundwater in Colorado State University Department of Civil and Environmental Engineering monitoring well 147924_01 (U.S. Geological Survey 384911106095701), 2010 through June 2011. Location shown in figure 10, map label C04.

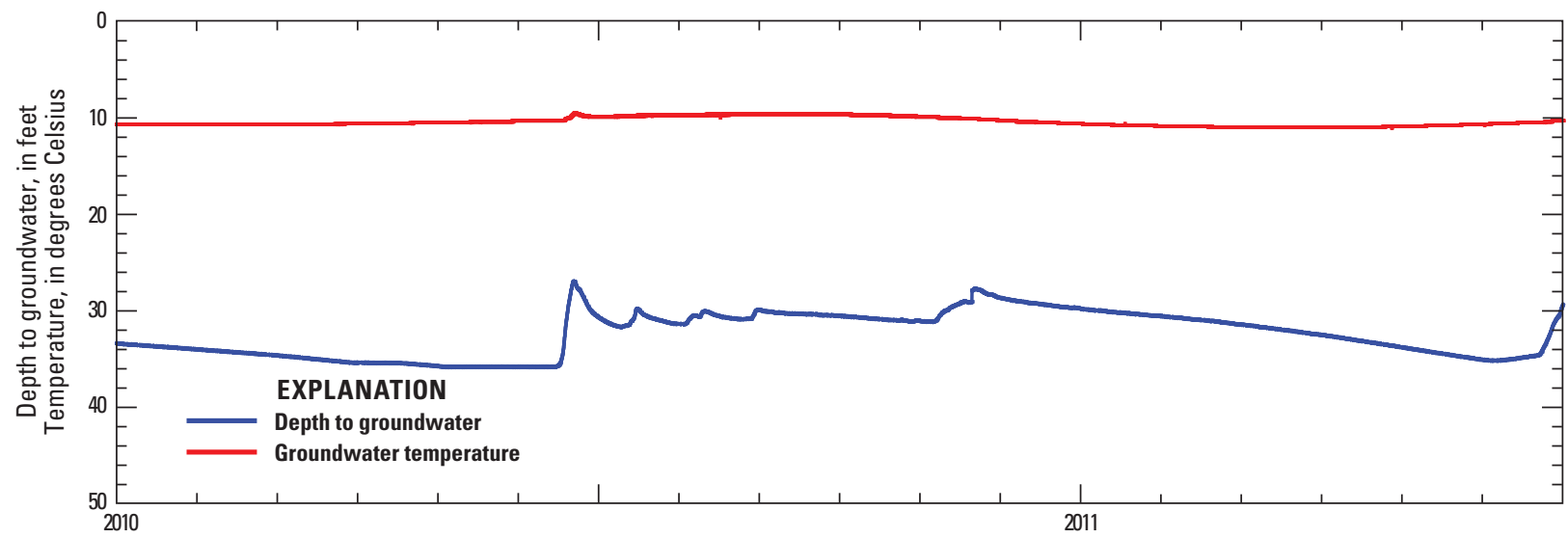

Figure 1-5. Depth to and temperature of groundwater in Colorado State University Department of Civil and Environmental Engineering monitoring well 147925_01 (U.S. Geological Survey 384828106095801), 2010 through June 2011. Location shown in figure 10, map label C05.

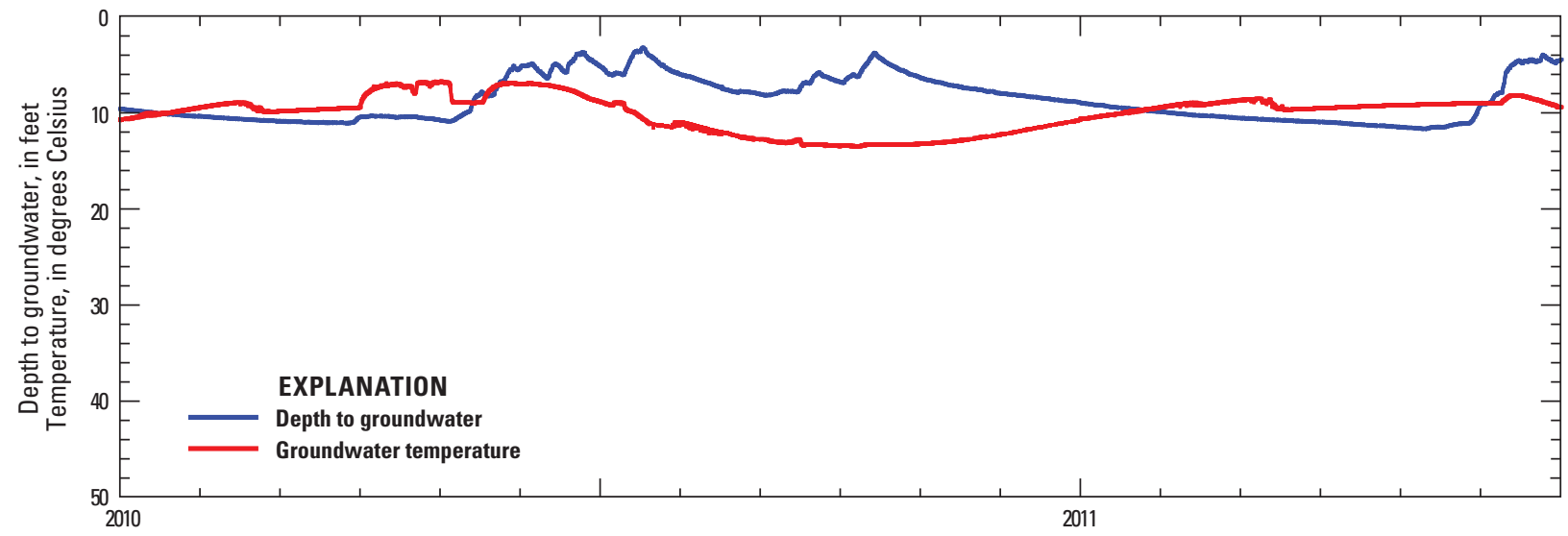

Figure 1-6. Depth to and temperature of groundwater in Colorado State University Department of Civil and Environmental Engineering monitoring well 147832_01 (U.S. Geological Survey 384736106082501), 2010 through June 2011. Location shown in figure 10, map label C06. 


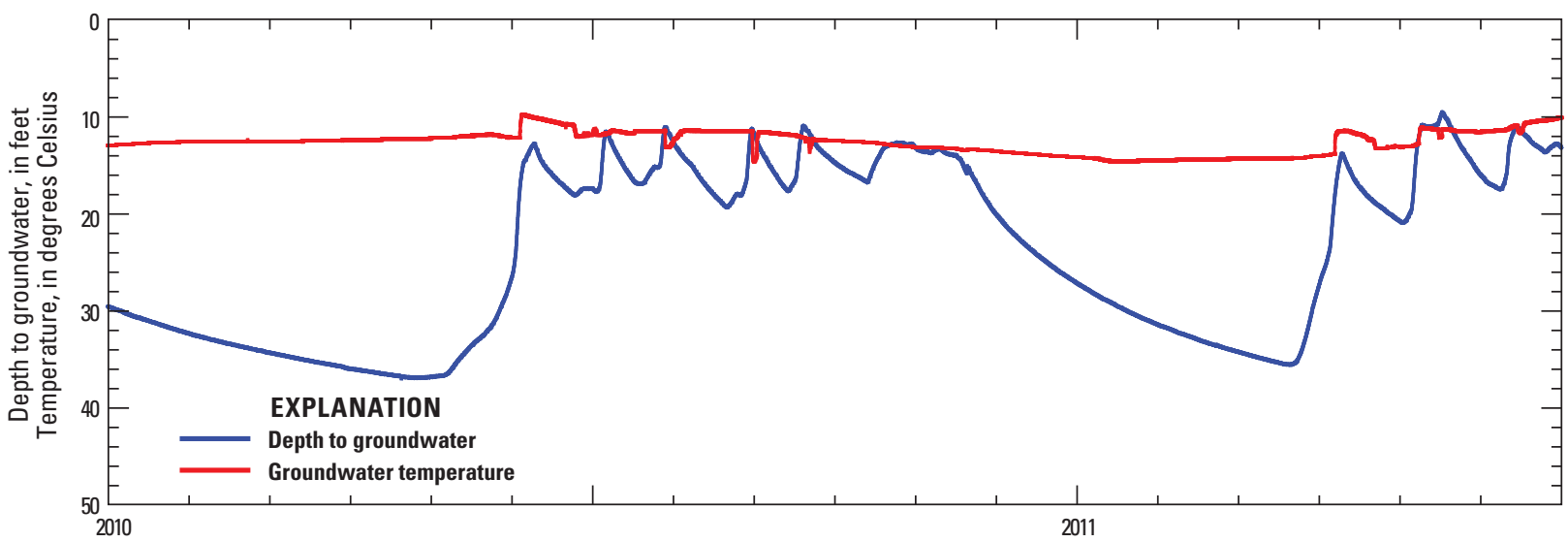

Figure 1-7. Depth to and temperature of groundwater in Colorado State University Department of Civil and Environmental Engineering monitoring well 157815_01 (U.S. Geological Survey 384429106061601), 2010 through June 2011. Location shown in figure 10, map label C07.

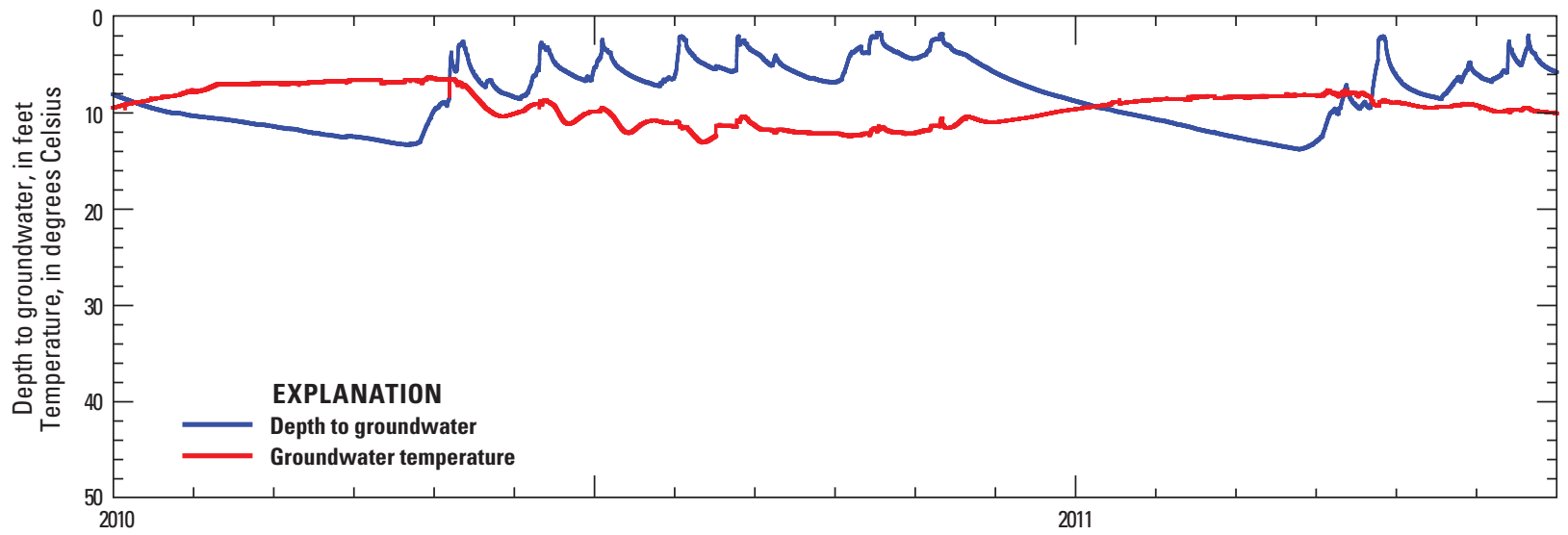

Figure 1-8. Depth to and temperature of groundwater in Colorado State University Department of Civil and Environmental Engineering monitoring well 157823_01 (U.S. Geological Survey 384403106050801), 2010 through June 2011. Location shown in figure 10, map label C08.

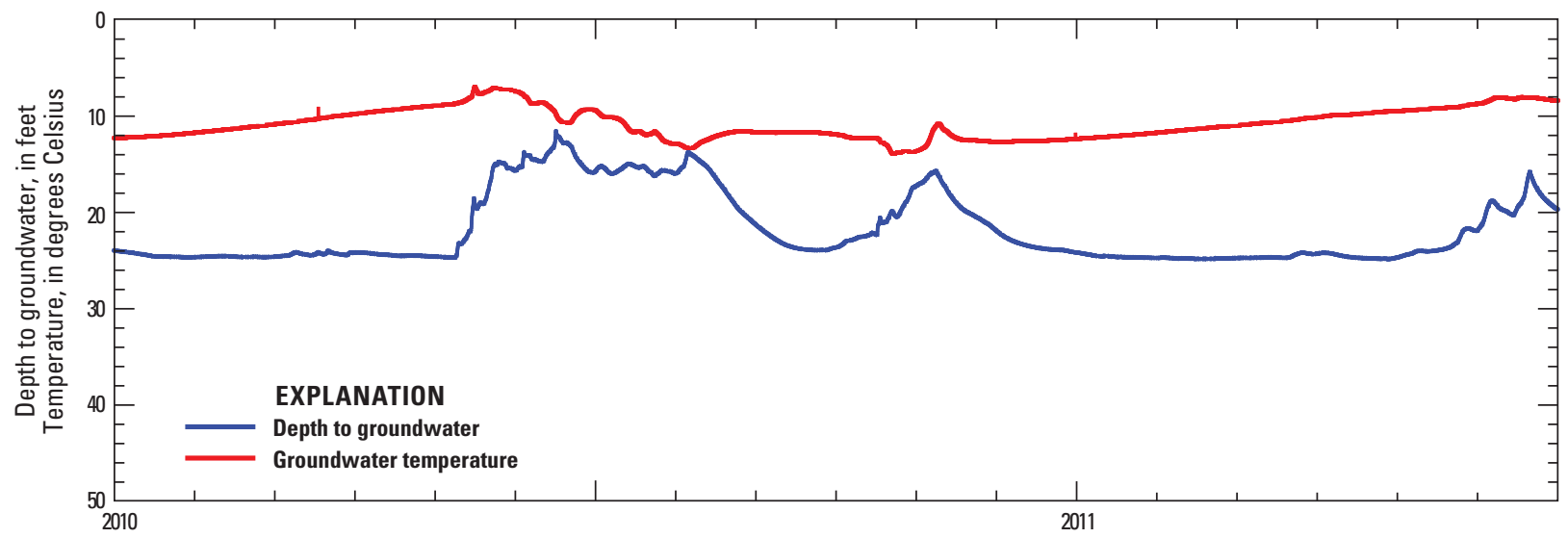

Figure 1-9. Depth to and temperature of groundwater in Colorado State University Department of Civil and Environmental Engineering monitoring well 157824_01 (U.S. Geological Survey 384340106041201), 2010 through June 2011. Location shown in figure 10, map label C09. 


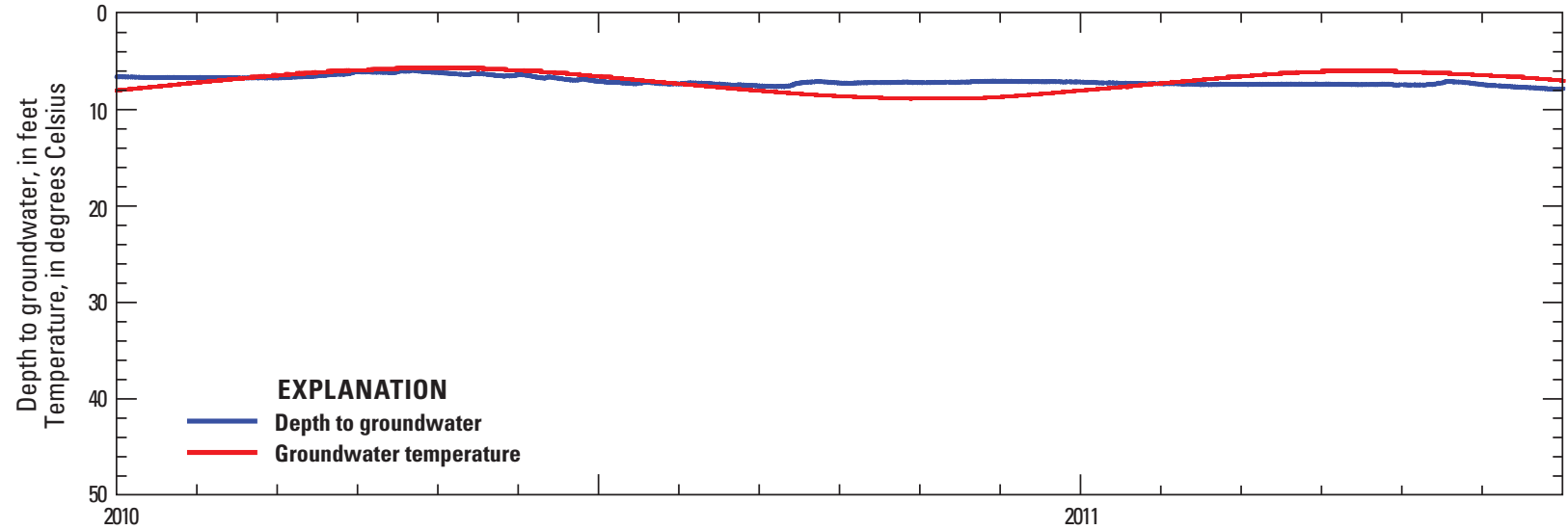

Figure 1-10. Depth to and temperature of groundwater in Colorado State University Department of Civil and Environmental Engineering monitoring well 157826_01 (U.S. Geological Survey 384238106045001), 2010 through June 2011. Location shown in figure 10 , map label C10.

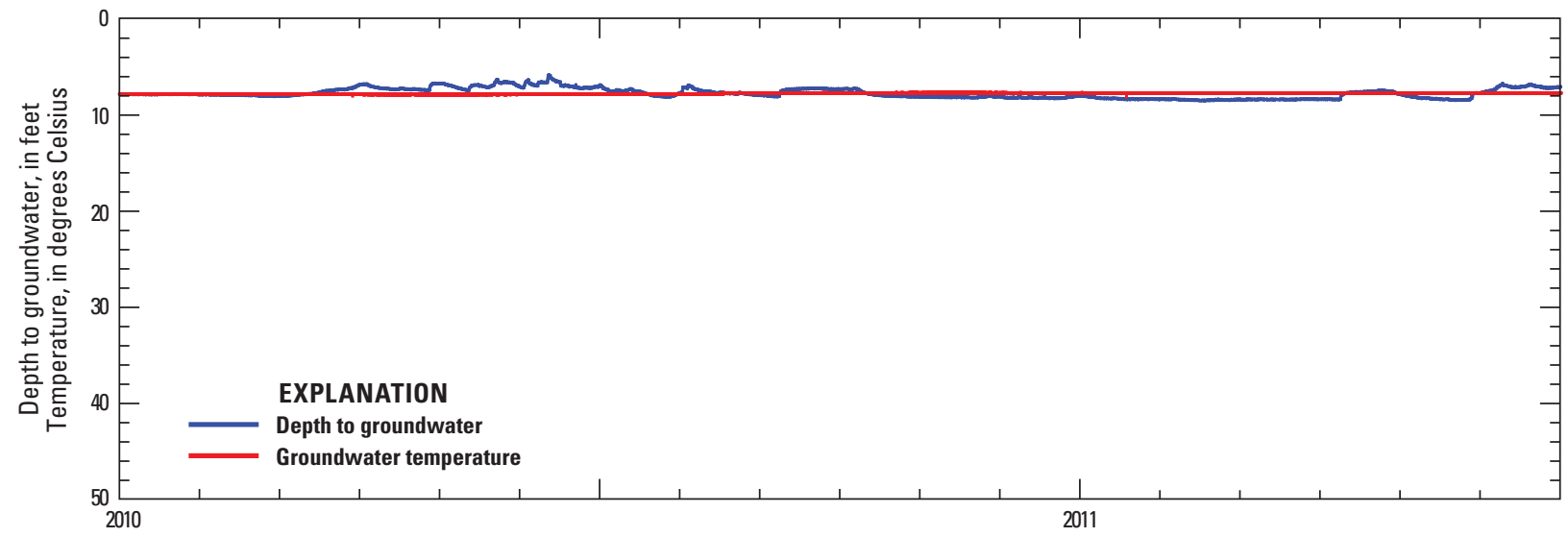

Figure 1-11. Depth to and temperature of groundwater in Colorado State University Department of Civil and Environmental Engineering monitoring well 510810 _01 (U.S. Geological Survey 384134106042601), 2010 through June 2011. Location shown in figure 10, map label C11.

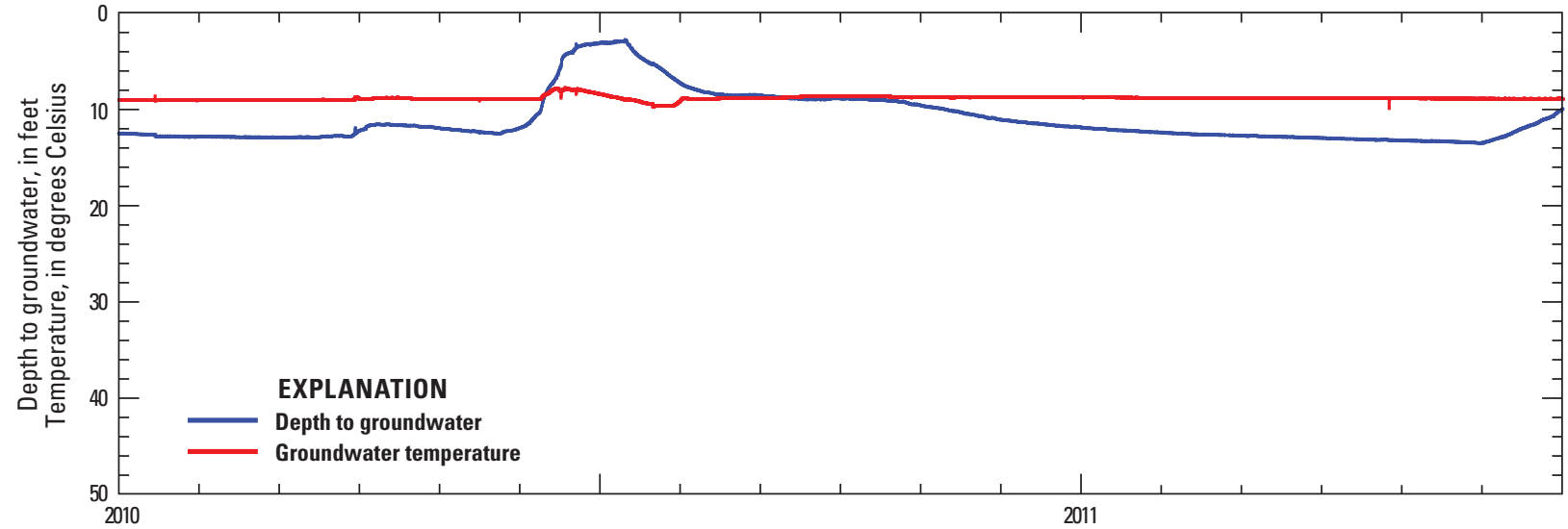

Figure 1-12. Depth to and temperature of groundwater in Colorado State University Department of Civil and Environmental Engineering monitoring well 510808 _01 (U.S. Geological Survey 384126106062901), 2010 through June 2011. Location shown in figure 10, map label $\mathrm{C} 12$. 


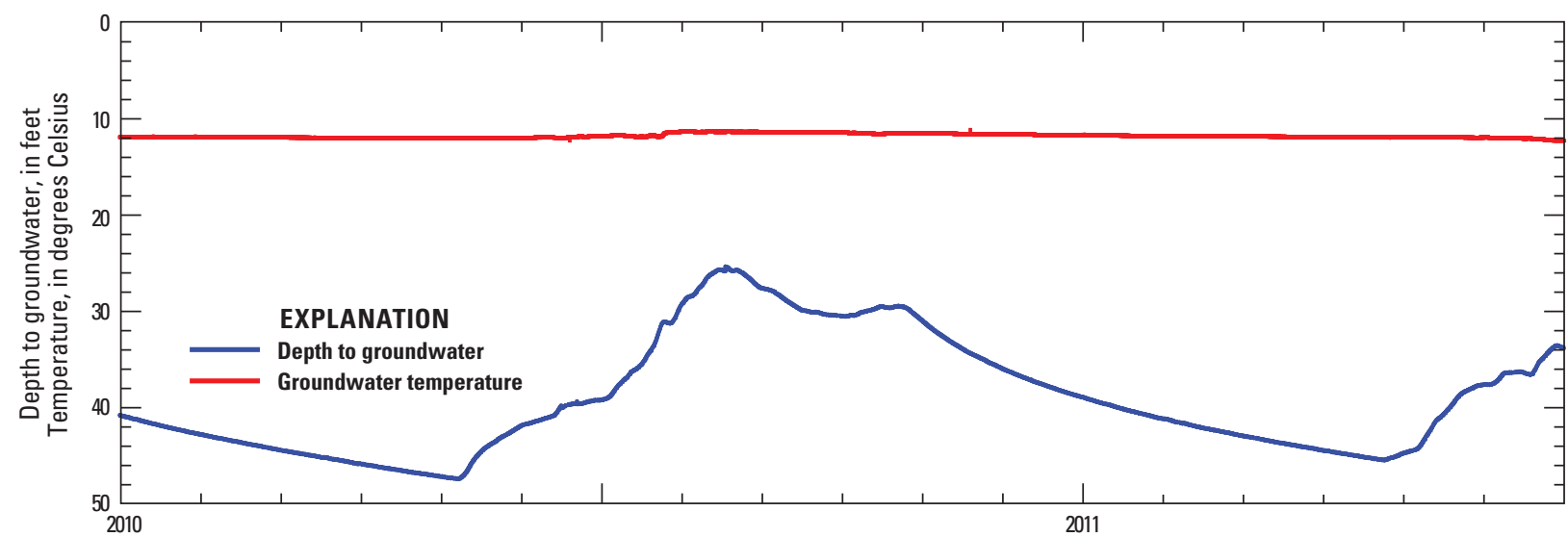

Figure 1-13. Depth to and temperature of groundwater in Colorado State University Department of Civil and Environmental Engineering monitoring well 500811_01 (U.S. Geological Survey 383541106033901), 2010 through June 2011. Location shown in figure 10, map label C13.

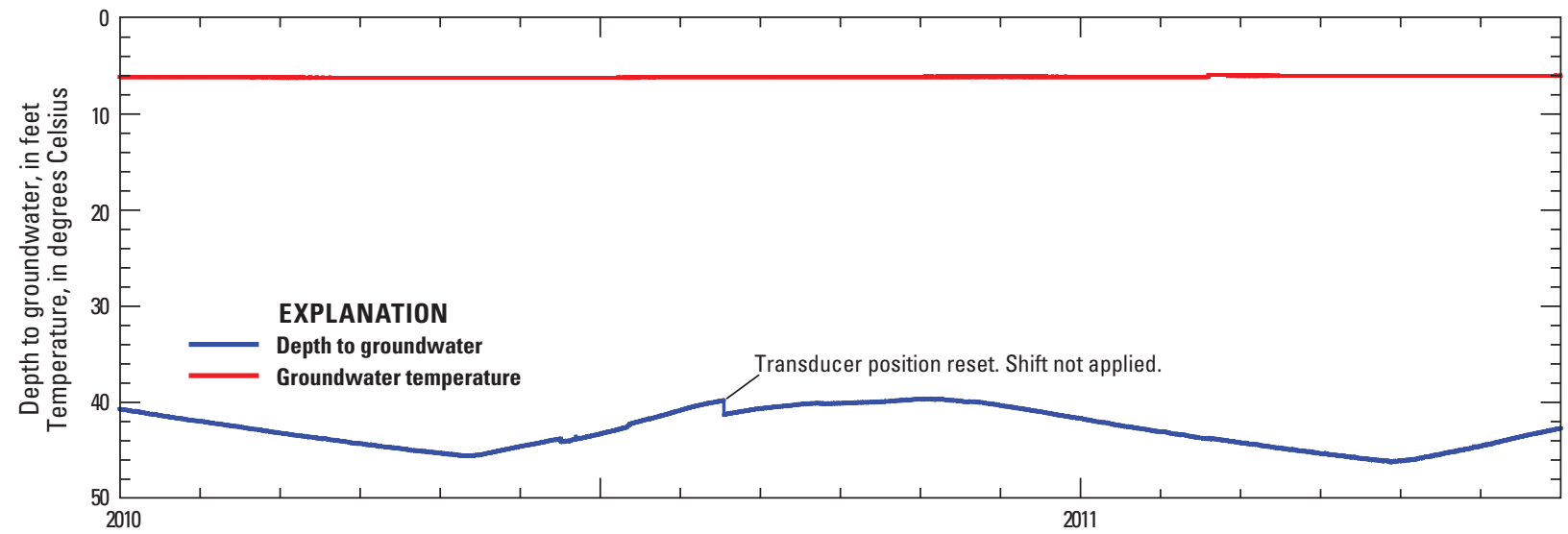

Figure 1-14. Depth to and temperature of groundwater in Colorado State University Department of Civil and Environmental Engineering monitoring well 500813_01 (U.S. Geological Survey 383446106021701), 2010 through June 2011. Location shown in figure 10, map label C14.

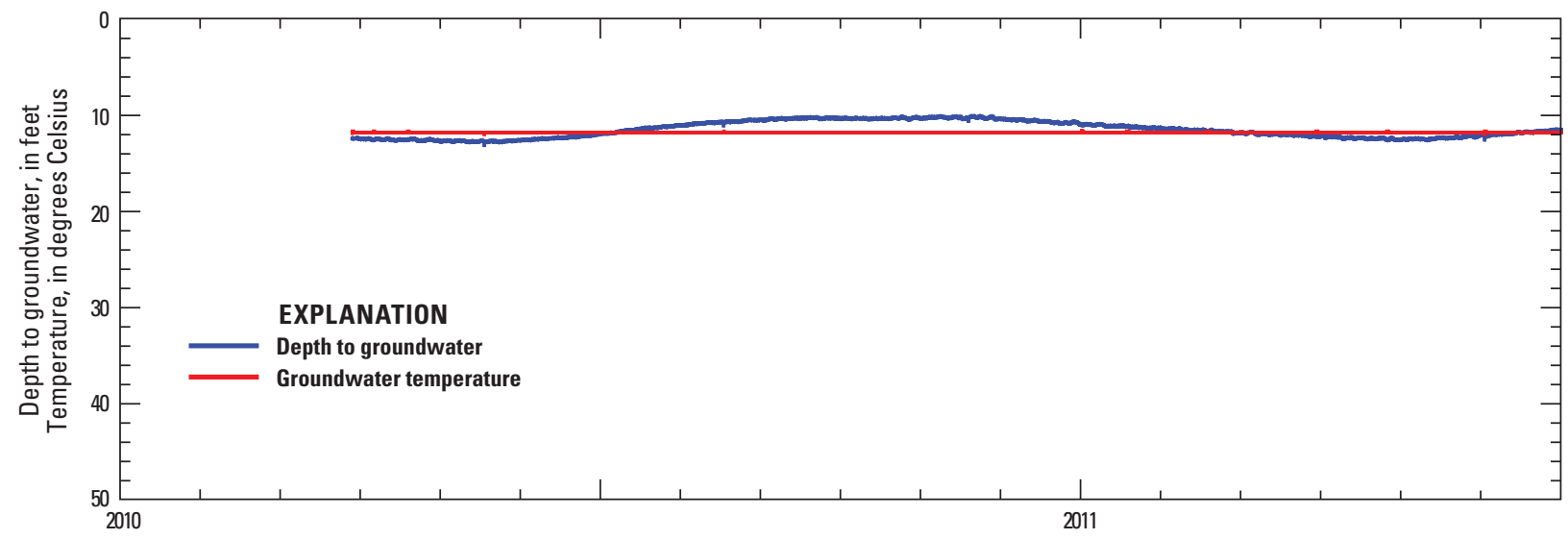

Figure 1-15. Depth to and temperature of groundwater in Colorado State University Department of Civil and Environmental Engineering monitoring well 500822_02 (U.S. Geological Survey 383443106041601), March 20, 2010 through June 2011. Location shown in figure 10, map label C15. 


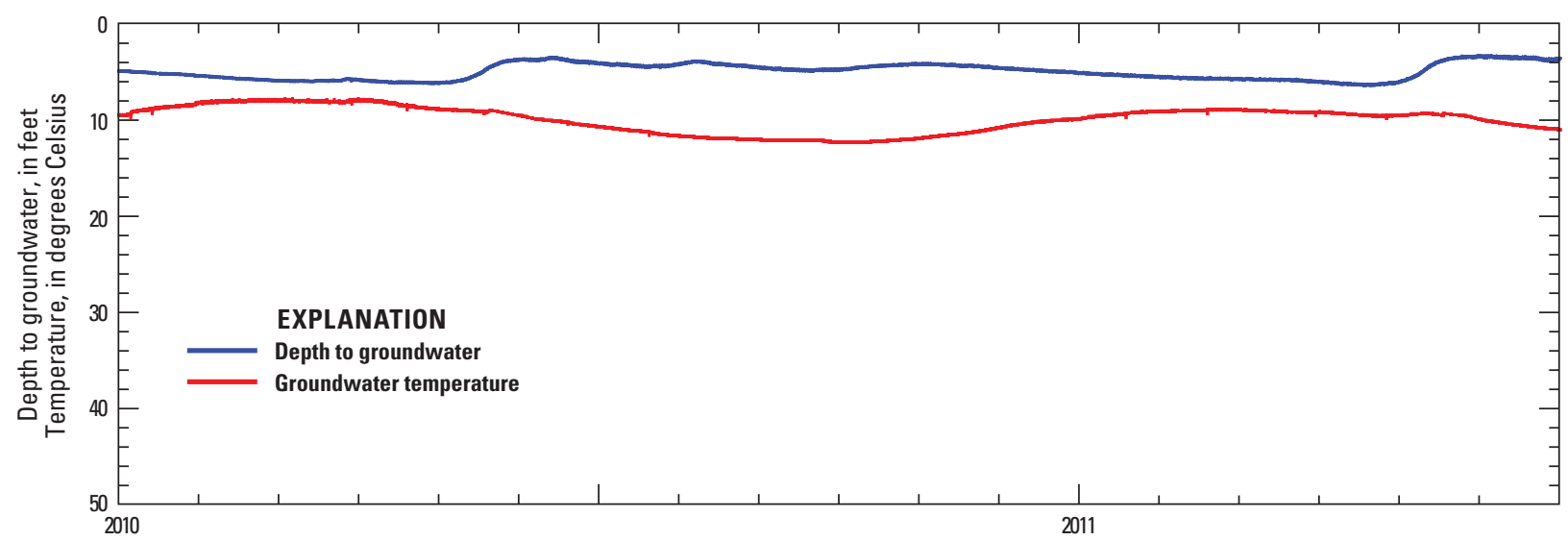

Figure 1-16. Depth to and temperature of groundwater in Colorado State University Department of Civil and Environmental Engineering monitoring well 500822_01 (U.S. Geological Survey 383438106043901), 2010 through June 2011. Location shown in figure 10, map label C16.

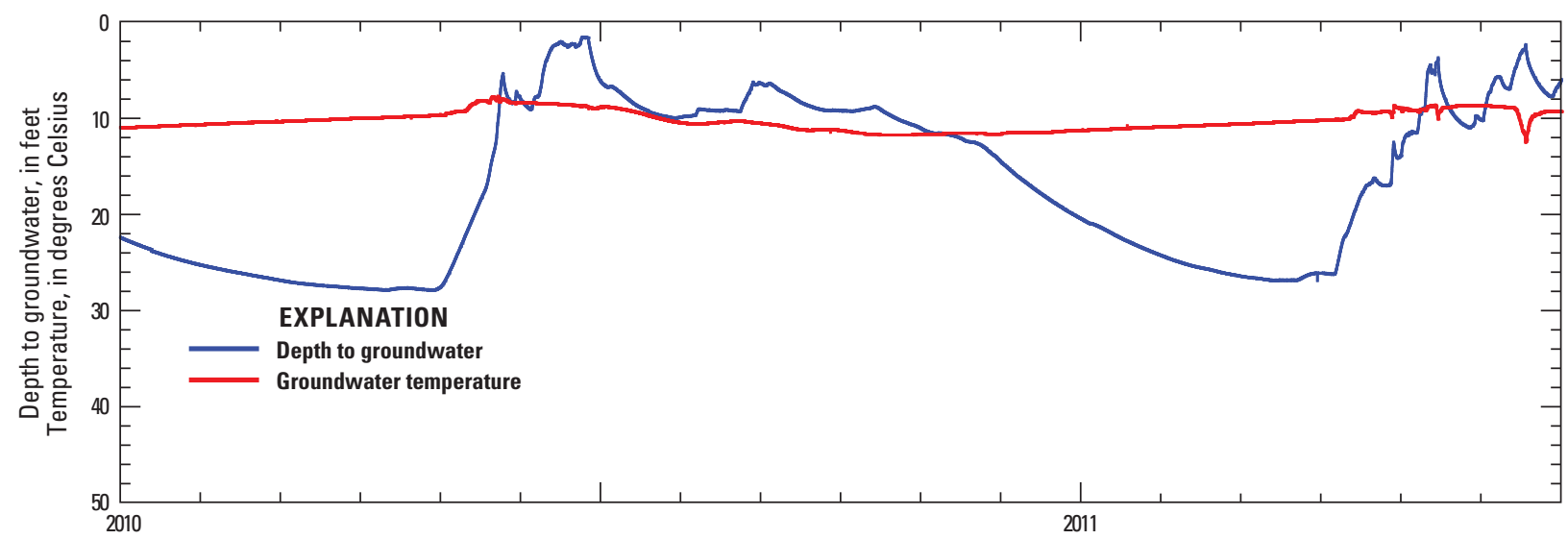

Figure 1-17. Depth to and temperature of groundwater in Colorado State University Department of Civil and Environmental Engineering monitoring well 490804_01 (U.S. Geological Survey 383117106051901), 2010 through April 28, 2011. Location shown in figure 10, map label C17.

Publishing support provided by:

Denver Publishing Service Center, Denver, Colorado

For more information concerning this publication, contact:

Director, USGS Colorado Water Science Center

Box 25046, Mail Stop 415

Denver, C0 80225

(303) 236-4882

Or visit the Colorado Water Science Center Web site at:

http://co.water.usgs.gov/

This publication is available online at:

http://dx.doi.org/10.3133/sir20145095 
